\title{
Mesozoic strata of Kong Karls Land, Svalbard, Norway; a link to the northern Barents Sea basins and platforms
}

\author{
Snorre Olaussen', Geir Birger Larssen², William Helland-Hansen 3,1, Erik P. Johannessen", \\ Arvid Nøttvedt ${ }^{5}$, Fridtjof Riis 6 , Biarte Rismyhr ${ }^{3,1}$, Morten Smelror ${ }^{7}$ \& David Worsley ${ }^{8}$
}

${ }^{1}$ Department of Arctic Geology, University Centre in Svalbard UNIS, 9171 Longyearbyen, Norway.

${ }^{2}$ Lundin Norway AS, NO-9405 Harstad, Norway.

${ }^{3}$ Department of Earth Science, University of Bergen, Allégaten 41, 5007 Bergen, Norway.

${ }^{4} E P$ Skolithos, 4022 Stavanger, Norway.

${ }^{5}$ Christian Michelsen Research AS, 5892 Bergen, Norway.

${ }^{6}$ Norwegian Petroleum Directorate, 4003 Stavanger, Norway.

${ }^{7}$ Geological Survey of Norway, P.O. Box 6215 Sluppen, NO-7491 Trondheim, Norway.

${ }^{8} \mathrm{PRW}$ Geoconsultants, 3475 Seetre, Norway.

E-mail corresponding author (Snorre Olaussen): snorre.olaussen@unis.no

Kong Karls Land, easternmost in the Svalbard archipelago, displays a $300 \mathrm{~m}$-thick Upper Triassic (Norian) to Lower Cretaceous (Aptian) succession. The islands are situated within a set of large-scale, NE-SW-trending folds. The sediments are poorly consolidated as a result of relatively shallow burial. Lower Cretaceous plateau lavas and sills cap the islands and have protected older strata from extensive Pliocene and Pleistocene erosion. Correlation between onland exposures and subsea seismic units shows that Kong Karls Land is a key reference area for the Late Triassic to Early Cretaceous development of the northern Barents Sea shelf, but also to the southwestern Barents Sea. The unique exposed succession can be correlated with nearby offshore data, enabling the recognition of key sequence stratigraphic surfaces which define major tectonic events. These enable subdivision of the succession into six tectonic megasequences (TMS 1 to TMS 6) of latest Permian to Early Cretaceous age. The TMS 1 is linked to denudation of the Uralian orogen and includes most of the northwestward prograding Triassic coastline in the northwestern Barents Sea and eastern part of Svalbard. The $200 \mathrm{~m}$-thick estuarine to shoreface deposits of the Rhaetian to Pliensbachian TMS 2 in Kong Karls Land stands in contrast to the 5 to $20 \mathrm{~m}$-thick condensed succession with numerous hiatuses in western Spitsbergen. This significant difference is suggested to be a response to an evolving foreland basin linked to the northern Barents Sea Basin and Novaya Zemlya Fold and Thrust Belt. The four youngest tectonic megasequences are represented by only thin remnants onshore and on the adjacent platform. Outcrop mapping and seismic profiles show high-amplitude weak folding in the Late Jurassic followed by Early Cretaceous reactivation, prior to deposition of the Helvetiafjellet Formation. The volcanism in Kong Karls Land is related to the High Arctic Large Igneous Province and opening of the Amerasian Basin, which resulted in uplift of the northern Barents Shelf and southwards tilting of the Svalbard Platform..

Keywords: Upper Triassic, Jurassic, Lower Cretaceous, Wilhelmøya Subgroup, Adventdalen Subgroup, facies analysis, basin development, tectonic events, sequence stratigraphy, volcanism, onshore offshore link, paleogeography.

Received 17. July 2018 / Accepted 16. December 2018 / Published online 5. March 2019

\section{Introduction}

The Barents Sea extends from Novaya Zemlya in the east to the North Atlantic continental margin in the west, from the Svalbard and Franz Josef Land archipelagos in the north, to the northern coasts of Norway and Russia in the south (Fig. 1). The Barents Sea is an intracratonic basin bounded by the Norwegian Greenland Sea and Eurasian basins on its western and northern flanks (Gudlaugsson et al., 1998; Ritzman \& Jokat, 2003; Faleide et al., 2008; Smelror et al., 2009).

Kong Karls Land comprises a group of three main islands and many smaller ones and constitutes the easternmost part of the Svalbard archipelago in the northwestern

Olaussen, S., Larssen, G.B., Helland-Hansen, W., Johannessen, E.P., Nøttvedt, A., Riis, F., Rismyhr, B., Smelror, M. \& Worsley, D. 2018: Mesozoic strata of Kong Karls Land, Svalbard, Norway; a link to the northern Barents Sea basins and platforms. Norwegian Journal of Geology 98, 1-69. https://dx.doi.org/10.17850/njg98-4-06. 

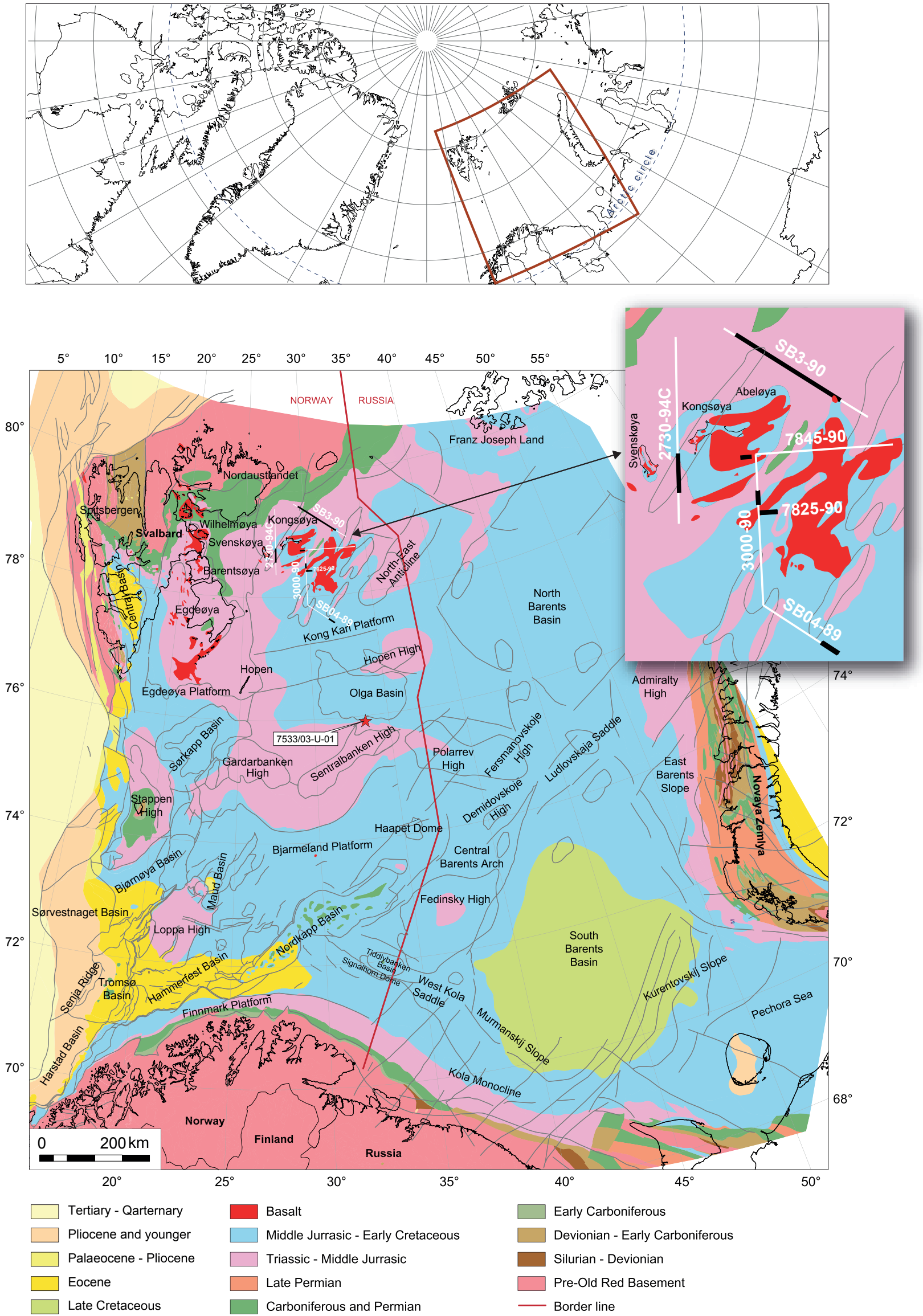

Figure 1. Simplified geological map of the greater Barents Sea area showing major tectonic elements and the subcrop beneath the Plio-/ Pleistocene sediments. Modified from Sigmond, 1992. The Inset shows Kong Karls Land and surrounding waters and shows the positions of seismic lines in Figs. 5, 6, 7, 25 \& 38 (black segment lines). 
corner of the Norwegian Barents Sea between 78 $30^{\prime}$ and $78^{\circ} \mathrm{N}$ and $26^{\circ}$ and $31^{\circ} \mathrm{E}$ (Fig. 1). The sedimentary outcrops are mainly confined to the two main islands, Kongsøya and Svenskøya (Fig. 2). These islands are capped by volcanic rocks, which also crop out on islets and skerries in the surrounding shallow shelf areas. Svenskøya is the westernmost island, $21 \mathrm{~km}$ by $7.5 \mathrm{~km}$. The central main island, Kongsøya, is about $40 \mathrm{~km}$ by $8 \mathrm{~km}$, and the eastern island, Abeløya, is only $4 \mathrm{~km}$ across, mostly less than 5 $\mathrm{m}$ above sea level and consisting of dolerite. The islands form some of the most remote parts of Svalbard, and the surrounding sea is covered by ice most of the year. Due to the isolated nature of these islands and environmental protection as the main breeding area of polar bears, the geology is far less studied than that of the main islands of the Svalbard archipelago.

Geological expeditions were arranged to Kong Karls Land by Statoil in 1984 and in 1992 by the Norwegian Petroleum Directorate (NPD) together with the companies Norsk Hydro, Saga Petroleum and Statoil. The aim of these two expeditions was to conduct detailed studies of the geology of the islands and to integrate the results with ongoing studies of the Barents Shelf. The results from these two Norwegian expeditions have been restricted until now. However, the data were made available to the Stratigraphic Committee of Svalbard in their reappraisal of the post-Caledonian stratigraphy of the archipelago (Dallmann et al., 1999).

Volcanic/basaltic rocks capping the islands have prevented erosion of the poorly consolidated or loose older sandstone and mudstone successions. Correlation between units exposed on land and seismic units below the seabed, and the thicker and more complete stratigraphy compared to the rest of Svalbard, make Kong Karls Land a key reference area for the Late Triassic to Early Cretaceous development of the northern Barents Sea shelf.

The lithostratigraphy subdivision used herein (Fig. 3) follows the formal subdivision published by Mørk et al. (1999) with only a minor revision. A detailed biostratigraphy of the studied sections is provided by Smelror et al. (2018). The main purpose of the present paper is to present our interpretation of the depositional environments, key sequence stratigraphic surfaces and tectonic development of the Kong Karls Land succession. Also some few nearby offshore seismic lines are included in the study. The succession has been subdivided into six tectonic megasequences; TMS 1-6.

Within this context we also compare the succession and the depositional environments with those in other areas in the Svalbard archipelago and the Barents Sea.

\section{History and previous work}

The importance of Kong Karls Land as a key area connecting the exposures of Svalbard and the offshore Barents Sea shelf became progressively clearer during the 1970s and 1980s. Worsley \& Heintz (1977) emphasised the similarities between the Kong Karls Land succession and the other eastern islands of Svalbard, a view further advocated by Edwards et al. (1979). However, local stratigraphic schemes were established by the Cambridge research group (Cambridge Arctic Shelf Programme; CASP) (Hopen: Smith et al., 1975, Kong Karls Land: Smith et al., 1976; Barentsøya and Edgeøya: Lock et al., 1978), with the suggestion that these schemes should be used until the region could be treated as a whole (Pickton et al., 1979; Harland, 1997). Meanwhile, several palaeontological contributions also indicated clear similarities between Kong Karls Land and the other Svalbard islands (Bjærke, 1977; Løfaldli, 1978; Verdenius, 1978; Løfaldli \& Nagy, 1980; Rawson, 1982; Smelror, 1988; Doyle \& Kelly, 1988; Smelror et al., 1998). A sequencestratigraphic comparison linking the Kong Karls Land succession with the rest of the Barents Sea was presented by Johannessen \& Embry (1989). Lithostratigraphic compilation and standardisation was carried out by Mørk et al. (1999).

\section{Geological setting}

As in Svalbard, the platform areas to the south and east show the Mesozoic succession resting on a Late Palaeozoic rift system (Worsley, 2008). While the southwestern Barents Sea experienced a second extensional phase of the North Atlantic rift system in the Late Jurassic-Early Cretaceous (Faleide et al., 2008), the Late Palaeozoic rift system in the northern Barents Sea is overlain by relatively flat-lying or gently folded sequences of Late Permian and Mesozoic age (Grogan et al., 1999).

The Kong Karls Land archipelago is a group of islands situated on the Kong Karls Land Platform (Fig. 1). Sediments of latest Triassic, Jurassic and Early Cretaceous age (Smith et al., 1976; Smelror et al., 2018) and dolerites of probable Barremian/Aptian age (Corfu et al., 2013) are exposed on the islands. Quaternary deposits, i.e., mostly raised beaches (Ingolfson et al., 1995), cover Mesozoic strata in the lower levels of the islands.

Throughout the Triassic, the northeastern Barents Sea shelf including the Kong Karls Land Platform was gradually infilled by a large-scale deltaic progradation sourced largely from the Ural Mountains, Novaya Zemlya and continental areas to the southeast (Petrov et al., 2008). By Carnian-Early Norian times the deltaic progradation had reached Kong Karls Land (Riis et al., 2008; Glørstad- 


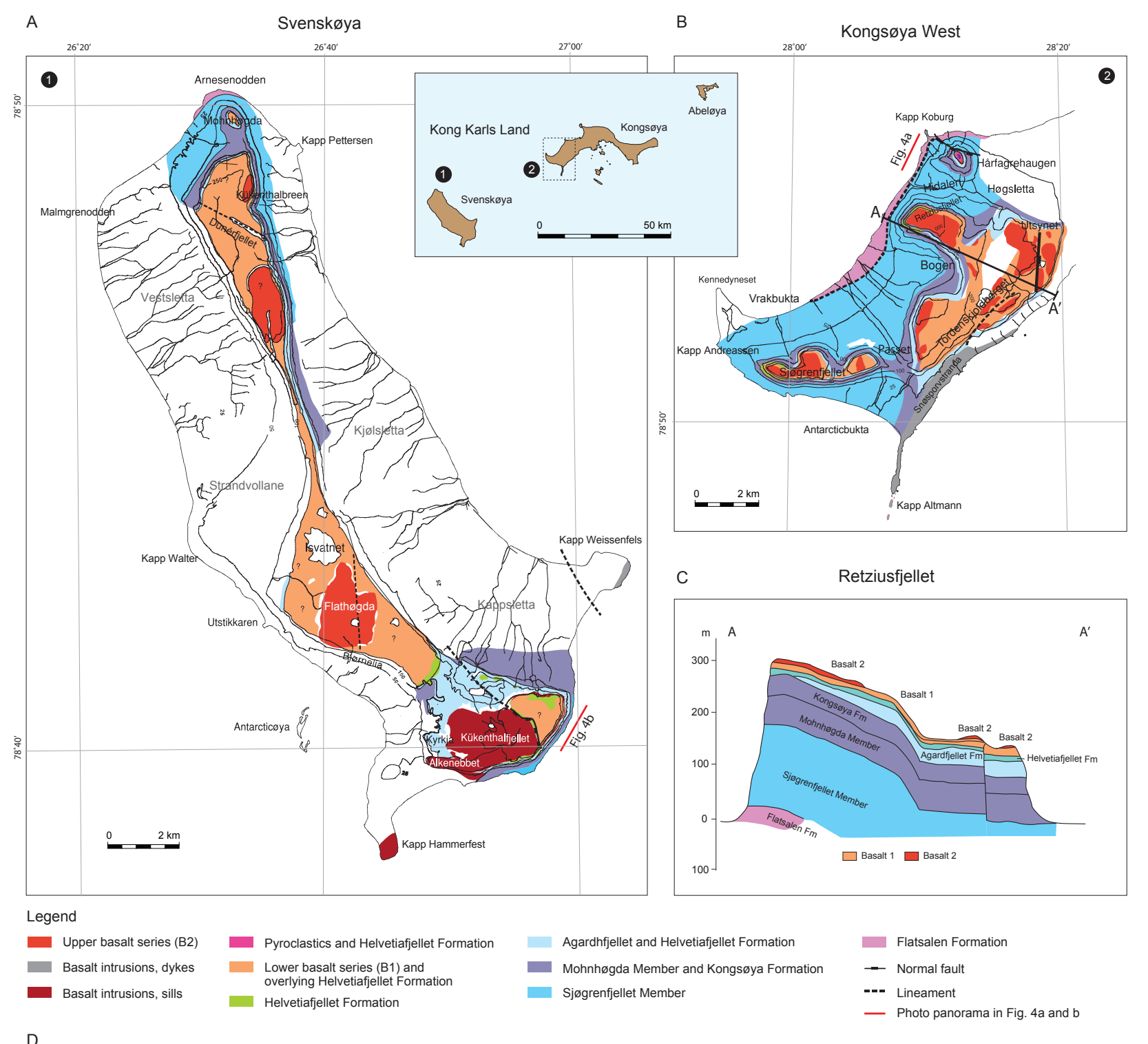

D

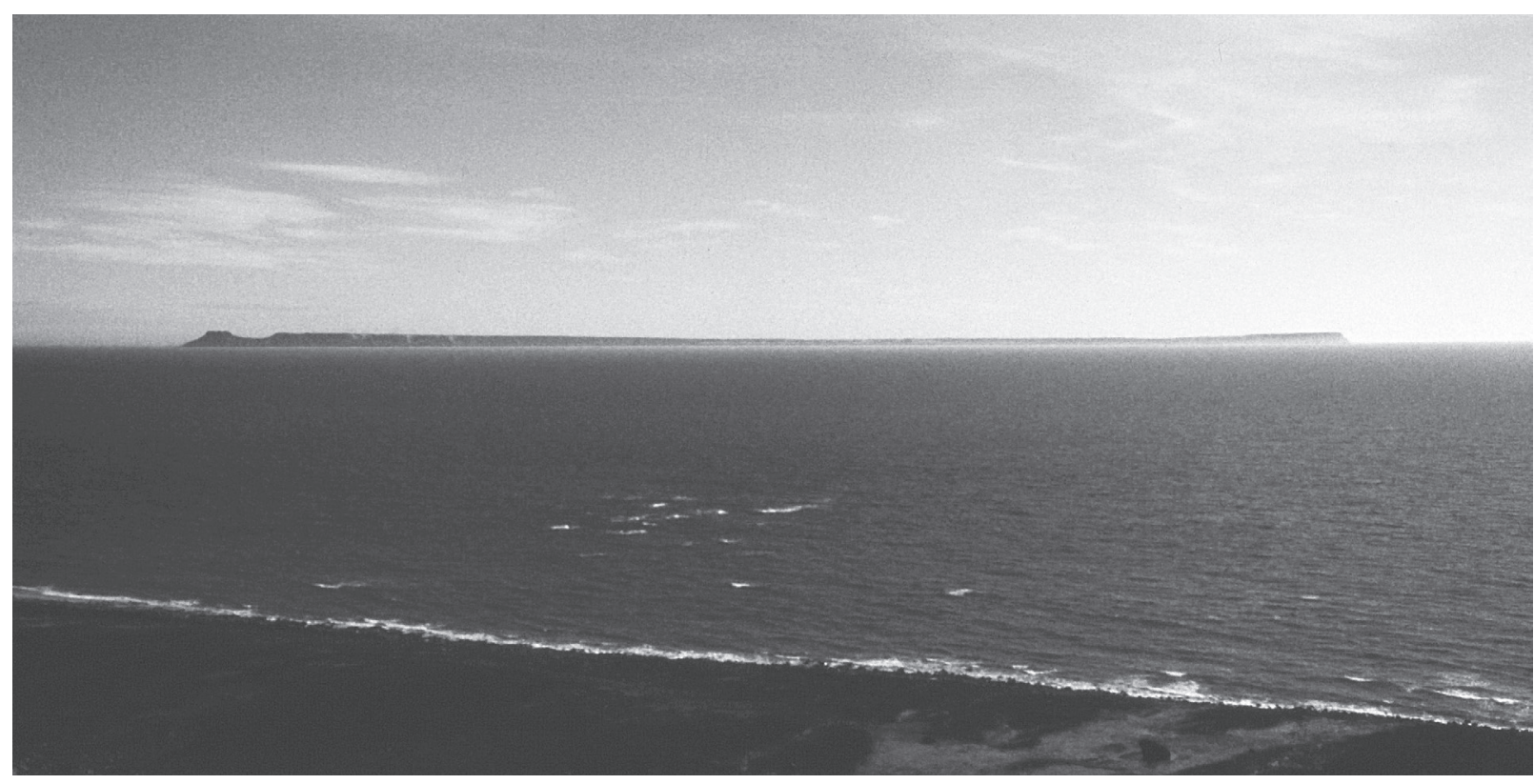

Figure 2. Geological maps. (A) Svenskøya. (B) Western Kongsøya. (C) Simplified profile A-A' across western Kongsøya through Retziusfjellet constructed from the geological map, structural upward thinning of the Agardhfjellet Formation. (D) Shows the gentle syncline of Svenskøya. The photo is taken from the west coast of Kongsøya facing the northeast coast of Svenskøya. 


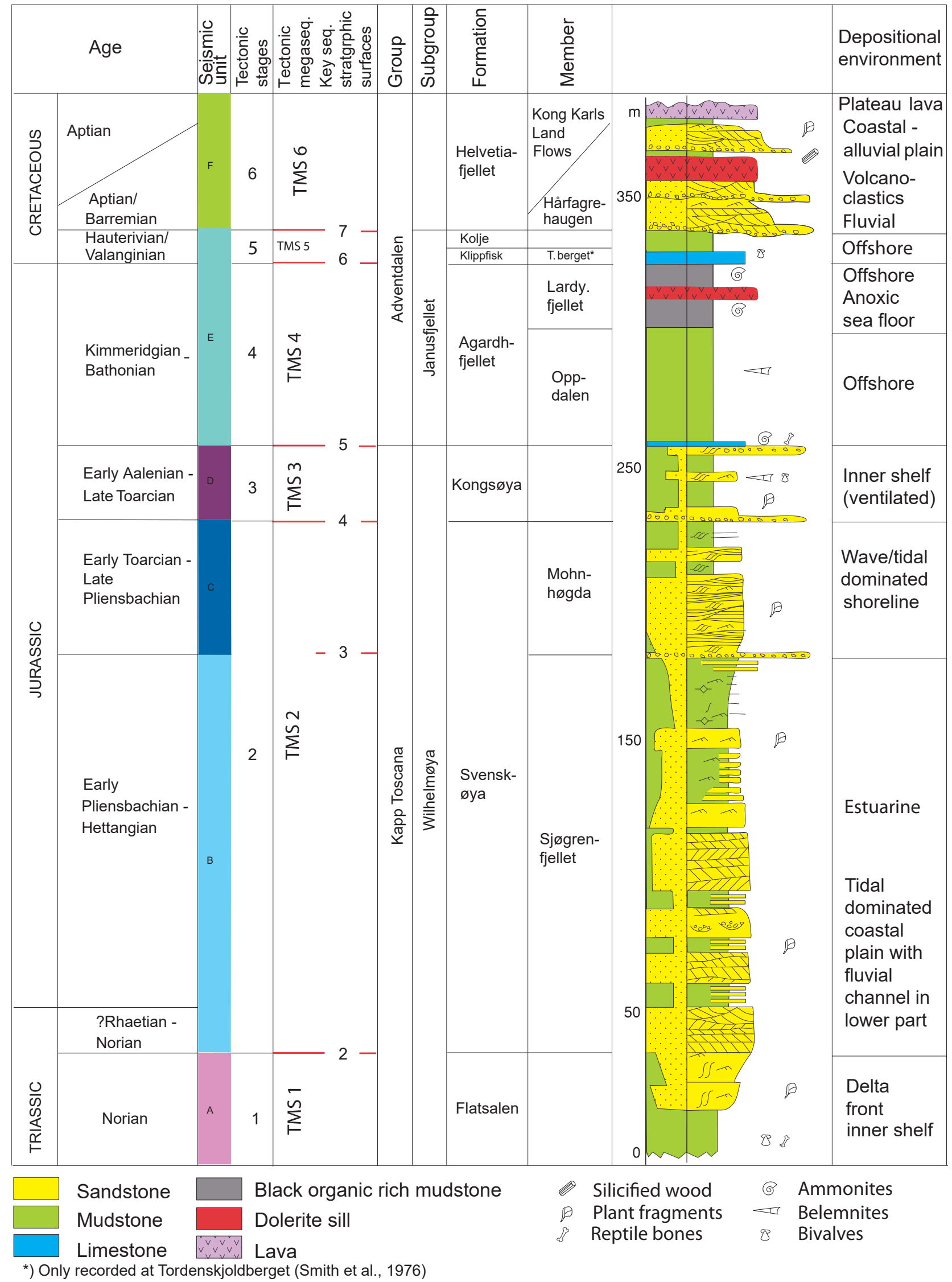

Figure 3. Simplified stratigraphic columns of the Mesozoic strata in Kong Karls Land. The informal subdivisions of Tectonic Megasequences (TMS), tectonic stages, seismic units and key sequence-stratigraphic boundaries. Red lines mark the defined sequence boundaries which are discussed below in this paper. The Dolerite sills are assigned to the Diabasodden Suite. 
Clark et al., 2010, 2011; Anell et al., 2014a, b). The Upper Triassic and Lower Jurassic succession on the Kong Karls Land Platform is significantly thicker than in the rest of Svalbard (Riis et al., 2008).

The latest Carnian to Norian deposits on Svalbard mark the transition from the mainly northwestward prograding Triassic shorelines to the aggrading sandstone units of the latest Triassic to Middle Jurassic (Anell et al., 2014a, b; Ryseth, 2014). This transition represents changes in the tectonic regime of Svalbard and the Barents Sea (Worsley, 2008).

Norian to Middle Jurassic, shallow-marine, tidal and coastal sediments were deposited in a slowly subsiding epicontinental basin which covered most of the western Barents Sea and Svalbard (Worsley, 2008). Thus, small changes in relative sea level during the Norian to Middle Jurassic resulted in subaerial unconformities, regional condensed successions and lacunas. Apparently, the preTriassic structural highs, such as southern Spitsbergen, the Stappen High and the Gardarbanken High, became areas with very slow deposition and condensed deposits, while more continuous sections were developed in the pre-Triassic structural lows (Glørstad-Clark et al., 2010; Anell et al., 2014c).

In Kong Karls Land and on the Kong Karls Land Platform, there is a 200 m-thick, almost complete Upper Norian to Late Pliensbachian succession, in contrast to the 5 to $20 \mathrm{~m}$-thick condensed or eroded units with several hiatuses in western Spitsbergen (Bäckström \& Nagy, 1985; Krajewski, 1990; Nagy \& Berge, 2008; Rismyhr et al., 2019). This reflects a higher rate of accommodation space being generated in Kong Karls Land relative to Spitsbergen. A similar trend is also seen on the Barents Sea Shelf (Henriksen et al., 2011). During this time, western Spitsbergen must have periodically acted as a structural high, probably slightly tilted towards the east. By Late Pliensbachian to Toarcian/Aalenian times, these differences levelled out and the basin fill is represented by thin condensed units all over Svalbard (Bäckstrøm \& Nagy, 1985), indicating an extensive and stable structural high with periodic subaerial exposure.

Kong Karls Land and the platform belong to the central and eastern sectors of the northern Norwegian Barents Sea, where the structural pattern is dominated by NESW-trending, regional, gentle folds with amplitudes of 100 to $300 \mathrm{~m}$ and wavelengths of several kilometres (Grogan et al., 1999). Reverse faults may occur in the central parts of these folds (Sigmond, 1992). One such fold is located in the western part of Kongsøya (Grogan et al., 1999). Field relations and evidence from seismic mapping in the area suggest that flexuring was initiated in the Late Jurassic and Early Cretaceous. The present-day structural configuration is the result of later reactivation of these folds.
As part of the breakup of the Laurasian supercontinent, the initial opening of the Amerasian Basin and formation of the Alpha Ridge in the Early Cretaceous resulted in crustal up-doming and extensive magmatic activity (Lane, 1997). These events are manifested by tholeiitic flood basalts in Kong Karls Land and adjacent areas (Baily \& Rasmussen, 1997), where they are observed on the summit plateaus of the main islands, and as sills and dykes emplaced in Permo-Carboniferous, Triassic, Jurassic and Cretaceous strata of Svalbard and the northern Barents Sea. This Cretaceous magmatic activity constitutes part of HALIP (High Arctic Large Igneous Province: Maher, 2001; Buchan \& Ernst, 2006; Minakov et al., 2012; Corfu et al., 2013; Petrov et al., 2016), extending from the Canadian Arctic Archipelago to Franz Josef Land and Kong Karls Land. Based on a compilation of radiometric age determinations, Polteau et al. (2015) suggest a Late Barremian age for the magmatism in Svalbard and the northern Barents Sea. The volcanic event on Kong Karls Land represents part of the HALIP (Maher, 2001). Polteau et al. (2010) have split the HALIP into two separate provinces: 1, the Barents Large Igneous Province (BLIP) with peak magmatism at $~ 120-130 \mathrm{My}$, and 2, the Sverdrup Large Igneous Province (SLIP) with peak magmatism at $\sim 80-90 \mathrm{My}$ ). The BLIP extends north of Kong Karls Land and southwards with a total area of approximately $700000 \mathrm{~km}^{2}$, giving a total magma volume of $75000 \mathrm{~km}^{3}$ (Polteau et al., 2010). This produced a shortlived heat flux in the area. No well-defined radiometric age data have been reported from the Kong Karls Land volcanic rocks, but recent $\mathrm{U}-\mathrm{Pb}$ ages on associated tuffs and intrusive rocks on Spitsbergen and Franz Josef Land indicate an Early Aptian age (Corfu et al., 2013).

Outcrops, cores and seismic data suggest that the entire northernmost Barents Sea was uplifted and eroded at this time, resulting in the progradation of sand-rich deposits towards the S-SE (Steel \& Worsley, 1984; Gjelberg \& Steel, 1995; Worsley, 2008; Midtkandal \& Nystuen, 2009). Several south and southeastward-directed Kimmeridgian to Albian clastic wedges occur in Svalbard (Grundvåg \& Olaussen, 2017; Grundvåg et al., 2017; Koevoets et al., 2018). On Franz Josef Land, Kong Karls Land, parts of Spitsbergen and along the basin margins in the Sverdrup Basin, Late Hauterivian/Early Barremian fluvial deposits with erosive bases overlie Upper Jurassic or Lower Cretaceous marine shales (Steel \& Worsley, 1984; Embry, 1991). In more distal areas the contact is conformable and in the southern Barents Sea no coarse clastics have been encountered except for clastic wedges fringing internal basin highs and locally derived faultscarp deposits (Seldal, 2005; Marin et al., 2017a). Upper Barremian and Aptian sandstones throughout Svalbard contain plagioclase grains and volcanic lithics associated with the HALIP source together with basement grains (Maher et al., 2004).

In general, the degree of consolidation of Mesozoic sediments decreases eastwards from the West Spitsbergen 
Fold-and-Thrust belt, as a result of less burial and overburden in east. The overburden in Kong Karls Land and in the northern Barents Sea was removed through cycles of Cenozoic tectonism, uplift and subsequent erosion followed by glacial erosion in the Quaternary (Faleide et al., 1993, 1996).

\section{Geological map}

Fieldwork was undertaken in the northern and southern part of Svenskøya (Fig. 2A) and in the western part of Kongsøya (Fig. 2B). Profiles and structural geological observations were plotted on air photos and transferred to the topographical maps. As part of this fieldwork, more detailed geological maps than the pre-existing 1:500,000 map of Lauritzen \& Ohta (1984) were produced for Svenskøya and the western part of Kongsøya (Fig. 2).

The map of Kongsøya reveals a NNE-SSW oriented anticline (Fig. 2C). Field observations combined with seismic data show that the high is an asymmetric gentle anticline where the eastern limb is expressed in the topography (Fig. 2C) while the more steeply dipping western limb is eroded and poorly exposed.

The axis of this anticline coincides with the tops of the highest mountains Sjøgrenfjellet, Retziusfjellet and Hårfagrehaugen, where the strata are approximately horizontal. The topographical slope eastwards from the axis expresses the inclination of the strata. This is easily seen on the crest east of Retziusfjellet, where the structural dip down to the southeast is marked by units which are resistant to erosion. The maximum dip of the eastern flank on Kongsøya is about $15^{\circ}$. Further towards the east, the flank flattens to form the plateau at Utsynet. The western flank of the anticline is poorly exposed, and beds dipping to the northwest are only observed locally on the western coast of Kongsøya. On Svenskøya, the basalt cover forms a very gentle synclinal structure, with its lowermost point in the north on Flathøgda (Fig. 2D). Due to the gentle structure it is difficult to ascertain the orientation of the fold axis there. The anticline was interpreted in seismic lines south and north of Kongsøya and becomes more deeply eroded to the north, and shows that at the Permian-Lower Triassic level it is between 5 and $10 \mathrm{~km}$ wide with an elevation difference of approximately 200 metres between the synclinal depression and the anticlinal crest, which is regarded to be consistent with the field observations. Reverse-fault offsets with a magnitude of 10-20 metres can be observed along the axial plane of the anticline structure, while a normal fault, possibly caused by buckling, is interpreted in the crest. The nature of the structure at levels deeper than the Permian is difficult to interpret in these data. The dimensions and orientation of the structure are comparable with the structures observed in seismic data on the surrounding shelf (Fig. 1).
The geological maps of Lauritzen \& Ohta (1984) show that Jurassic sediments are only exposed in a few localities in the central part of Kongsøya. The extensive basaltic plateau there represents intrusive rocks into the Jurassic level. This suggests that the central part of Kongsøya, east of the investigated area, is located in a structurally low area.

\section{Stratigraphic subdivision}

With a few exceptions the lithostratigraphic nomenclature follows Mørk et al. (1999). This is shown together with the sequence-stratigraphic subdivision in Fig. 3.

Based on stratigraphic similarities between Kong Karls Land and Spitsbergen we have informally used the nomenclature from Spitsbergen for the two lower members in the Agardhfjellet Formation where Oppdalen Member replaces Bünsowbukta Member and Lardyfjellet Member replaces Høgsletta Member (cf., Mørk et al., 1999). We also use the formal Barents Sea formation and member names when referring to comparable offshore strata. Panorama photos from Svenskøya and Kongsøya show an overview of the outcropping succession and the lithostratigraphic units in Kong Karls Land (Fig. 4).

\section{Kong Karls Land Upper Triassic to Lower Cretaceous outcrops and their seismic correlation to the northern Barents Sea}

During the 1990s, the Norwegian Petroleum Directorate (NPD) carried out regional mapping of the northern Barents Sea (Grogan et al., 1999; Riis et al., 2008). This activity comprised the acquisition and interpretation of reflection seismic data and of shallow stratigraphic boreholes on the continental shelf, combined with the collection and analysis of geological data from field expeditions on Svalbard. In areas south and east of Kong Karls Land, NPD acquired a regional seismic grid with a density of $8 \times 8 \mathrm{~km}$. To the north and west only scattered lines exist. The data are of varying age and quality.

Three seismic lines close to the islands (3000-90, 784590 and SB-3-90) provide the main basis for correlation to outcrops (Figs. 5B , 6 \& 7). Seismic line SB04-89 (Fig. $5 \mathrm{~A}$ ) illustrates the development of the upper part of the section farther away from the islands, where it is not disturbed by magmatic intrusions.

With the existing data it was not possible to directly correlate the shallow seismic lines to the exploration wells penetrating Mesozoic rocks in the Barents Sea. 
Hårfagrehaugen
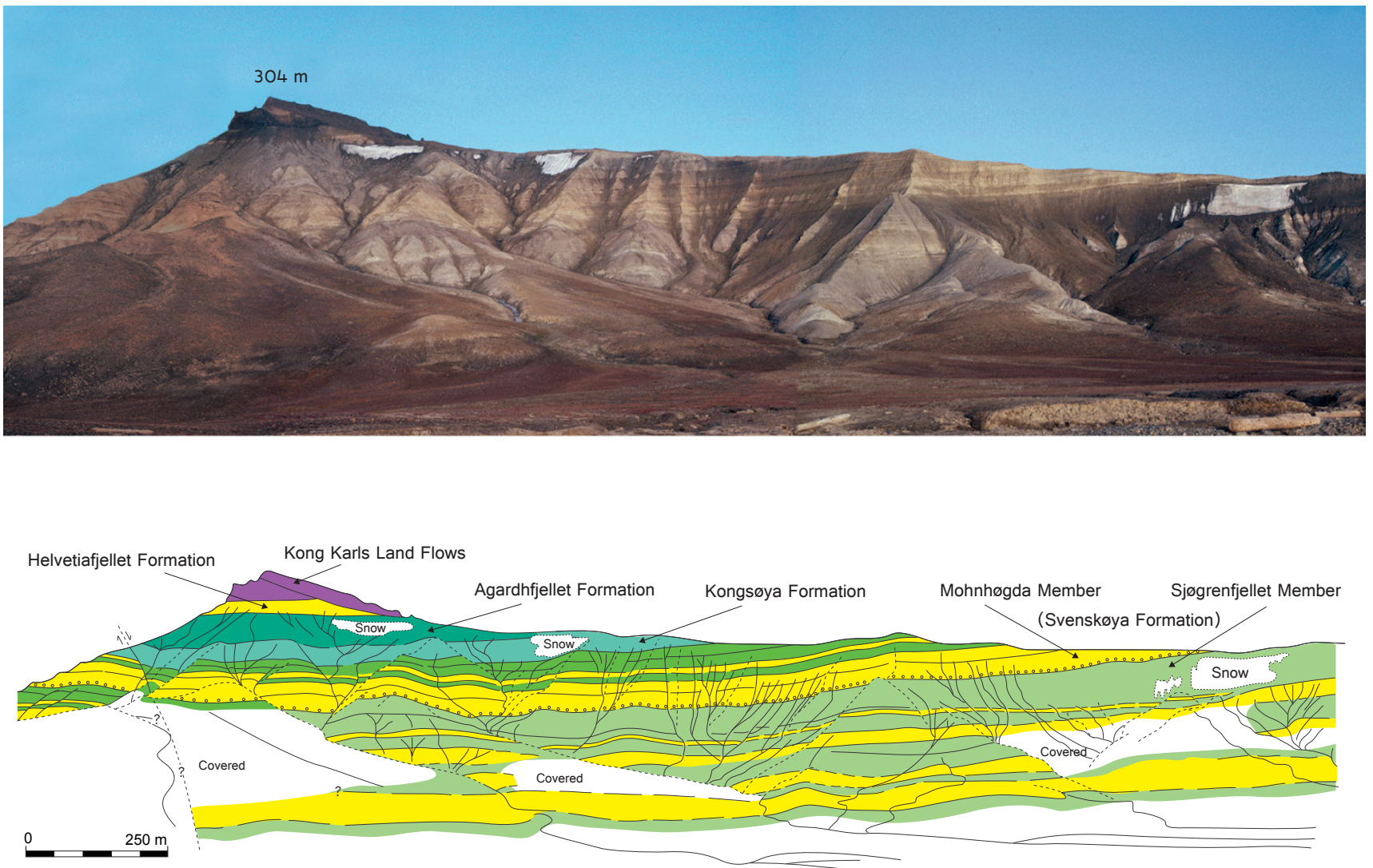

Kükenthalfjellet S Section
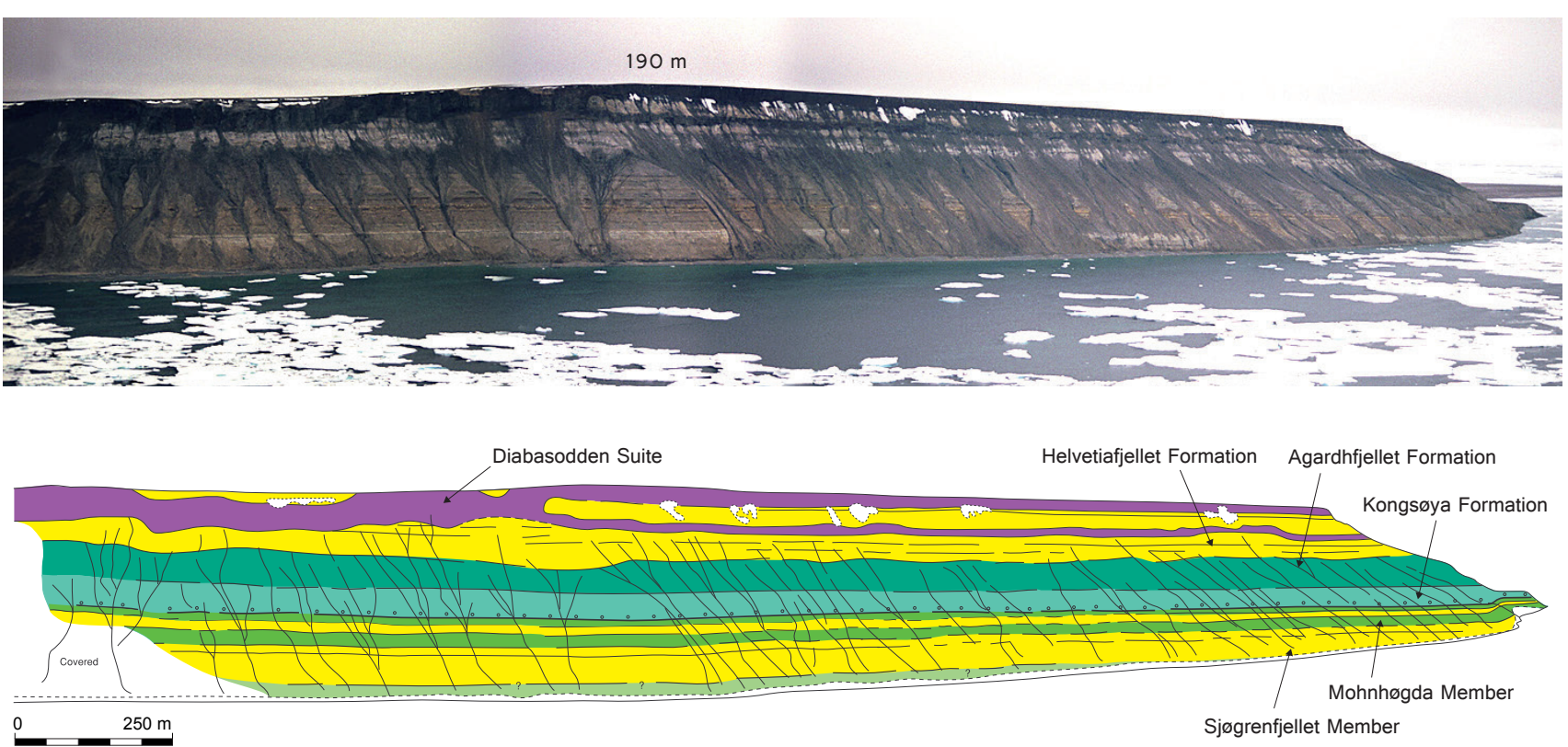

Figure 4. Panorama photos and stratigraphy of cliff sections from Kongsøya and Svenskøya.(A) Coastal cliff at Hårfagrehaugen, Kongsøya, facing towards Northwest. (B) Coastal cliff at Kükenthalfjellet, Svenskøya, facing towards Southeast. See Fig. 2 for locations. 

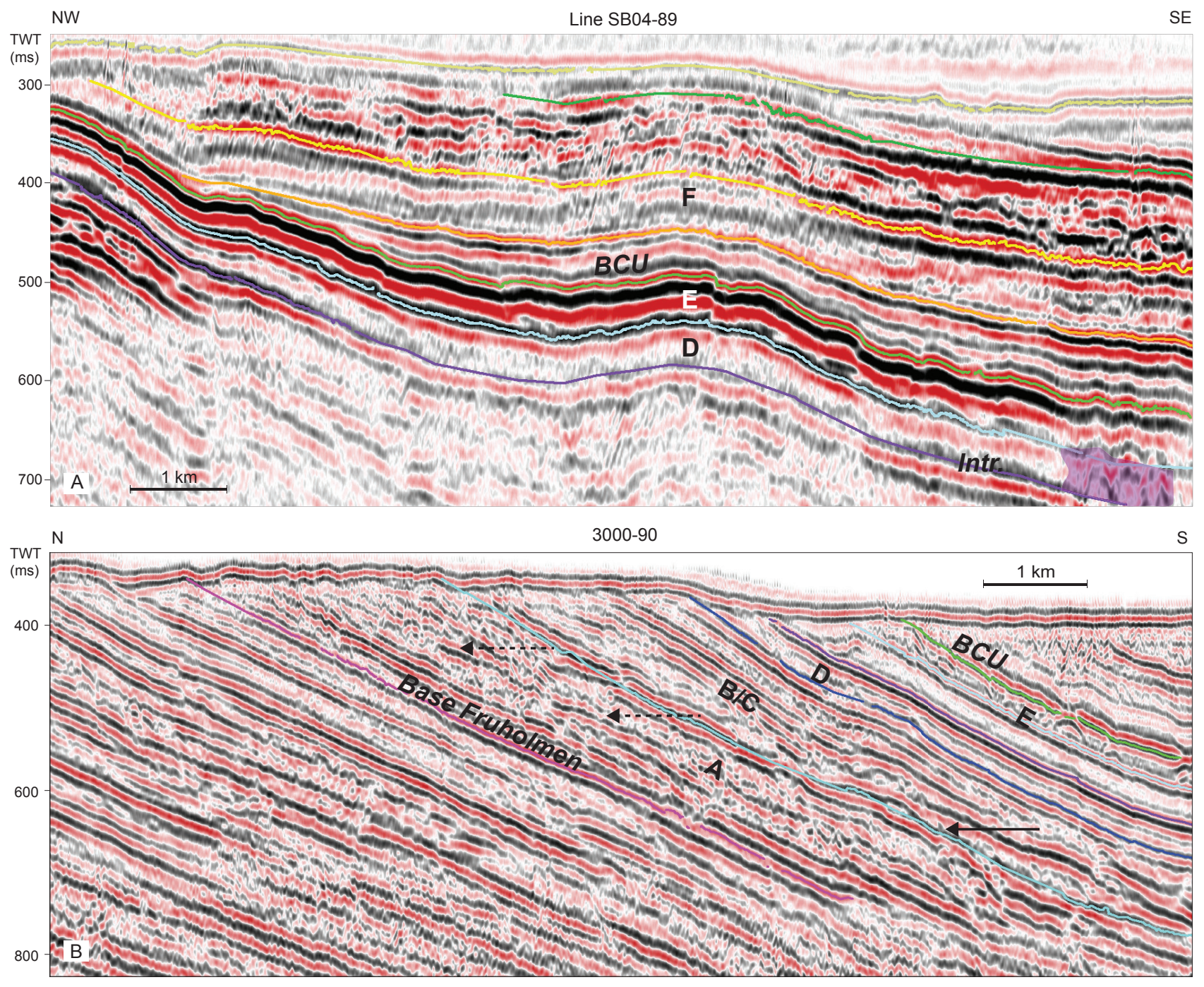

Figure 5. Shallow seismic lines. (A) Line SB04-89. Seismic units D, E and F are from the flank of an anticline. Violet line - Base seismic unit $D$, light blue - Base Seismic unit E, green line - Base Seismic unit F (Base Cretaceous), orange line - Top of onlapping, apparently shaly unit (?Valanginian-Hauterivian), yellow line - Reflector separating two sandy units in the Helvetiafjellet Formation, upper green line - Interpreted top of Helvetiafjellet Formation, lower right - Intrusive rocks in the Upper Jurassic. (B) Line 3000-90: Seismic character of the sea-floor subcrop of seismic units A to F. Horizon colours as in Fig. 5A. BCU - Base Cretaceous Unconformity. Arrows suggest onlapping character of the reflector near the Norian Rhaetian Boundary surface and possibly internally within the Fruholmen Formation, see also Fig. 34. Locations of the lines are marked in Figs. 1 \& 31.

A reliable long-distance correlation was obtained for the Base Cretaceous reflector, which has been cored in shallow drillholes in the southern part of the Olga Basin (Fig. 1).

Six seismic units, A to F, were interpreted and correlated to the outcropping sequences based on the seismic character of the seismic reflectors and time thickness between unit boundaries (Figs. 6 \& 7). These are further discussed in the tectonic sequence-stratigraphy chapter.

\section{Facies and facies associations of the Mesozoic succession in Kong Karls Land}

In total, 16 sedimentary facies have been identified within the Mesozoic succession in Kong Karls Land. Their characteristics and occurrences are summarised in Table 1. They provide the background for the facies associations defined, discussed and linked to each lithostratigraphic unit.

The associations are termed FA, with a prefix of the unit and thereafter numbered: for example FAs in the Sjøgrenfjellet Member will be SFA-1, SFA-2 and so on. 


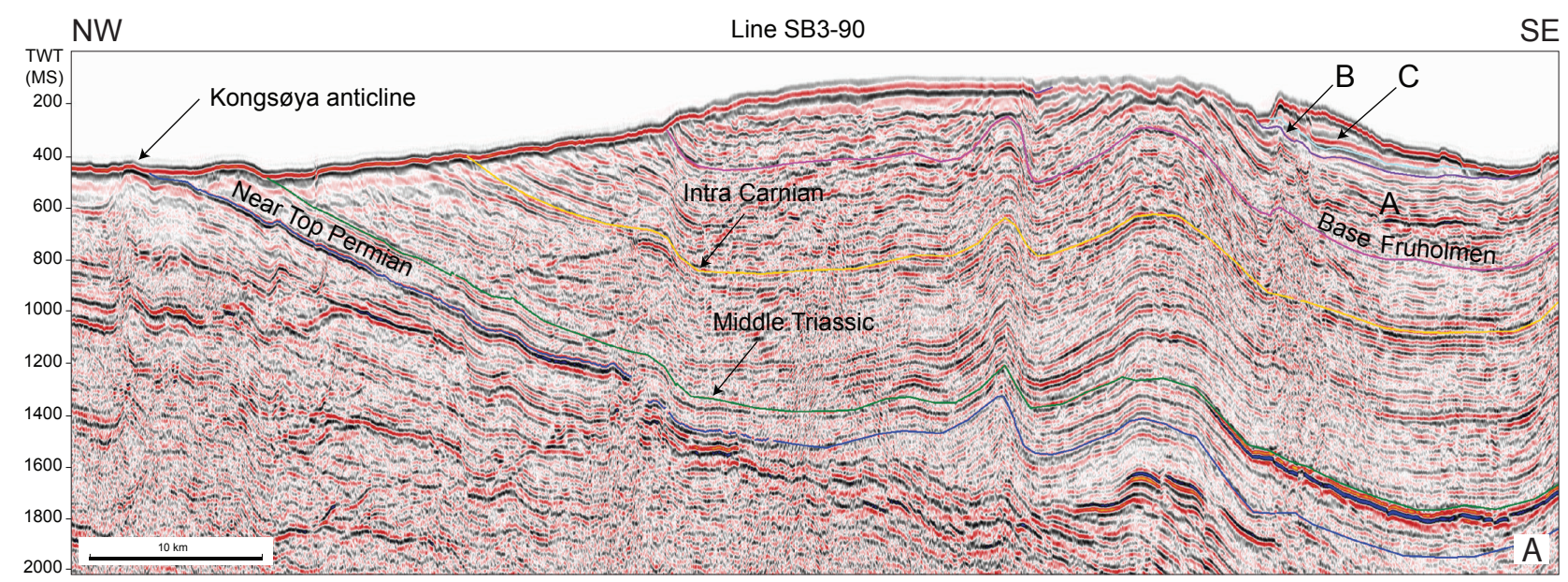

NNW

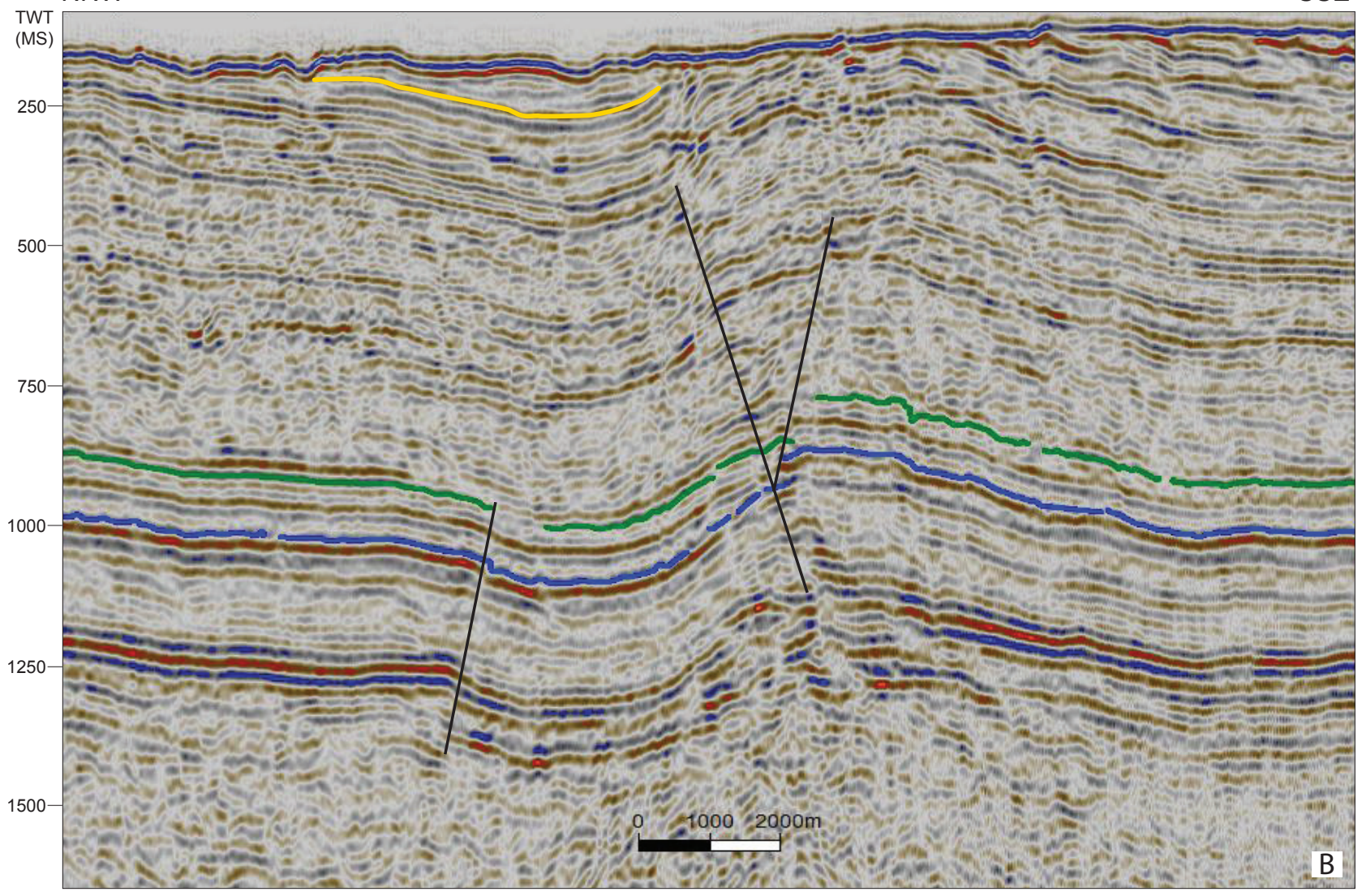

Figure 6. Interpreted seismic cross-section which shows the correlation between the stratigraphic succession from Kong Karls Land and the deeper units. (A) Line SB3-90. Interpreted Base Fruholmen Formation is used for constructing the approximate thickness of the Flatsalen Formation in Kong Karls Land. Blue line - Near top Permian, green - Middle Triassic, yellow - intra Carnian, pink - Base seismic unit A (Norian; Base Fruholmen Formation), purple - Base seismic unit C (Toarcian). Strong reflections in the Middle Triassic section, lower right, are interpreted as sills. Note dipping sea-floor multiples. The profile displays folds which are typical for this sector of the northern Barents Sea. A thick Carnian section progrades to the NW above thin and distal Lower-Middle Triassic sediments (Upper Jurassic sediments are mostly eroded in this profile). The Quaternary cover is typically only a few metres thick. Shaly lithologies are characterised by a smooth sea-floor surface, while the Norian to Middle Jurassic sandstone beds create a more rough topography. For location of line see Figs. 1 \& 31. (B) Seismic profile 2730-94C is aquired between Kongsøya and Svenskøya and shows a gentle anticline structure which is interpreted to be the continuation of the structure observed on Kongsøya. The seismic line shows that the entire Late Palaeozoic and Triassic section is folded. Svenskøya Formation and younger strata are eroded in this location. Blue reflector - Near top Permian, green - Near top Botneheia, yellow - intra Carnian. On Kongsøya, there are good exposures of the gently dipping southeastern limb of the fold structure. Vertical scale in milliseconds two way time. 


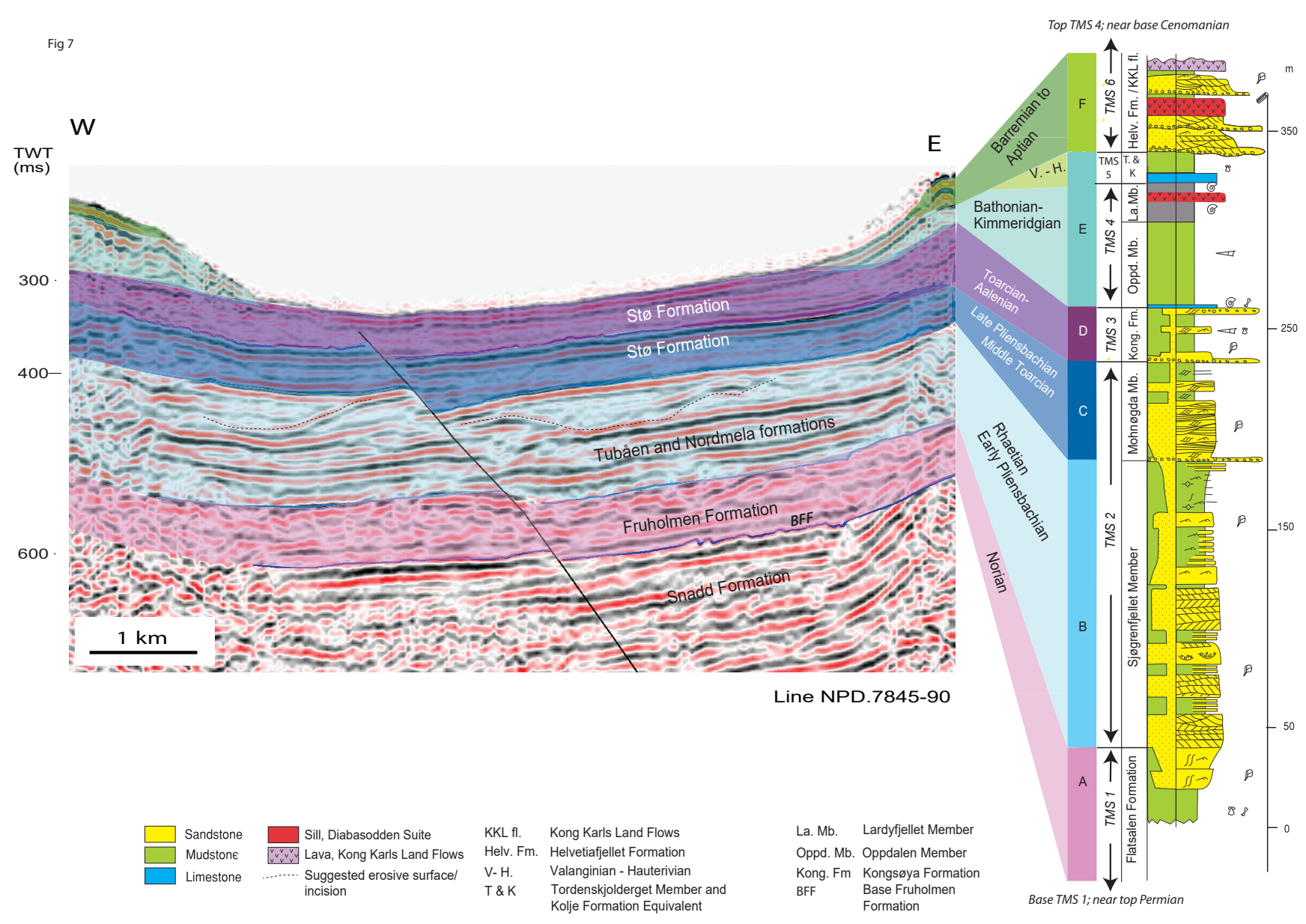

Figure 7. Onshore-offshore link of the strata exposed in Kong Karls Land. The shallow seismic line in 7845-90 shows that intrusions and lavas at the Upper Jurassic-Lower Cretaceous level occur on the sea floor to the left and right and mask the signals from the underlying section. However, the middle part of the line is the profile closest to the study area where all units underlying the Upper Jurassic can be interpreted. See also Figs. 5A, $B$ \& 6. BFF - Base Fruholmen Formation. Location of line: Fig. 1.

\section{The Norian Flatsalen Formation}

In Kong Karls Land the Flatsalen Formation displays a $37 \mathrm{~m}$-thick coarsening-upward succession of shale and sandstone. The upper and lower boundaries of the Flatsalen Formation are not exposed in Kong Karls Land. The Fruholmen Formation is the offshore equivalent of the Flatsalen Formation. Based on nearby seismic with a well-defined base Fruholmen reflector (Figs. 5, $6 \&$ 7), a near $100 \mathrm{~m}$ succession is suggested for the formation in Kong Karls Land. A comparable $53 \mathrm{~m}$-thick succession was studied in Hopen during the 1984 expedition. The boundary surfaces are well exposed on Hopen (Figs. 8 \& 9) (Mørk et al., 2013). We therefore include the Flatsalen Formation from Hopen in the present study.

On both Kong Karls Land and Hopen, three facies associations are recognised, covering all facies elements expected in repeatedly shallowing-upward trends from offshore or prodelta to shoreface or delta front depositional environments (Fig. 8).
Facies association FFA-1, transgressive shoreline

\section{Description}

The Slottet Bed at the base of the Flatsalen Formation is not exposed on Kong Karls Land, but is well exposed on Wilhelmøya to the west, Hopen to the south and on the eastern coast of Spitsbergen (Fig. 1) (Mørk et al., 1999). On Hopen, the $2 \mathrm{~m}$-thick glauconitic carbonate cemented pebbly sandstone (Facies 4, Table 1) of the Slottet Bed weathers white in its lower part, turning rusty red to orange upwards. It consists of scattered pebbles and gravel occurs in distinct beds or laminae. Bivalves are the dominating fossils, but a few vertebrate and wood fragments are also observed. A coquina bed consisting of broken bivalves occurs in its middle part. On Wilhelmøya, the Slottet Bed has a basal polymict conglomerate with phosphate pebbles and gravel, followed by pebbly carbonate cemented sandstone with glauconite (Mørk et al., 1999). Its middle part on Hopen contains two thin conglomerate beds that intersect the carbonate-cemented sandstone. Trace fossils found in this bed are Skolithos, Teichichnus and rare Rhizocorallium. 


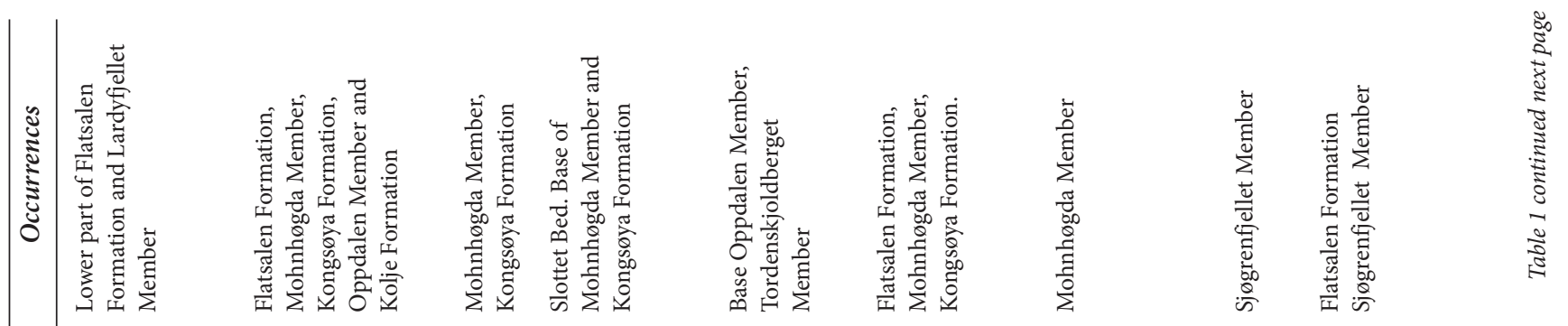
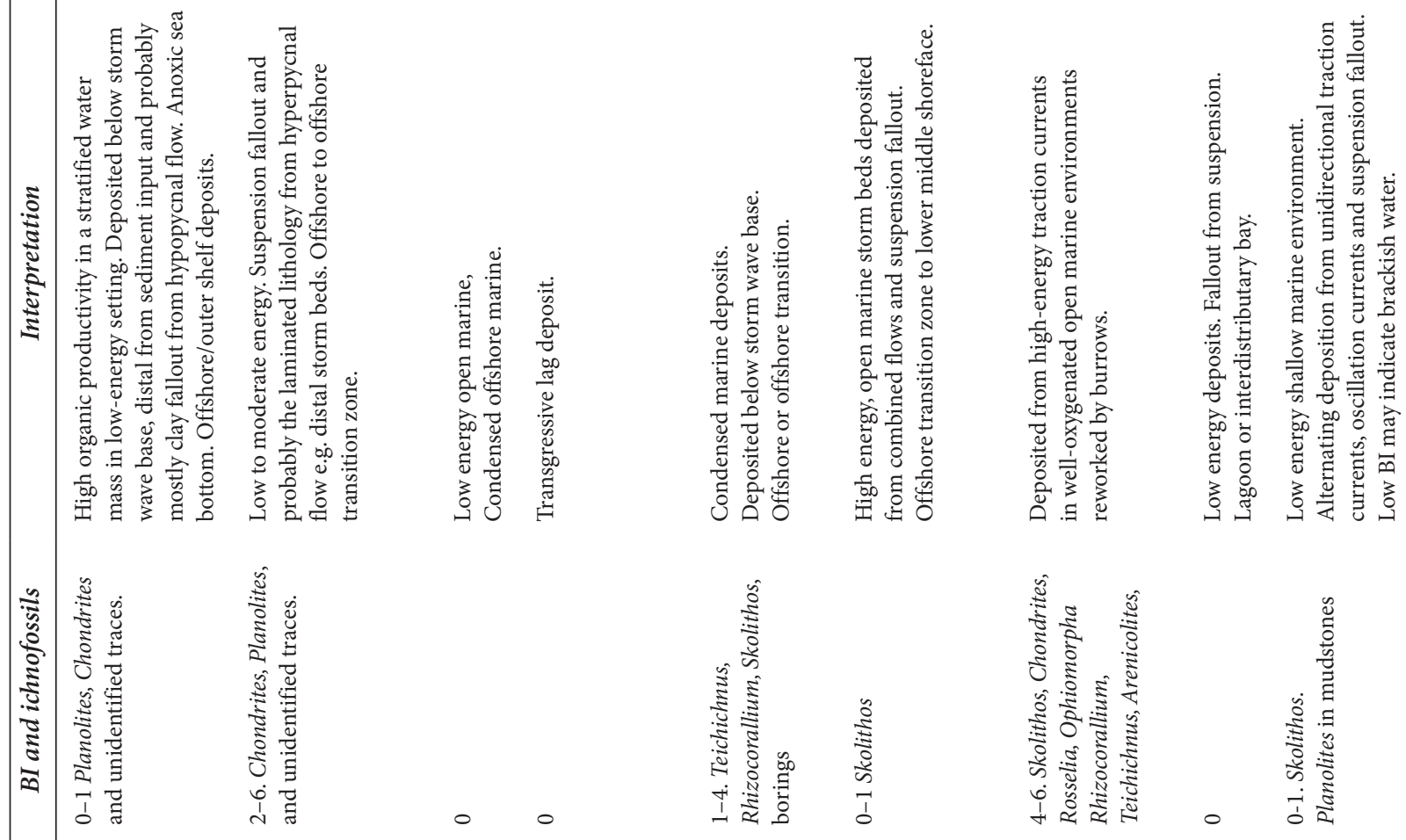

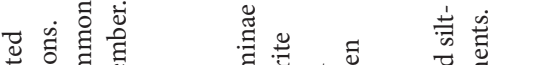

表

\section{.}

$\sqrt{1+2}$

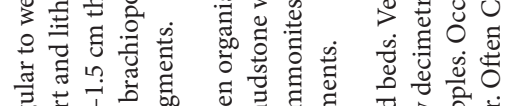

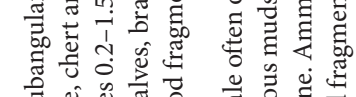

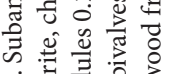

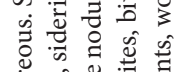

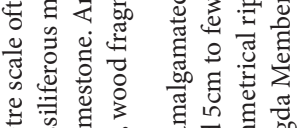

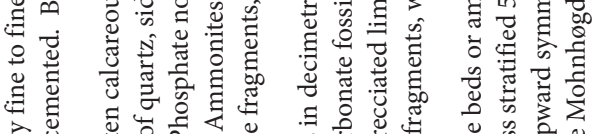

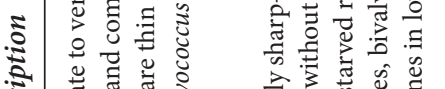




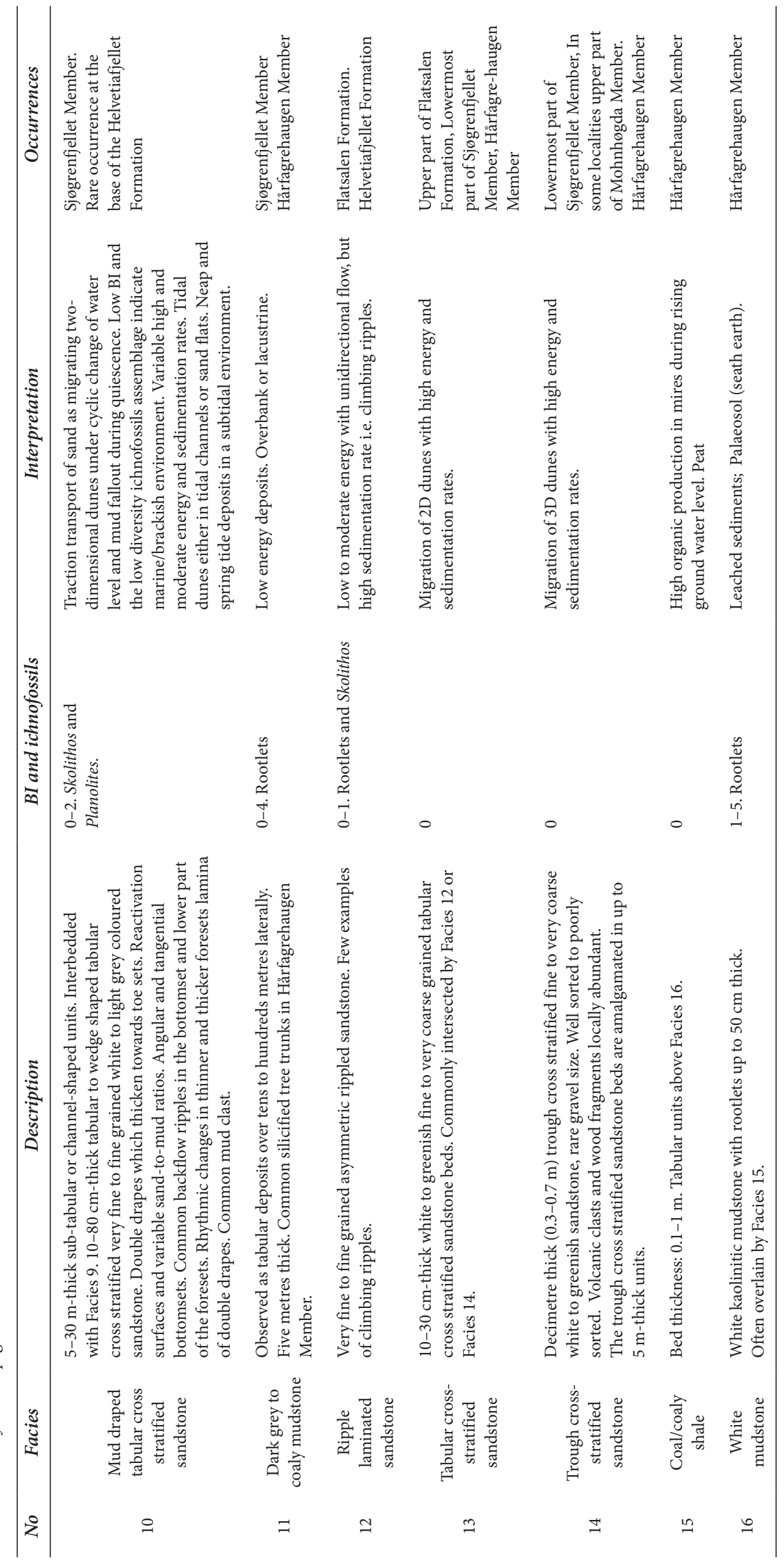




\section{Interpretation}

On Svalbard, the Slottet Bed has been interpreted as a transgressive lag deposit representing a major marine transgression in the Arctic (Johannessen \& Embry, 1989; Embry, 1997; Mørk \& Smelror, 2001). The basal conglomerate and erosive surface observed on Wilhelmøya and the occurrence of phosphate nodules, glauconite, marine fossils, and trace fossils belonging to Cruziana ichnofacies, suggest rapid transgression into shallow water. FFA 1 is interpreted as a transgressive lag, a deposit formed by strong erosion and winnowing by waves under open shallow-marine conditions during an overall transgression consistent with previous interpretations (Worsley, 1973; Mørk et al., 1999; Nagy \& Berge, 2008; Lord et al., 2014; Rismyhr et al., 2019).

Facies association FFA-2, outer shelf to lower shoreface CU units

\section{Description}

On Hopen, the Slottet Bed is overlain by a dark grey, organic-rich, pyritic clay-mudstone with thin siltstone laminae, siderite concretions and limited bioturbation (Facies 1 in Table 1) (Fig. 8). Above this mudstone, five well-defined, 5-13 m-thick, coarsening-upward (CU) units form a $50 \mathrm{~m}$-thick overall upward-coarsening package (Facies 2, 6 and 9, Table 1) (Figs. 8 \& 9). The $\mathrm{CU}$ units are capped by thin fining-upward (FU) units consisting of wave-rippled fine-grained sandstone to burrowed siltstones and mudstones, or by a sharp top surface. The four lower CU units comprise intensely bioturbated (e.g., by Chondrites) grey mudstones with shell fragments, carbonate-cemented beds with bivalve fragments, and siderite concretions at their base (Facies 2 in Table 1). These are replaced upwards by $3-30 \mathrm{~cm}$-thick interbedded siltstones and very fine-grained lenticular bedded sandstones with wave ripples, current ripples and a few hummocky cross-stratified beds (Facies 6, 9 in Table 1) (Fig. 8). Normal graded coquina beds (Facies 5, Table 1) are also observed. The marine phytoplankton Sverdrupiella, rare ammonites and marine reptile bones occur in the lower and middle part of the Flatsalen Formation (Mørk et al., 2013). Overall, there is a gradual increase in pollen, spores and the freshwater influenced algae Botryococcus upward in the Flatsalen Formation on Hopen (Paterson \& Mangerud, 2015; Smelror et al., 2018).

On Kong Karls Land, the lower exposed part of the Flatsalen Formation includes comparable facies and trace fossils to those observed on Hopen, but with less defined CU units and with common current ripples (Fig. 8). The lowermost exposure consists of laminated dark grey mudstones (Facies 1, Table 1) with pyrite nodules, bivalves, ammonites and marine palynomorphs (Smelror et al., 2018). Marine reptiles on Kongsøya were also reported in the lower finer-grained part by Worsley \& Heintz (1977), but these exposures have clearly been subject to marine erosion.

\section{Interpretation}

The vertical organisation of the lower four CU units on Hopen with increasing influence of freshwater algae upwards, are interpreted in terms of repeated shallowingupwards units of prograding shorelines. Lenticular bedding with current ripples, wave ripples and scattered hummocky cross-stratification (Facies 6, 9 in Table 1) suggest deposition from oscillatory and unidirectional flow (Dumas \& Arnott, 2006), probably between fairweather and storm-wave base in an offshore to transition zone or prodelta to lower shoreface depositional environment. The sharp upper boundaries of some of the CU units suggest abrupt flooding or transgression, probably as a result of an autocyclic coastline or delta lobe shift leading to a sudden rise in base level. Where $\mathrm{CU}$ units are overlain by FU units, this is suggested to reflect a more gradual rise in base level. The presence of dark, organic-rich and laminated pyritic claystones with limited bioturbation in the basal CU unit implies anoxic to suboxic bottom water conditions. At Kapp Koburg in Kong Karls Land, the lower exposed CU units are interpreted to have formed by mud settling from hypopycnal plumes and sand/silt from traction currents from dispersed river-fed hyperpycnal flows (Parsons et al., 2001; Mulder et al., 2003).

\section{Facies association FFA-3, shoreface and delta front \\ Description}

The uppermost CU unit on Hopen is terminated by very fine to fine-grained amalgamated hummocky crossstratified sandstones (Facies 6 in Table 1) (Fig. 8). On Kong Karls Land, the uppermost $40 \mathrm{~m}$ of the Flatsalen Formation are exposed in the coastal cliffs at Kapp Koburg, Kongsøya. Here, it consists of two overall CU units with lower lenticular bedded parts with current or combined wave/current ripples (Facies 6 in Table 1, Fig. 10), passing up into coarser-grained sandstonedominated parts with decimetre-thick sets of tabular and trough cross-stratified sandstone (Figs. 8 \& 10A). Plant fragments, leaves and small wood fragments are common in the upper part.

\section{Interpretation}

The uppermost CU unit on Hopen, which continues the gradual upward-thickening and -coarsening trend of underlying CU units (from FFA-1 through FFA-3) (Fig. 8), suggests progradation and shallowing upwards in a nearshore depositional environment, i.e., a transition from offshore to lower/middle shoreface, cf., Clifton (2006). The gradual increase in freshwater algae upwards (Smelror et al., 2018) is also consistent with this overall regressive character. The dominance of wave and hummocky cross-stratification suggests a wavedominated coastline.

In contrast to Hopen, the two CU units in Kong Karls Land pass upwards into tabular and rare trough crossstratified sandstone beds interpreted as shallow-marine $2 \mathrm{D}$ and $3 \mathrm{D}$ dunes. They are interpreted as delta-front 

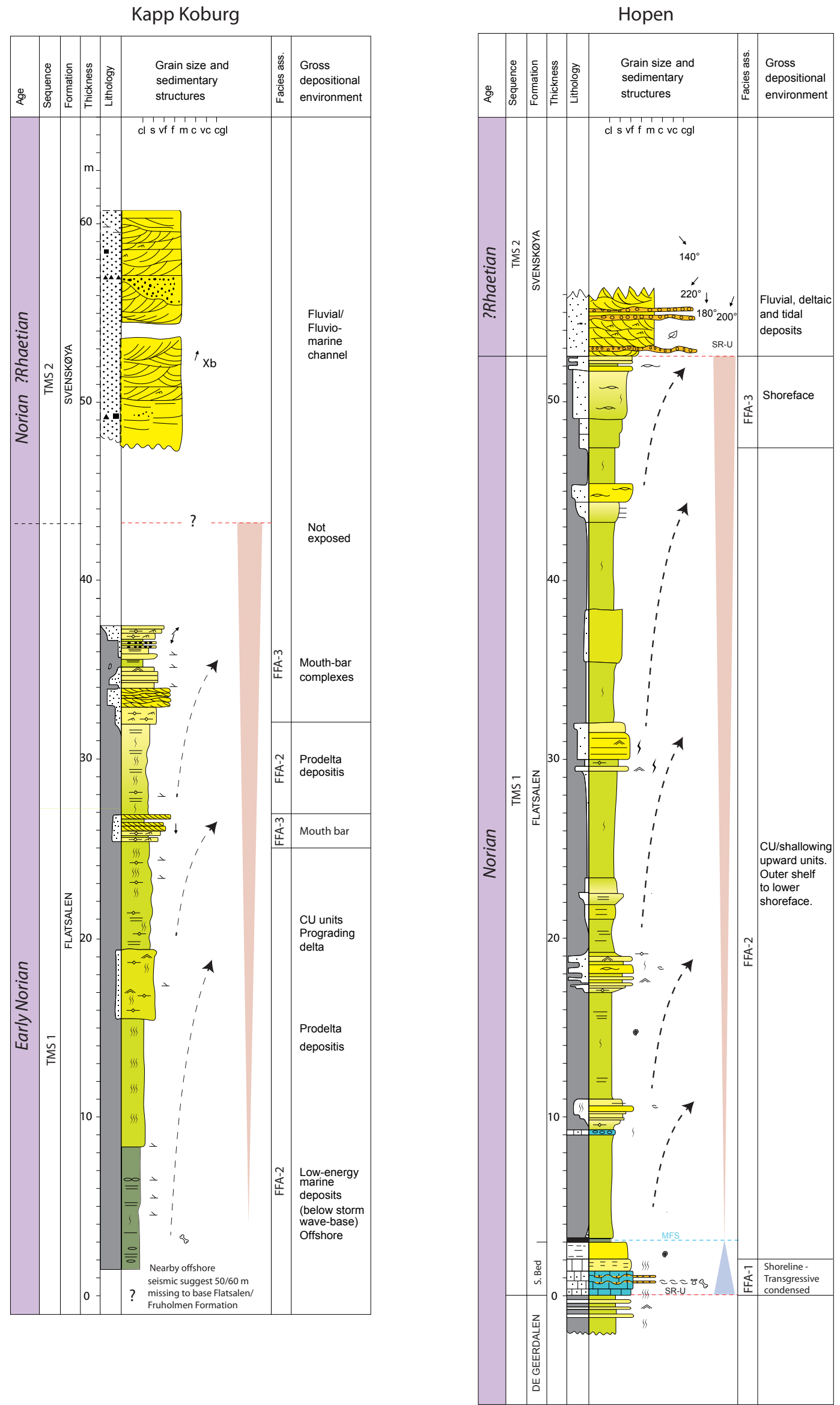

Figure 8. Stratigraphic columns of the Flatsalen Formation in northeastern Hopen and at Kapp Koburg, Kong Karls Land. While wave-dominated shallowing-upward units (shoreline progradation) are common on Hopen, current-dominated coarsening-upward units (stacked mouth bars?) are the main trend on Kapp Koburg. For legend see Fig. 22. 


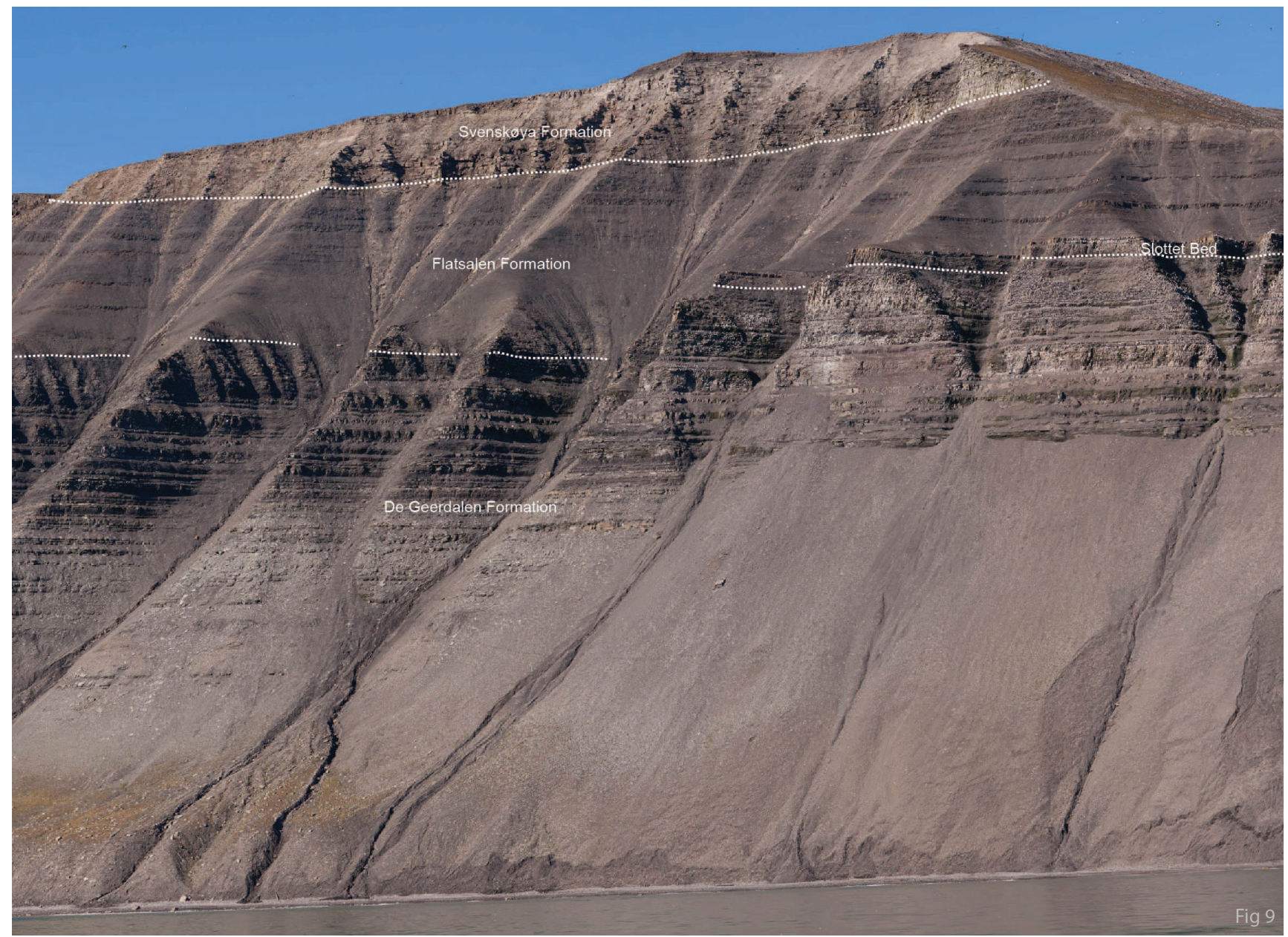

Figure 9. Flatsalen and Svenskøya formations in the NE part of Hopen. Lower stippled line marks the Early Norian pan-Arctic flooding event, while the upper stippled line marks the Rhaetian unconformity. Lyngefjellet, Hopen. See also Mørk et al., 2013, Lord et al., 2014. Photo: Terje Hellem.

or shoreline deposits (cf., Bhattacharya \& Walker, 1992). This interpretation is consistent with Smith et al. (1975) and Mørk et al. (2013), who also suggested deposition in a nearshore environment. In both places the gradual thickening of the $\mathrm{CU}$ units suggests prograding coastlines.

Summary of the depositional environment of the Flatsalen Formation

On both Hopen and Kong Karls Land the Flatsalen Formation consists of stacked CU units interpreted as offshore/prodelta to distal delta-front or lower shoreface deposits (FFA-2) capped by delta-front or shoreface deposits (FFA-3). This stacking pattern of facies associations is consistent with a stepwise progradation of the coastline.

\section{The Rhaetian-Middle Toarcian Svenskøya Formation}

The nearly 200 m-thick Svenskøya Formation consists of sandstone and shale with a variable net sandstone to shale ratio of $0.6-0.7$. The lower boundary is not exposed in Kong Karls Land, but the upper boundary is well defined by a conglomerate bed at the base of the Kongsøya Formation. The formation is subdivided in two members; a lower Sjøgrenfjellet Member and an upper Mohnhøgda Member. The boundary surface separating the two members can be correlated between Kongsøya and Svenskøya. The facies associations of the formation are discussed in the members below.

The Rhaetian-Lower Pliensbachian Siøgrenfjellet Member

The Sjøgrenfjellet Member is a nearly $150 \mathrm{~m}$-thick whitecoloured heterolithic unit consisting of moderately sorted, fine-to medium grained, white to weakly greenish quartz to subarkosic arenites (Fig. 11). Thin lenses and beds of mud pebble conglomerates are also seen in this member. The Sjøgrenfjellet Member contains deposits attributed to five different facies associations.

Facies association SFA-1, fluvial channel fill Description

On Kong Karls Land this association is only observed near the base of the Sjøgrenfjellet Member (Fig. 11). At Kapp Koburg it consists of an almost $12 \mathrm{~m}$-thick interval 

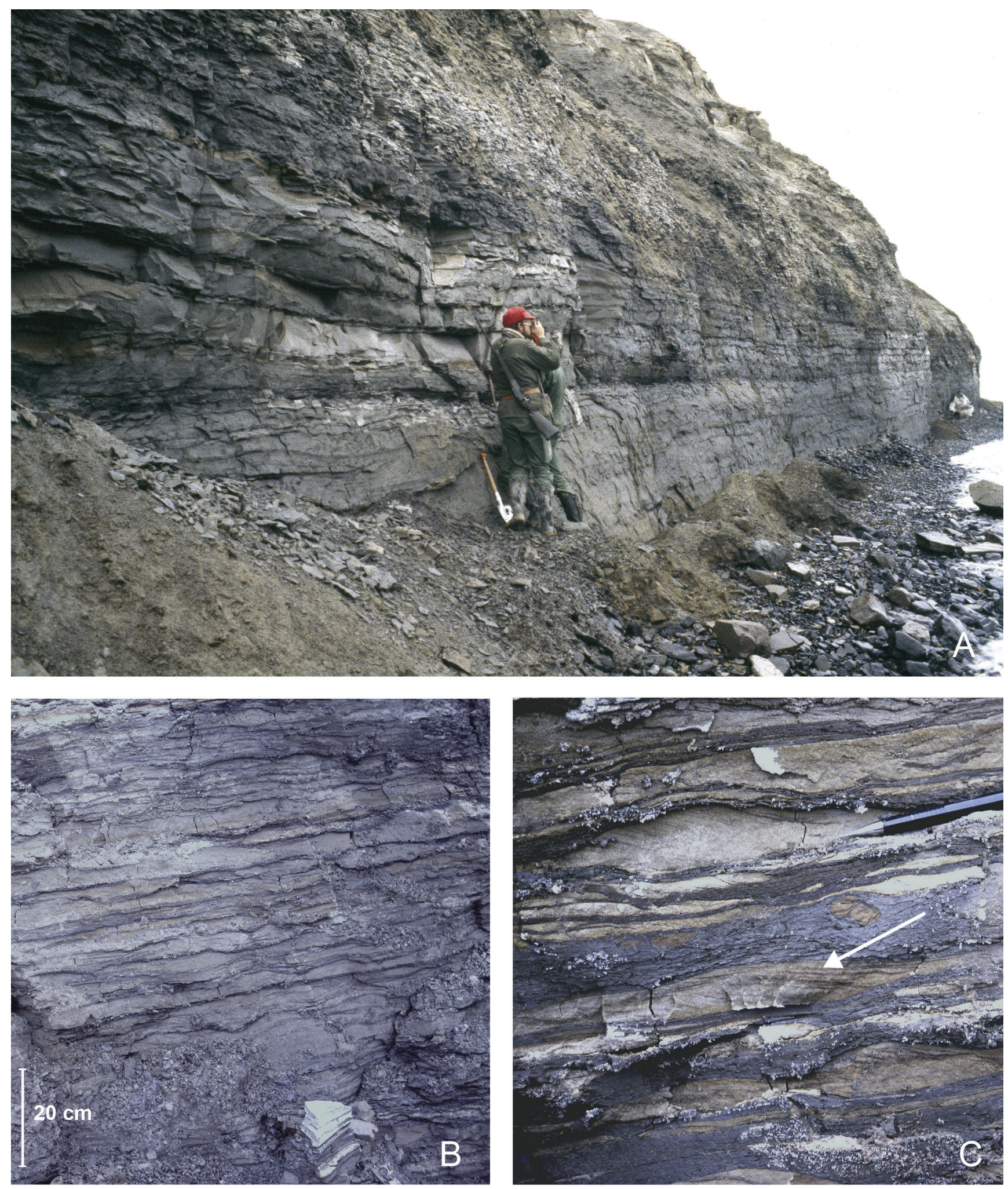

Figure 10. Flatsalen Formation, Kapp Koburg, Kong Karls Land. (A) Tabular geometry of cross-stratified sandstone, FFA-3, from the upper part of the Kapp Koburg log (Fig. 8). Upper part of the photo is covered by Holocene raised beaches. (B) From the middle part of the Kapp Koburg $\log$ showing small CU units with heterolithic mudstone and sandstone beds at base passing upward to lenticular sandstone beds. (C) Detail of combined traction oscillation ripples from middle part of the CU unit. Arrow points to draping laminae above unidirectional current ripples, giving a microhummocky appearance. Pen for scale. 

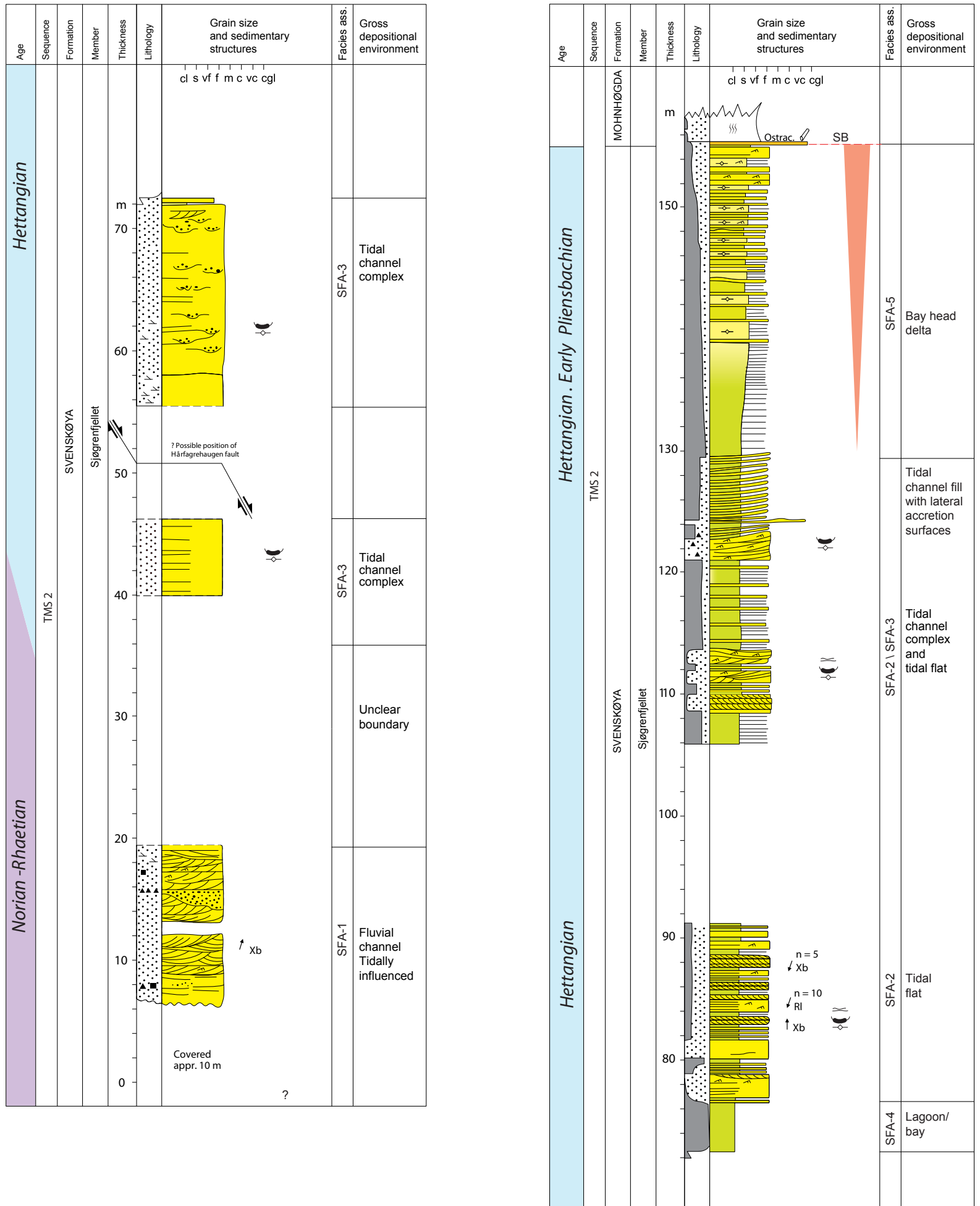

Figure 11. Sjøgrenfjellet Member, Hårfagrehaugen, Kongsøya. For legend see Fig. 22.

of trough cross-stratified, fine- to medium-grained sandstones (Facies 14, Table 1); neither the top nor the base of this facies association is exposed here. Mud pebble conglomerate conglomerates at set boundaries are common. Coal, leaf and wood fragments occur, while burrows were not observed. On Hopen, the base of the Svenskøya Formation is formed by a sharp erosive surface (Figs. 8 \& 9) (Lord et al., in press). This is overlain by a 7-8 m-thick, cross-stratified, coarse- to mediumgrained sandstone (Lord et al., in press).

\section{Interpretation}

Lord et al. (in press) interpreted the basal trough and tabular-stratified sandstone unit of the Svenskøya Formation on Hopen as representing stacked fluvial channels. 
We interpret the trough cross-stratified sandstones, SFA1 , as fluvial deposits. The trough cross-bedded sandstone in the lowermost exposed part in Kong Karls Land also resembles the in-channel fluvial fill at Hopen, and, most likely, also has an erosive surface at the (non-exposed) base.

\section{Facies association SFA-2, tidal flat Description}

Facies association SFA-2 consists of heterolithic deposits (sandstone-shale) and forms 5-15 m-thick tabular units that are interbedded with the tidal channel fill facies association (SFA-3). The association comprises tabular, sometimes wedge-shaped, cross-stratified, finegrained sandstones with common double mud drapes, reactivation surfaces (Facies 10, Table 1) (Fig. 12A, C \& F) and flaser-, wave- and lenticular bedding (Facies 9, Table 1) (Fig. 12D). Set thicknesses of the tabular-stratified sandstones vary from 5-60 $\mathrm{cm}$ with lateral extent of single beds up to at least $10 \mathrm{~m}$ (Fig. 12F). Foresets have tangential lower contacts, in places with back-flow current ripples (Fig. 12A), or they pass into thin muddy bottomsets (Fig. 12C). Bi-directional (herringbonelike) tabular sets are only rarely seen (Fig. 12E). Drapes consist of clay, organic material and coal fragments and vary systematically between thin and thick foreset laminae (Fig. 12A). The cross-stratified sandstones are interbedded with 1-30 cm-thick heterolithic beds which consist of moderately to well-sorted, very fine- to finegrained, white and greyish-white sandstone with parallel lamination, flaser- and lenticular bedding where current ripples dominate.

The heteroliths are commonly arranged in 30-50 $\mathrm{cm}$-thick, upwards-coarsening and -thickening units, with organic-rich claystone at the base followed by lenticular-, wavy- and flaser bedding (Fig. 12D).

Within this facies association a regular alternation between metre thick and few decimetre tabular beds of sub-horizontally laminated sandstones is also observed in some localities (Fig. 12B). A few cm-thick, organicrich, brownish claystones may intersect the regularly laminated sandstones.

Palynomorph assemblages in SFA-2 are dominated by freshwater algae (Botryococcus spp. and Deltioidospora spp) (Smelror et al., 2018).

\section{Interpretation}

Double drapes and reactivation surfaces are typical features of tidal deposits (Davies \& Dalrymple, 2012). These structures, coupled with flaser- and lenticular bedding and dominance of non-marine palynomorphs and limited marine species (Smelror et al., 2018), also point to tidal deposits. Tabular geometries indicate deposition mostly within a non-channellised setting. The well organised CU beds with lenticular-, wavy- and flaser-bedding are not associated with channel forms and are thus interpreted to be deposited on tidal flats (cf., Reineck \& Singh, 1980.). The double mud-draped foresets which are systematically alternating with more muddy, fine-grained, thinner foreset laminae with thicker, cleaner sandstone foresets represent neap and spring as described by Visser (1980).

\section{Facies association SFA-3, tidal channel fill Description}

This association is characterised by metre-scale channelshaped units (Fig. 13A, B, F) with sharp or erosive lower boundaries and sharp or gradual upper boundaries. Locally, lateral accretion surfaces are observed (Fig. 13A, B). Mud pebbles up to $10 \mathrm{~cm}$ in diameter are present in some erosional troughs at the base of these units. SFA 3 consists of either heterolithic sandstone (Facies 9, Table 1) or ii) a more homogenous mud-draped and cleaner sandstone (Facies 10, Table 1). The heteroliths consist of sub-tabular units occasionally seen as up to $5 \mathrm{~m}$-thick FU sets with inclined bedding (Fig. 13A, B). The inclined beds have common flaser and lenticular bedding (Facies 9, Table 1), alternating with brownish-grey claystones (Facies 11, Table 1). The cleaner sandstone channel fill (ii) consists of amalgamated, unidirectional, several decimetre-thick, tabular-stratified beds (Facies 10, Table 1) (Fig. 13C, D, E). This fill is well organised with 10 to $20 \mathrm{~cm}$-thick beds and common mud drapes in their lower parts (Fig. 13D) and common burrows on foresets gradually passing upwards to thicker sets, up to $80 \mathrm{~cm}$, with less muds and no or rare burrows (Fig. 13C). Upper sets show thinner beds and common burrows.

\section{Interpretation}

Lithology, sedimentary structures, biofacies and association to SFA-2 suggest that SFA-3 was deposited in a tidal environment. The heterolithic channel fill with inclined bedding indicates lateral migration, i.e., lateral accretion surface in a meandering tidal channel. The fining-upward character of each inclined bed, with flaser and lenticular bedding in its upper part, is consistent with tidal channel fill (cf., Willies et al., 1999). This heterolithic channel fill probably represents an estuarine point bar. The cleaner channel-fill sandstone beds with amalgamated tabular or wedge-shaped tabularstratification partly fit the description of compound tidal dunes with increasing thickness of the dunes and cleaner sandstone upwards due to gradually increasing tidal current upwards (cf., Ashley, 1990; Dalrymple \& Choi, 2007) or tidal bars (cf., Fenies \& Tastet, 1998). Fenies \& Faugeres (1998) describe from the Gironde estuary a 5 $m$-thick tidal channel with an erosive lower boundary followed by an approximately $1 \mathrm{~m}$-thick coarse-grained sandstone with mud clasts which again is overlain by a 4 to $5 \mathrm{~m}$-thick, unidirectional, cross-stratified sandstone with $30-50 \mathrm{~cm}$-thick dunes. The sharp lower boundary with common mud clast and coal fragments in its lower part suggests that this cleaner channel-fill sandstone body also represents a tidal channel. The thinner beds in its upper part and more common burrows suggest a 

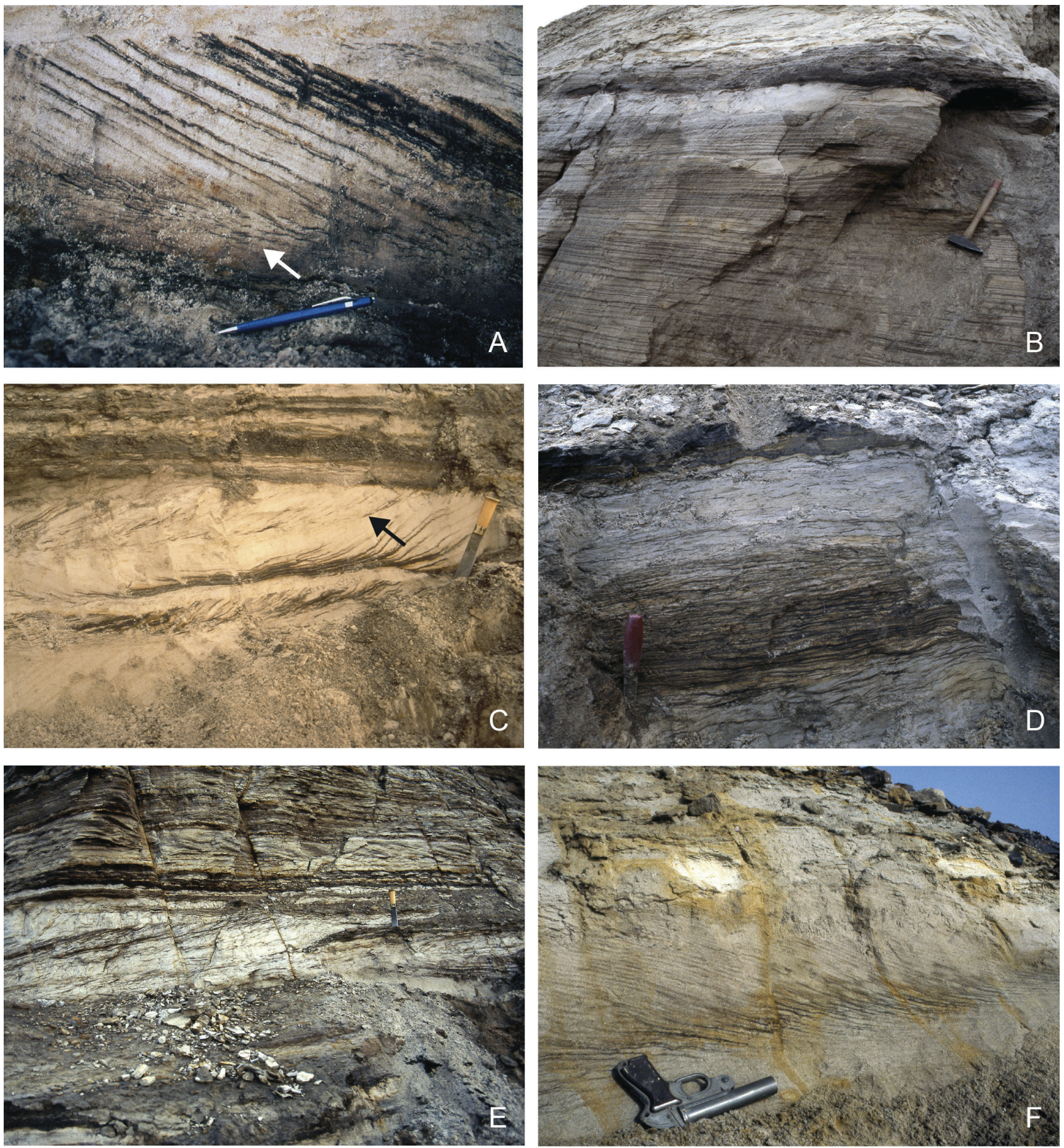

Figure 12. Tidal sedimentary structures from SFA-2. (A) Double-draped, tabular-stratified bed with superimposed counter-flow climbing ripples in the bottomset (arrow). Note thin, bedded, muddy or coaly debris on foresets alternating with coarser and cleaner foresets suggesting variable strength of the tide current, i.e., neap and spring tides, respectively. (B) Cyclic, thin and thick, horizontally laminated heteroliths suggesting tidal bedding. (C) Double-draped, tabular-stratified sandstone beds with reactivation surface (arrow). (D) Wavy bedding in lower part passing upward into lenticular bedding in the middle part which is capped by flaser bedded sandstone. (E) Typical heterolithic facies of tidal flat deposits. Lower sandstone shows dominating current to the left while dunes in the middle part are directed to the right. The dunes represent flood and ebb flow. (F) Laterally extensive, mud draped cross-stratification with systematic thick and thin foresets in a dune as a response to neap and spring tides.

waning of the tidal currents. The unidirectional crossstratified sandstones were deposited as dunes along the channel base, related either to ebb or flood tidal currents. In summary, we interpret the cleaner and amalgamated sandstone body as a subtidal channel fill.
Facies association SFA-4, lagoon

\section{Description}

This facies association occurs in the middle part of the Sjøgrenfjellet Member and consists of a 4 m-thick brown claystone bed (Facies 11, Table 1) resting on white 

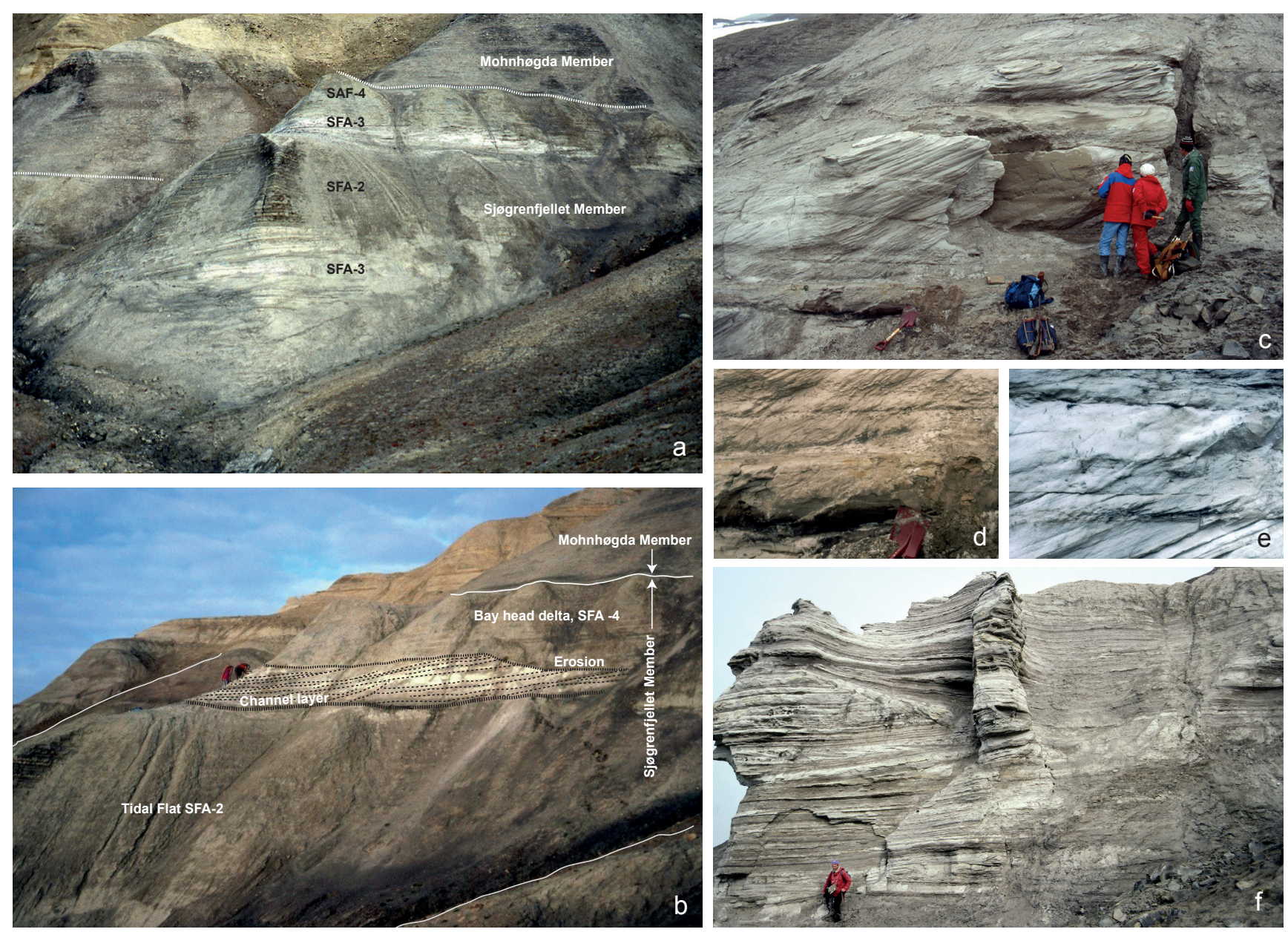

Figure 13. Tidal channel fills from Hårfagrehaugen. (A) Channel complexes (SFA-3) interbedded with tidal flat deposits of SFA-2. (B) Heterolithic tidal channel fills showing lateral accretion surfaces which are cut by an erosive surface. (C) Close-up of base of lower channel complex with amalgamated $2 D$ dunes, probably representing an estuarine channel with either ebb or flood tidal bars, note gradual thickening of cross beds. (D) Basal part showing erosive surface of coaly shale and thinner beds and burrows. (E) Upper part of channel fill with increased frequency of burrows on top. (F) Heterolithic tidal channel in the same stratigraphic level as the channel in 13B.

sandstones belonging to SFA-2. The claystone is mostly structureless, tabular in shape and with a relatively consistent thickness when traced laterally. The bed can be correlated from Hårfagrehaugen to Retziusfjellet on Kongsøya (Fig. 14A). Scattered brackish to freshwater palynomorphs are present in SFA-4 (Smelror et al., 2018).

\section{Interpretation}

Lack of characteristic sedimentary structures makes the interpretation somewhat speculative. However, the biofacies which suggests brackish water, the lateral extent and the association with tidal deposits above and below may suggest a tidal depositional environment also for SFA-4. The fine-grained lithology suggests deposition from suspension in a standing body of water, and SFA-4 is interpreted as the infill of a widespread low-energy environment such as protected parts of an estuarine basin or in a protected bay/lagoon.
Facies association SFA-5, bay-head delta

\section{Description}

This facies association is only observed in the upper part of the Sjøgrenfjellet Member and consists of a 23 m-thick heterolithic CU unit (Fig. 11). The facies is generally coarser grained at Retziusfjellet than on Hårfagrehaugen (Fig. $14 \mathrm{~A}$ ). The lower part of the CU unit is dominated by mudstone with a $50 \mathrm{~cm}$-thick, black, organic-rich, paperlaminated claystone at its base (Facies 1, Table 1) which grades up into laminated brownish-black claystone (Facies 2, Table 1) with thin siltstone and sandstone beds at Hårfagrehaugen, or alternating greyish-black silty clay and greyish-white sandstones at Retziusfjellet. The sandstone beds become thicker bedded upwards. Horizontal lamination and diffuse ripple lamination is observed in thicker silt- and sandstone beds. The upper parts of the CU unit of SFA-5 are commonly ripple laminated with wavy-, lenticular- and flaser bedding (Facies 9, Table 1) intersected by the tabular-stratified sandstone with similarities to sandstone beds in SFA-2 


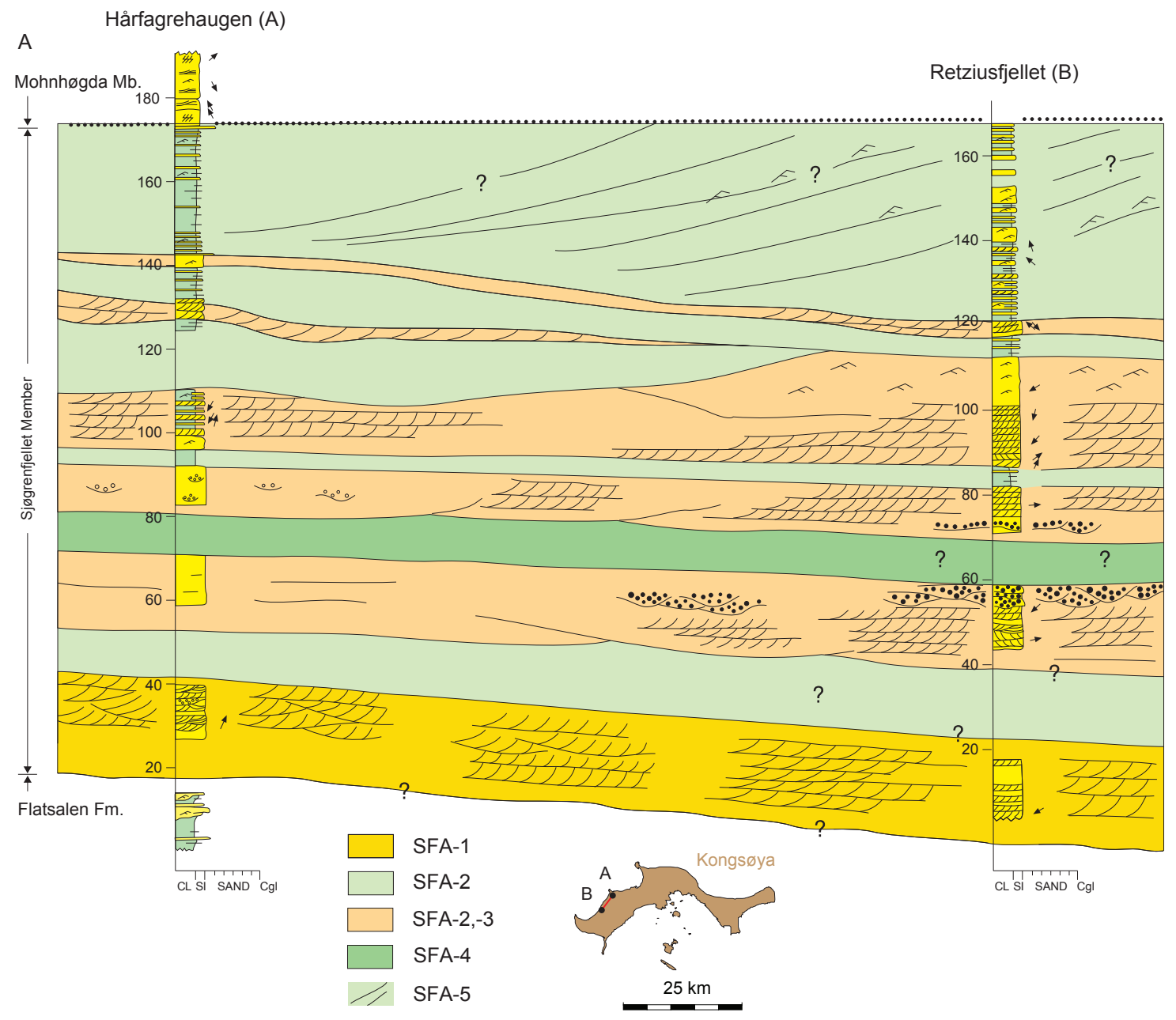

B

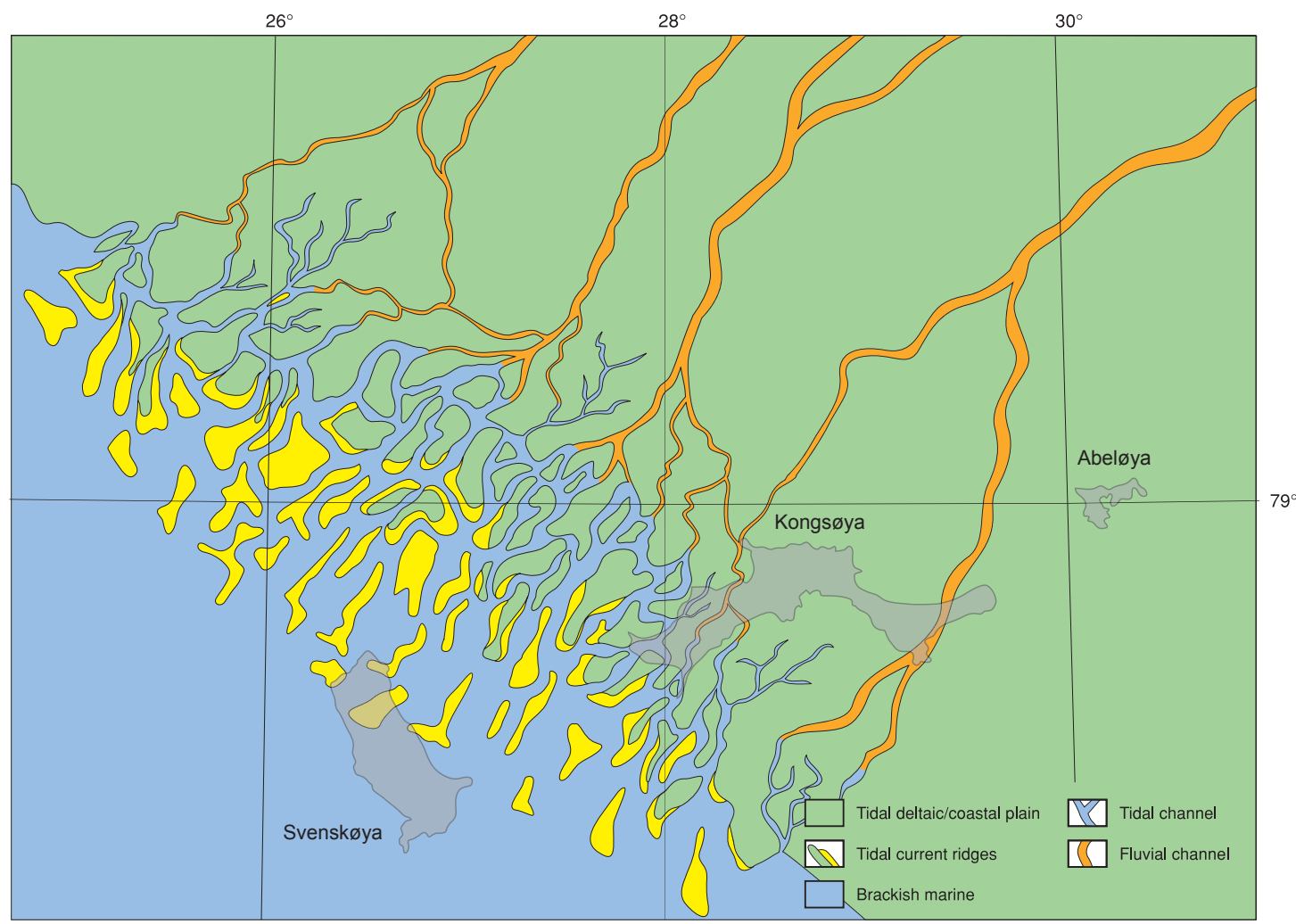

Figure 14. Sjøgrenfjellet Member. (A) Correlation of the member within northeastern Kongsøya. (B) Conceptual palaeogeography of the member. 
and 3 (Facies 10, Table 1). Facies association SFA-5 was only observed in two laterally extensive and correlative benches at Hårfagrehaugen and Retziusfjellet, where the facies shows large-scale subtabular to weakly troughshaped geometries with locally erosive bases. The upper part of this facies association exhibits very low-angle 5 m-thick clinoforms.

\section{Interpretation}

The similarity to SFA-2 indicates a tidal origin also for SFA-5, while the well organised CU suggests progradation. The low-angle inclined bedding (i.e., clinoforms ) in the upper part (Fig. 14) points to a prograding delta or shoreline. The organic-rich paper shale at the base and the association with tidal facies associations may represent infill of a stagnant brackish estuarine water body (cf., Dalrymple et al., 1992) or alternatively of an interdistributary bay. The dominance of tidal as opposed to wave-generated structures suggests a protected environment. Although associated fluvial or distributary channels cannot be demonstrated, we suggest SFA-5 to represent the distal part of a bay-head delta gradually infilling an estuary. A similar heterolithic CU unit from the Campanian Middle Castlegate Sandstone (Book Cliffs, Utah) was interpreted as a bayhead delta deposit (Ashcoff et al., 2017).

Summary of the depositional environments of the Siøgrenfjellet Member

The facies associations of the Sjøgrenfjellet Member can be placed within a tidal delta or an estuarine depositional environment (cf., Dalrymple \& Choi, 2007). Generally, this is best demonstrated on Kongsøya, where the lower part of the Sjøgrenfjellet Member, with a fluvial influenced channellised association, represents the inner part of an estuary or a distributary channel in a tidal delta. Also, the proposed bay-head delta environment of SFA-5 is suggested to be found within an inner estuary. The proposed tidal channel environment of SFA-2 and tidal-flat environment of SFA-3 is suggested to represent an inner or middle estuary. The mudstone of SFA-4 is interpreted as an estuary or bay fill. The majority of sedimentary structures are tidally induced, suggesting a tidally dominated estuary. A $5 \mathrm{~km}$ crosssection in the eastern part of Kongsøya reveals a near layer-cake distribution of the facies associations (Fig. 14A). Palaeocurrent measurements in SFA-3, especially in the middle part of the member, show a large spread, but readings are more uniform within each individual sandy unit. A bimodal palaeocurrent distribution is observed in cross-strata at several localities. The most common palaeocurrent trends are bimodally directed towards the SW and NE. Fig. 14B shows the proposed palaeogeography of the Sjøgrenfjellet Member.

\section{The Upper Pliensbachian-Middle Toarcian Mohnhøgda Member}

The 45 to 55 m-thick Mohnhøgda Member has its base defined by a laterally persistent poorly sorted gravel bed with quartz grains and shell fragments of ostracods and is interpreted as a transgressive lag (Facies 4 in Table 1) (Fig. 15).

The member is dominated by white and yellow finegrained sandstones with interlaminated dark grey and brownish-grey clay- and siltstone and organic material. Generally, there are no clear fining or coarsening upwards trends. The thickest sandstone units can be traced laterally for hundreds of metres. Three facies associations have been identified in the Mohnhøgda Member.

\section{Facies association MFA-1, shoreface \\ Description}

Facies association MFA-1 consists of very fine-grained, decimetre-thick sets of hummocky cross-stratified to horizontally laminated (Facies 6, Table 1) or bioturbated sandstone beds (Facies 7), reaching up to $10 \mathrm{~m}$ in total thickness (Figs. 15 \& 16A). The hummocky crossstrata show wavelengths from $50 \mathrm{~cm}$ to several metres. Occasional thin polymict gravel lags (quartz, siderite and wood fragments) are seen at the base of the hummocky cross-stratified sandstone beds (Fig. 15). Laminae within the hummocks commonly show double mud drapes (Fig. 16B, C). The hummocky cross-stratified sandstone beds are capped by, or gradually pass upward into current ripples or combined wave/current ripples. Both the hummocky cross-stratified and the laminated sandstone beds are moderately bioturbated and often amalgamated (Fig. 16A) The intensely bioturbated $<10$ m-thick, very fine-grained sandstone beds, which contain Ophiomorpha, Chondrites, Rosselia, Rhizocorallium, Teichichnus and Arenicolites burrows, suggest a mixed Skolithos and Cruziana ichnofacies and interfinger laterally with the hummocky cross-stratified and horizontally laminated sandstones. Palaeocurrent measurements suggest a more northerly drainage area and an E-W oriented coastline for MFA-1 than for the underlying Sjøgrenfjellet Member.

\section{Interpretation}

Hummocky cross-stratification is interpreted to be formed by combined flow processes associated with storm waves (Swift et al., 1983; Dumas \& Arnott, 2006; Dumas et al., 2005). The centimetre to metre-thick hummocky cross-stratified sandstones interbedded with mudstones are interpreted to be deposited in the transition between shoreface and offshore in a prograding shoreline (cf., Cheel, 1991). Double muddrapes may indicate some tidal influence. Mud drapes in hummocks have also been reported from tidally influenced shoreline environments by Yang et al. (2008). 


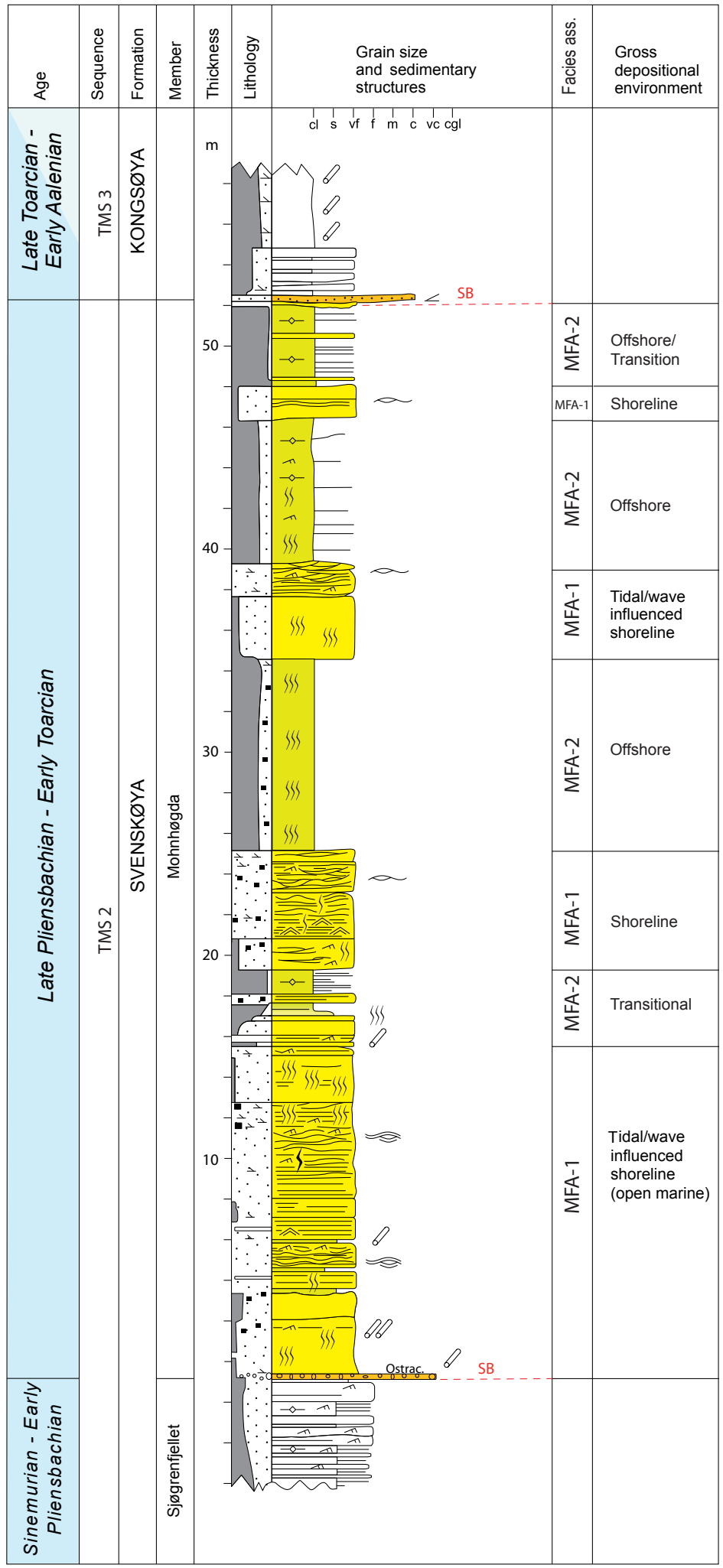

Figure 15. Log of the Mohnhøgda Member. Hårfagrehaugen, Kongsøya. For legend see Fig. 22.

The completely bioturbated sandstones suggest periods with no or slow sedimentation. In summary, facies association MFA-1 is interpreted to have been deposited in a shoreface environment. The occurrence of Ophiomorpha, lack of high-angle cross-stratification, common burrowed beds and mixed Cruziana and Skolithos ichnofacies, suggest a lower to middle shoreface setting (cf., MacEachern et al., 2010). 

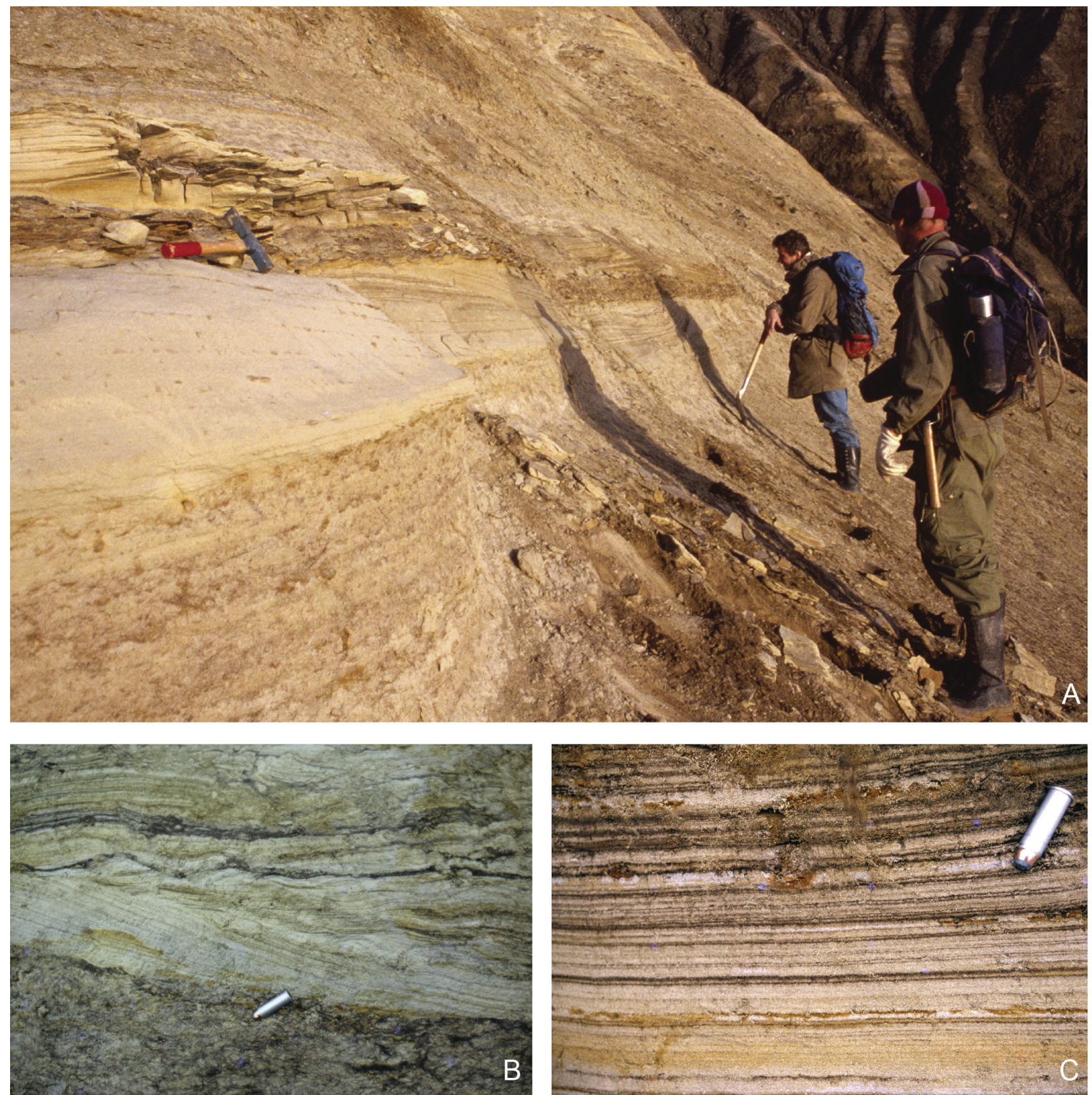

Figure 16. Mohnhøgda Member, MFA-1. (A) Burrowed sandstone with common Ophiomorpha trace fossils passing upward to hummocky cross-stratified sandstone, which is overlain by heteroliths. The bed above the hammer is carbonate-cemented and stands out in the otherwise unconsolidated sandstone. (B) Hummocky cross-stratified bed followed by wave ripples. (C) Double drapes in hummocky cross-stratified beds. Location: Hårfagrehaugen.

Facies association MFA-2, offshore transition zone Description

Heterolithic beds with grey, dark grey and brownish clayand siltstones and yellow and white very fine-grained sandstones (Facies 9, Table 1) are the main constituents of facies MFA-2 (Fig. 16A). Dark grey and brown to black organic particles are also common. The heterolithic beds occur in up to $10 \mathrm{~m}$-thick tabular units with lateral extents of at least hundreds of metres. The deposits are commonly structureless, with a mottled appearance due to bioturbation, except for local 1-3 cm thick sub- horizontal beds of fine-grained sandstones, sometimes with flaser or wavy bedding (Facies 9, Table 1). The ratio of sand to clay/silt varies.

\section{Interpretation}

The sediments of MFA-2 were mainly deposited in lowenergy conditions, probably sporadically influenced by large waves or tides depositing the thin storm- and tidally deposited beds which were later reworked by bioturbation. The interfingering relationship to facies MFA-1 suggests a lower shoreface to offshore transition 
zone environment. An increase of MFA-2 at the expense of MFA-1 is thought to reflect an increase in water depth.

Facies association MFA-3, incised valley fill; bay, delta-front and distributary channels

\section{Description}

This facies association is only observed on Kükenthalfjellet, where it is exposed in a $700 \mathrm{~m} \mathrm{~N}-\mathrm{S}$ oriented section (Fig. 17). It is bounded above by the regionally correlative basal conglomerate (Fig. 17) (Facies 4, Table 1) of the Kongsøya Formation. MFA-3 overlies a thinly bedded conglomerate bed in the south and a coarsegrained cross-stratified sandstone bed in the north. The conglomerate and coarse-grained sandstone have sharp boundaries to offshore transition zone deposits of MFA2. In the south, above the conglomerate, MFA-3 occurs as a near $5 \mathrm{~m}$-thick $\mathrm{CU}$ unit with dark grey mudstone (Facies 2, Table 1) (Fig. 17A, C) passing upward to finegrained sandstone. The northern outcrop consists of four, stacked, 1-2 m-thick CU units with extensively bioturbated mudstones at the base, which gradually pass upwards to very-fine grained wave- or current ripplelaminated sandstones (Facies 9, Table 1) (Fig. 17B, C).
In southern exposures, a 50-100 m-wide and up to 4 $\mathrm{m}$-thick channel-shaped massive sandstone unit cuts the muddy CU unit (Fig. 17). The $4 \mathrm{~m}$-thick sandstone has a subtle FU trend with white to greyish-white, medium- to fine-grained, tabular and trough crossstratified sandstones (2D 3D dunes) (Facies 13, 14, Table 1). These sandstones are locally floored by a gravel lag with trough cross-stratification dominating its lower part and tabular-stratification with set thicknesses from 20 to $50 \mathrm{~cm}$ with organic materials draping the foresets in its upper part. Some mud-draped tabular-stratified beds are seen in the uppermost part of the channellised sandstone unit. The channel-shaped massive sandstone unit thins rapidly when traced laterally, from a maximum of $4 \mathrm{~m}$ to $70 \mathrm{~cm}$. The channel flanks show a finer grain size, but mud clasts and coal fragments may occur. The channel flanks also have a sharp base, but with a finer grain size. While the palynofacies show a mixture of terrestrial and marine facies, with more marine influence in the sandstones than the mudstone, there is a dominance of bisaccate pollen with up to $80 \%$ of the total macerals in the mudstone.
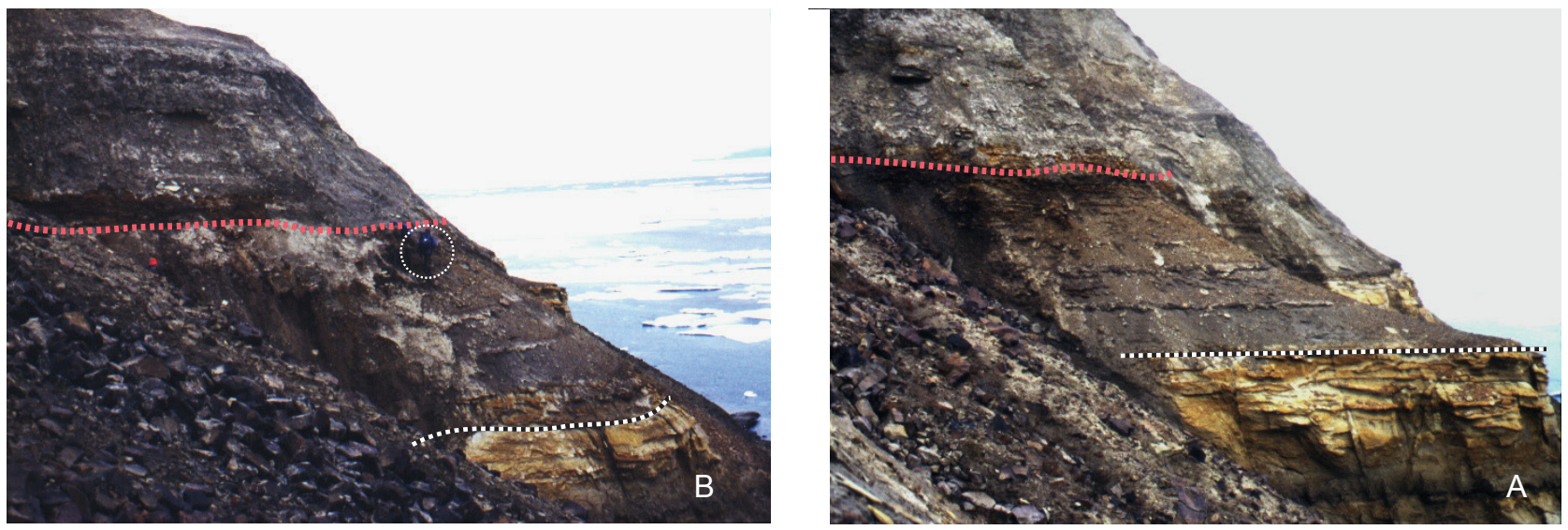

A

Profile Kükenthalfjellet South

B

Profile Kükenthalfjellet

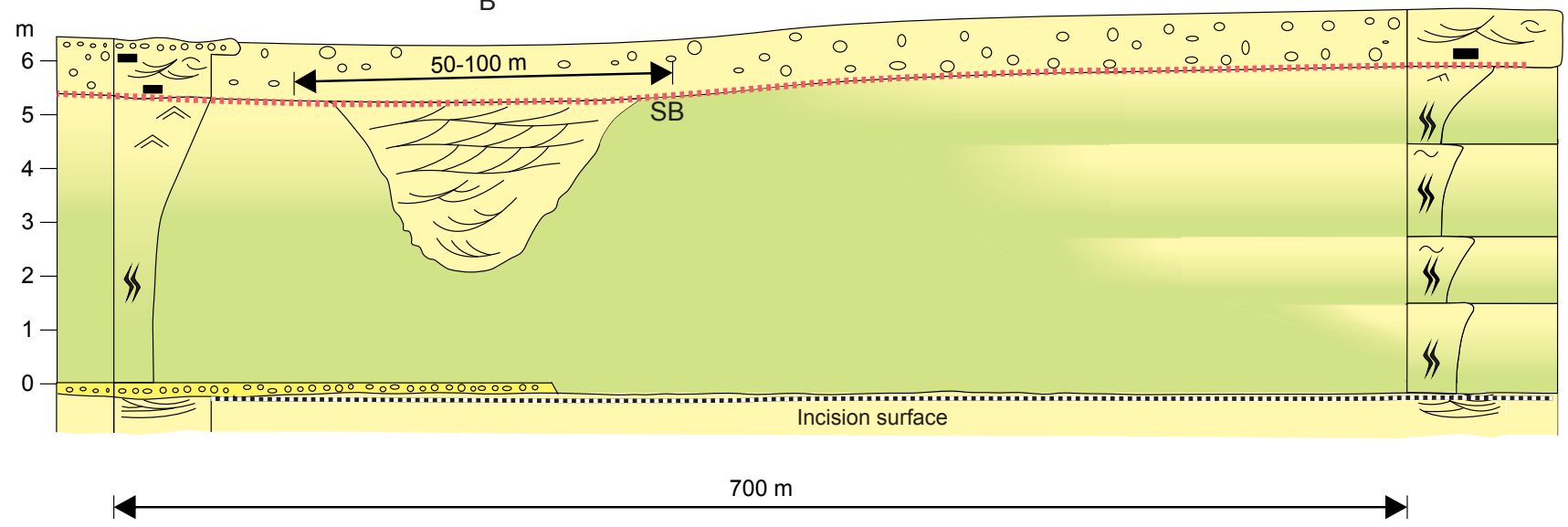

Figure 17. Upper part of the Mohnhøgda Formation, MFA-3 at Kükenthalfjellet. (A) White coloured channelised sandstone is visible below the red stippled line. (B) Shows CU units sandwiched between the red and the white stippled lines. (C) Cross-section between the two localities, A and B, and between the two logged sections. See also log correlation in Fig. 18. For legend see Fig. 22. 


\section{Interpretation}

MFA-3 is clearly distinguished from facies associations MFA-1 and MFA-2 by its well organised CU units and the channellised sandstone. The base of MFA-3 is marked by conglomerate and medium-grained sandstone beds and suggests an abrupt change in facies from the underlying lower shoreface and offshore transition zone of facies associations MFA-1 and 2. This boundary is interpreted as an unconformity surface and is suggested to represent the erosive base of an incised valley (Figs. 17 \& 18).

In summary, MFA-3 is interpreted as representing inner estuarine deposits in a bay-head delta including stacked bay-head delta fronts (mouth bars) and a distributary channel. The dominance of bisaccate pollen (Smelror et al., 2018) is consistent with a more protected inshore depositional environment.

The CU units with current or wave ripples in their upper parts are interpreted as remnants of prograding mouth bars or bay fills.

In the upper part of MFA 3, the local scouring channelfill sandstone with a gravel lag suggests a fluvial channel fill deposited from a high-energy stream flow (Allen, 1983). The slightly fining upwards from trough crossstratified sandstone without marine indicators to more muddy tabular-stratified sandstones with mud drapes indicates some tidal influence.

Summary of the depositional environment of the Mohnhøgda Member

The Mohnhøgda Member shows combined tidal and wave-generated structures. This suggests a shoreface depositional environment, or alternatively, the outer part of a wave-dominated estuary. The bay-head delta MFA-3 on Kükenthalfjellet has a sharp lower boundary to shoreface deposits (MFA-2), in places with a conglomeratic lag at the base and is interpreted as incised valley fill. A correlation of the member between the islands also shows a near correlative layer-cake stratigraphy, suggesting that this represents a strike section of the shoreline (Fig. 18A). A conceptual model of the depositional environment of the lower part of the member is shown in Fig. 18B.

\section{The Upper Toarcian-Aalenian Kongsøya Formation}

The upper Toarcian-Aalenian Kongsøya Formation varies in thickness from $25 \mathrm{~m}$ to around $40 \mathrm{~m}$ and shows an overall upward-fining trend. Grey to bluish finegrained sandstones are developed at the base. These sandstones grade upwards into carbonate-rich siltand sandstones with abundant fossils, and mudstones with concretions (Figs. 19 \& 20). The formation thins and becomes muddier towards the northeast (Fig. 21). The Kongsøya Formation displays three main facies association, all suggesting slow sedimentation rates or even condensation.

Facies association KFA-1, transgressive lag, offshore transition zone

\section{Description}

KFA-1 occurs in the lower and upper parts of the Kongsøya Formation. The dominant lithology is a structureless muddy sandstone with scattered glauconite and gravel grains. It has a heterolithic nature with faint interbedded mudstone and very fine-grained sandstone. In lower exposures it displays a basal conglomeratic bed (Facies 4, Table 1) passing up to very fine-grained, bioturbated muddy sandstone with scattered glauconite grains (Facies 3, Table 2), (Fig. 19A). The conglomeratic bed consists of a $5 \mathrm{~cm}$-thick siderite bed followed by a 2-3 cm-thick mudstone bed and $5 \mathrm{~cm}$ of quartz and chert-rich gravel with wood fragments and siderite pebbles. Above this follows a $10 \mathrm{~cm}$-thick sandstone bed with patchy assemblages of glauconite grains or, in some localities, a $25 \mathrm{~cm}$-thick glauconite bed (Facies 3, Table 1). The patchy character of the glauconite probably reflects sediment redistribution by burrowing animals. Plant fragments and bioturbation are common. In some areas in the upper part of the formation, a single carbonate-cemented, hummocky cross-stratified, very fine-grained sandstone bed (Fig. 19B) (Facies 6, Table 1) is seen. Scattered occurrences of nodular siderite layers and concretions contain recognisable plant, coal and brownish wood fragments. The trace fossil Teichichnus dominates, while Rhizocorallium and Arenicolites occur sporadically. KFA-1 is up to $6 \mathrm{~m}$ thick.

\section{Interpretation}

The basal conglomerate lag, with glauconite and marine burrows overlying fluvial and tidal deposits of the Mohnhøgda Member, suggests a transgressive development above a subaerial unconformity surface. The common occurrence of facies 3 suggests an offshore environment, and the association was probably deposited during periods with slow sedimentation rates. The single, calcite-cemented, hummocky cross-stratified sandstone indicates deposition near or at storm-weather wave base. The thin sandstones that are interbedded with the mudstone in the lower part of the Kongsøya Formation might represent periodic distal storm beds in an offshore transition zone, which later were reworked by intense bioturbation. The high content of marine microplankton and fewer bisaccate pollen and cuticula fragments compared with underlying beds (Smelror et al., 2018) is consistent with deposition in a more open marine environment than the underlying paralicdominated facies associations. The presence of a trace fossil assemblage attributed to the Cruziana ichnofacies, which is common in sediments deposited below fairweather wave base in normal marine water and on a well-oxygenated sea floor (MacEachern et al., 2007), is in line with an interpretation of KFA-1 as representing a transition to an offshore depositional environment. 

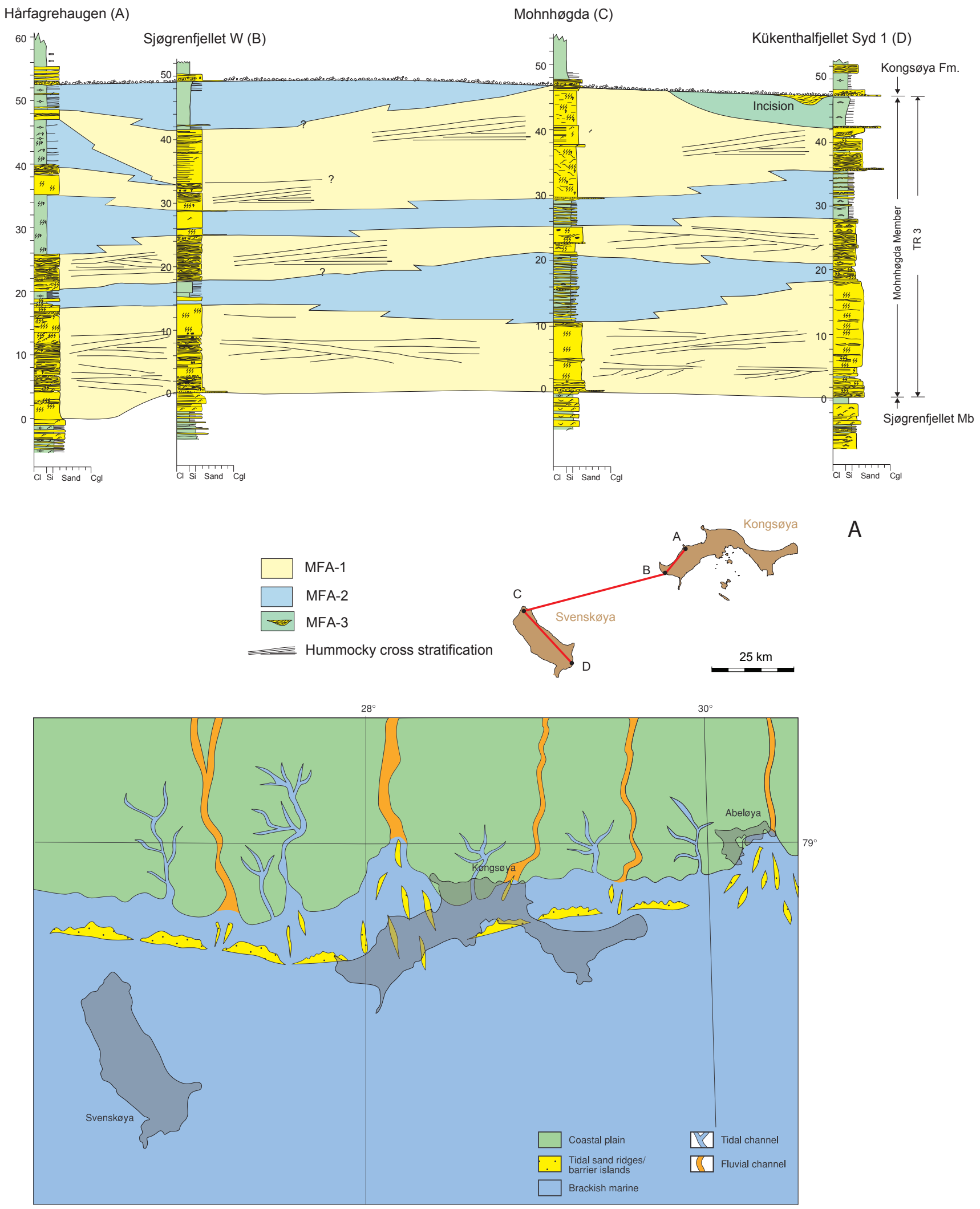

Figure 18. (A) Correlation of the Mohnhøgda Member in Kong Karls Land. (B) Palaeogeographic reconstruction of the lower part of the Mohnhøgda Member. 


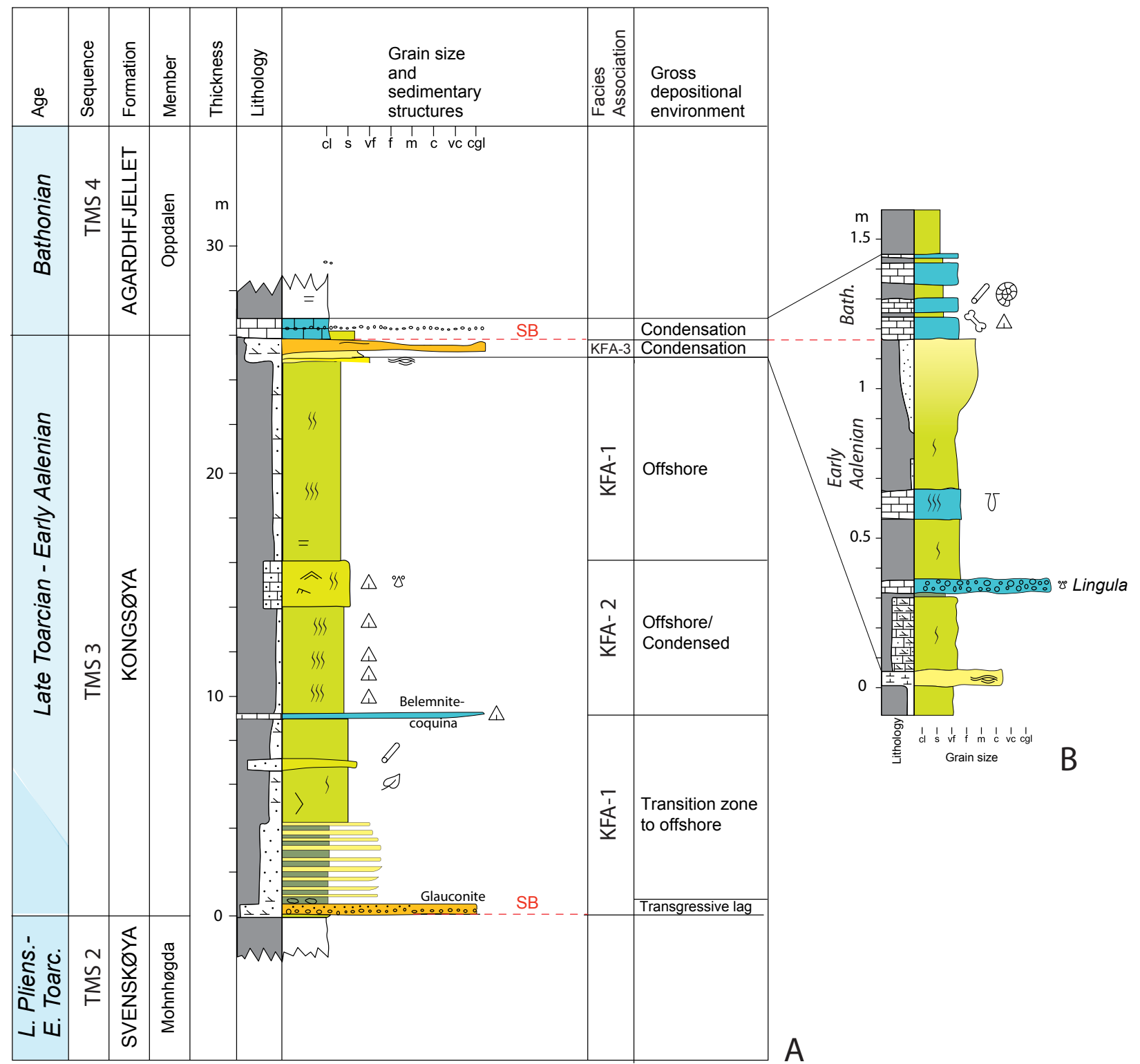

Figure 19. (A) Log of the Kongsøya Formation. (B) Close up of the boundary between the Kongsøya and Agardhfjellet formations. Locality: Sjøgrenfjellet, Kongsøya For legend see Fig. 22.

Facies association KFA-2, condensed offshore transition

\section{Description}

Wherever the Kongsøya Formation is exposed on Kong Karls Land, this facies association is easily recognised by the abundance of numerous belemnites (see also Doyle, 1987), either concentrated in shell beds (i.e., coquinas) up to $20 \mathrm{~cm}$ thick (Fig. 20B) or scattered throughout. Up to 6 beds of well-preserved belemnites are seen in this facies association. The belemnite beds (Facies 5, Table 1) are occasionally accompanied by glauconite grains. Apart from belemnites, bivalves are also common in this association. While most belemnite beds float in a muddy matrix, a few beds are graded resembling coquinas. The host rock consists of burrowed mudstone and siltstone and rare very fine to fine-grained sandstone with a few observed wave ripples (Facies 2, Table 1). A 2 m-thick bioturbated calcite-cemented sandstone bed (Facies 2, 7, Table 1) of this association in the middle part of the Kongsøya Formation (the Bogen Bed of Smith et al., 1976) is laterally extensive throughout Kong Karls Land.

\section{Interpretation}

The widespread occurrence of belemnites (Doyle, 1987), extensive burrowing and common glauconite reflects minimal sedimentation rates. Most of the beds including coquinas were probably deposited as storm beds, and later reworked by bioturbation. An offshore transition, condensed depositional environment is suggested for KFA 2. 

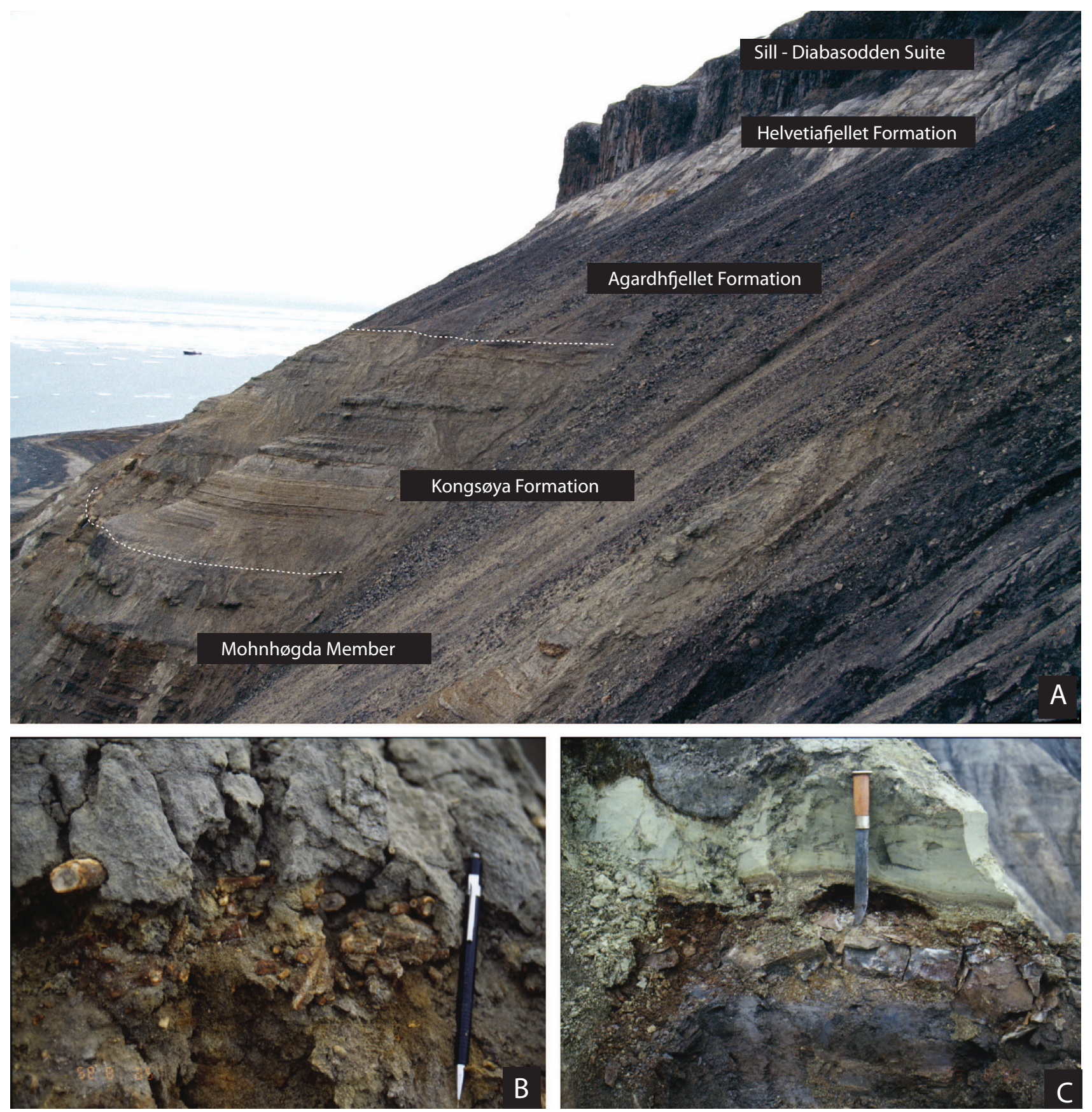

Figure 20. Kongsøya Formation. (A) The formation cropping out on Kükenthalfjellet, Svenskøya, where the formation is $25 \mathrm{~m}$ thick. (B) Belemnite bed within heterolithic facies association, KFA-3, locality Kükenthalfjellet, Svenskøya. (C) Level of basal conglomerate of the Kongsøya Formation recognised throughout Kong Karls Land, locally capped with an up to $25 \mathrm{~cm}$-thick glauconite bed, location Hårfagrehaugen, Kongsøya.

Facies association KFA-3, condensed shelf

KFA-3 occurs in the upper part of the Kongsøya Formation. Wherever observed in Kong Karls Land the facies association is developed as an approximately one metre-thick unit. At Hårfagrehaugen it is $1.2 \mathrm{~m}$ thick and consists of carbonate-cemented, weakly bioturbated, very fine-grained sandstone (Facies 7 , Table 1) at the base followed by a $30 \mathrm{~cm}$ intraformational carbonate breccia (Facies 5, Table 1) with Skolithos burrows (Fig. 20C). The clasts in the breccia consist of carbonates and broken fossil fragments. Lingulid brachiopods are common.
Above the breccia follows a $20-30 \mathrm{~cm}$-thick mudstone capped by sandy limestone with no macrofossils or sedimentary structures. The upper part is a coarseningupward unit with mudstone passing upwards into coarsegrained muddy sandstone (Facies 2, 7, Table 1) (Fig. 19B). However, the vertical order of lithologies within this association shows significant lateral variation, i.e., the carbonate breccia may occur in the uppermost part. Also, highly fractured siderite beds are observed in the upper part. Borings have been observed in the carbonate beds at a few localities. 


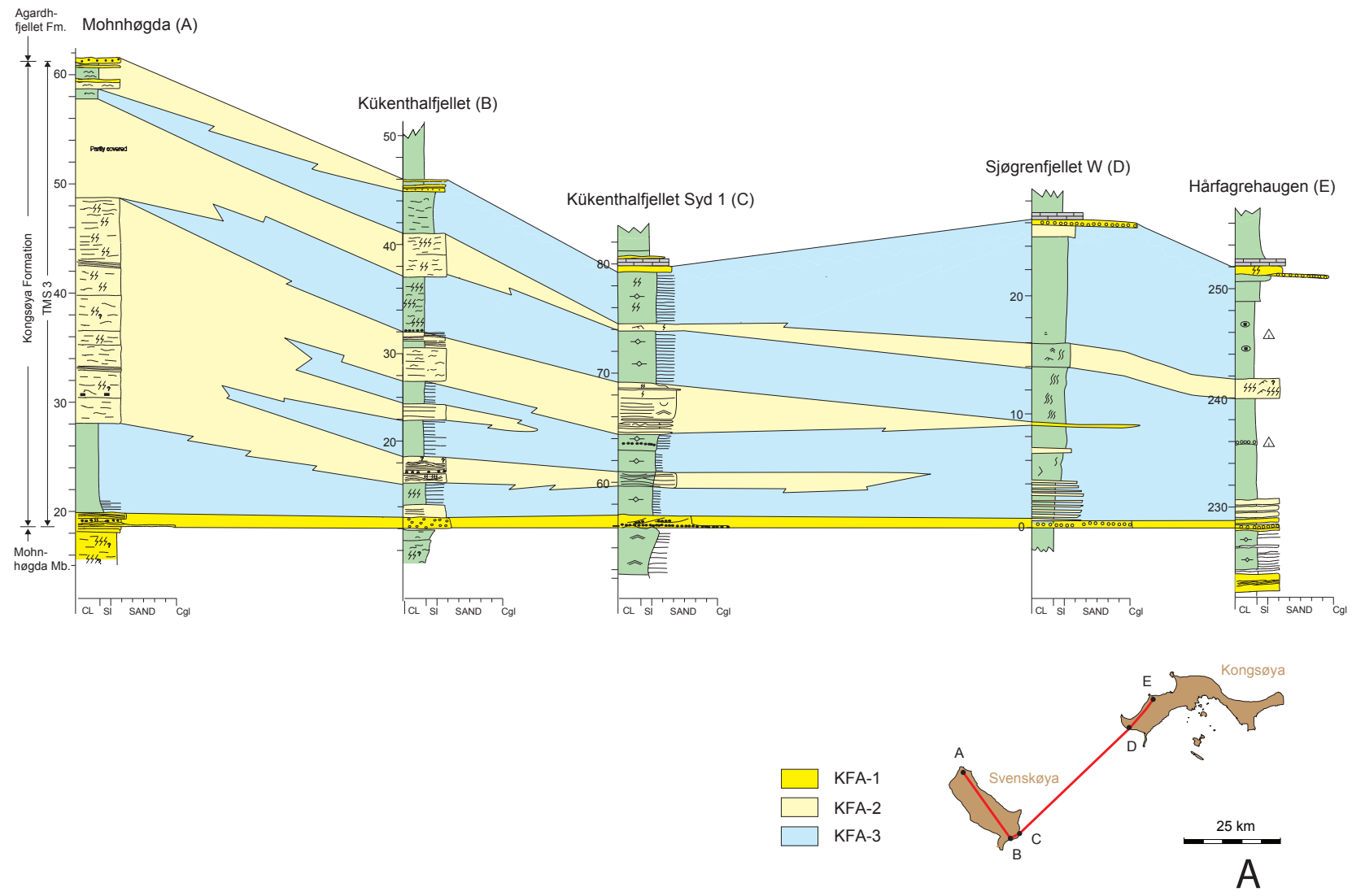

$28^{\circ}$

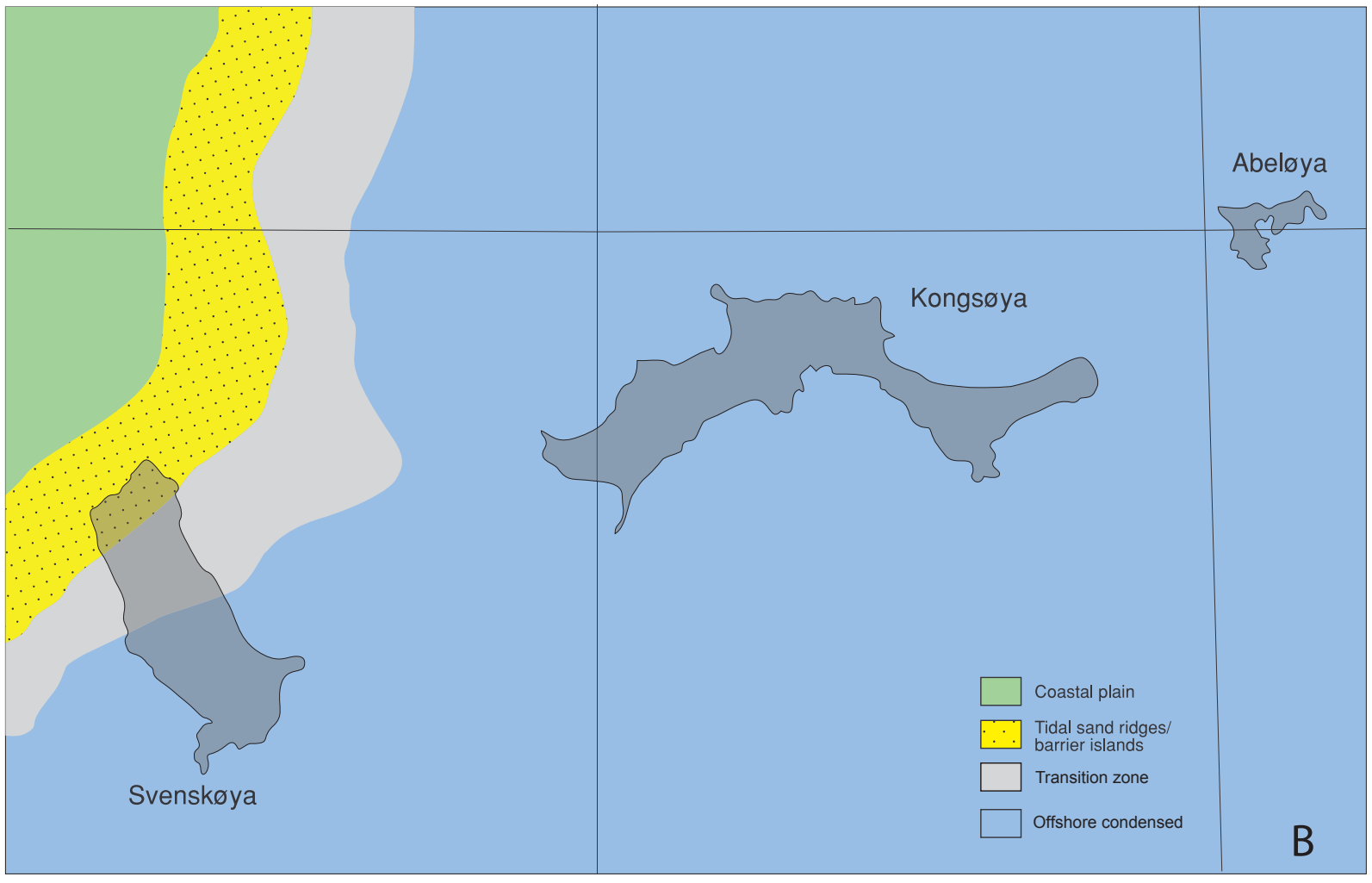

Figure 21. (A) Correlation of the Kongsøya Formation in Kong Karls Land. Note the thicker sandstone beds in the west. (B) Palaeogeographic reconstruction of the Kongsøya Formation. 


\section{Interpretation}

KFA-3 shows evidence of a condensed facies. The breccia may result from either subaerial exposure of a carbonate bed or erosion of a shallow-marine hardground. The occurrences of borings in some of the carbonate beds indicate hardgrounds. The lateral variation of the upper part might indicate an erosive surface. Throughout Svalbard the uppermost Toarcian to Bathonian part of the Wilhelmøya Subgroup displays hiatuses, condensation and erosive surfaces (Bäckstrøm \& Nagy, 1985; Rismyhr et al., 2019).

On Spitsbergen, the subgroup is capped by a polymictic fossiliferous glauconitic conglomerate with phosphate, quartz, chert and basement pebbles assigned to the Brentskardhaugen Bed (Bäckstrøm \& Nagy, 1985; Mørk et al., 1999). This bed is interpreted as a remanie conglomerate with condensation of Toarcian-Aalenian sediments. Possible reworked Bajocian bivalves and Bathonian foraminifera suggest that the Brentskardhaugen Bed represents reworked units deposited in the Bathonian (Bäckstrøm \& Nagy, 1985). A cored section in the vicinity of Longyearbyen shows several stratified conglomeratic beds within the Brentskardhaugen Bed interpreted to represent ravinement surfaces separating a series of ToarcianAalenian high-frequency sequences (Rismyhr et al., 2019). This conglomerate has so far not been observed in Kong Karls Land.

Summary of the depositional environment of the Kongsøya Formation

The sediments of the Kongsøya Formation (KFA-2 \& 3) show strong evidence of offshore to inner shelf marine condensed conditions. A correlation of the Kongsøya Formation (Fig. 21A) gives a somewhat different trend to that of the Svenskøya Formation. The more sandstone-prone facies in the west may suggest a shift from a northerly to a more westerly or northwesterly provenance area (Fig. 21B) (Rismyhr et al., 2019). Also, on Wilhelmøya the Kongsøya Formation shows a more proximal facies than on Kong Karls Land (Mørk et al., 1999).

\section{The Bathonian-Lower Kimmeridgian Agardhfjellet Formation}

With no Volgian and Ryazanian deposits present (Smelror et al., 2018), only the lower parts of the Agardhfjellet Formation are preserved in Kong Karls Land. The up to $70 \mathrm{~m}$-thick deposits were subdivided by Mørk et al. (1999) into two members: a lower Bünsowbukta Member and an upper Høgsletta Member. Previously, Smith et al. (1976) assigned this succession to the Retziusfjellet Member of the Kongsøya Formation and recognised ammonites of Middle Bathonian age in the basal beds, Middle to Late Callovian assemblages higher in the member, and Early Oxfordian and Early
Kimmeridgian faunas in its uppermost parts. In this study, due to near similarity in age and identical lithology, we have assigned the two members of the Agardhfjellet Formation to the Oppdalen and Lardyfjellet members (Fig. 22) as defined on Spitsbergen (Dypvik et al., 1991a; Mørk et al., 1999). In central Spitsbergen, where the succession is complete, Koevoets et al. (2018) described six TR sequences in the formation. The formation is either overlain by the Valanginian Tordenskjoldberget Member with a major hiatus in between, or it is erosively truncated by the Barremian/Aptian Helvetiafjellet Formation.

The exposed units are subdivided into four palynological zones, the two lower zones within the Bathonian to Lower Callovian Oppdalen Member and the upper two in the Upper Callovian-Kimmeridgian part of the Lardyfjellet Member (Smelror et al., 2018). Due to limited exposure and strongly weathered surfaces, we have not defined any facies associations in this formation.

\section{Description}

The Oppdalen Member. The basal part consists of interbedded siltstone and massive red-coloured calcareous silt and sandstone or silty and sandy carbonates (Facies 5, Table 1). In Kükenthalfjellet, on Svenskøya, the member gradually passes upwards to a c. $20 \mathrm{~m}$-thick grey mudstone (Facies 2, Table 1) (Fig. 22). Plant fragments, common belemnites and poorly preserved ammonites, bivalves, and vertebrate remains are present throughout the member. Variations within the unit are mainly related to variable silt content, with decreasing silt upwards in the succession. Lack of stratification reflects a completely burrowed lithology. Centimetre- to decimetre-scale stratiform carbonate concretions, occasionally with numerous belemnites, are common together with decimetre-thick carbonate beds where siderite, dolomite and iron-rich calcite constitute the mineralogy.

The Lardyfjellet Member on Kong Karls Land is a black, organic-rich, shale unit (Fig. 23) (Facies 1, Table 1). There is a prominent colour change between the Oppdalen and the Lardyfjellet members. This unit on Kükenthalfjellet consists of a c. 12 m-thick, dark grey to black, organicrich paper shale, with common pyrite and thin silt laminae. As in the Oppdalen Member, centimetre to decimetre-scale carbonate concretions and continuous decimetre-thick carbonate beds are interbedded with the shale. Crushing of the claystone close to a volcanic sill or dyke gives a weak paraffinic odour.

\section{Interpretation}

The fine grain size, together with marine fossils and burrows, demonstrates that the Oppdalen Member was deposited in an outer shelf open marine environment. The change from the silty and greyish-coloured Oppdalen Member to the black, laminated, organicrich Lardyfjellet Member reflects a change from oxic 


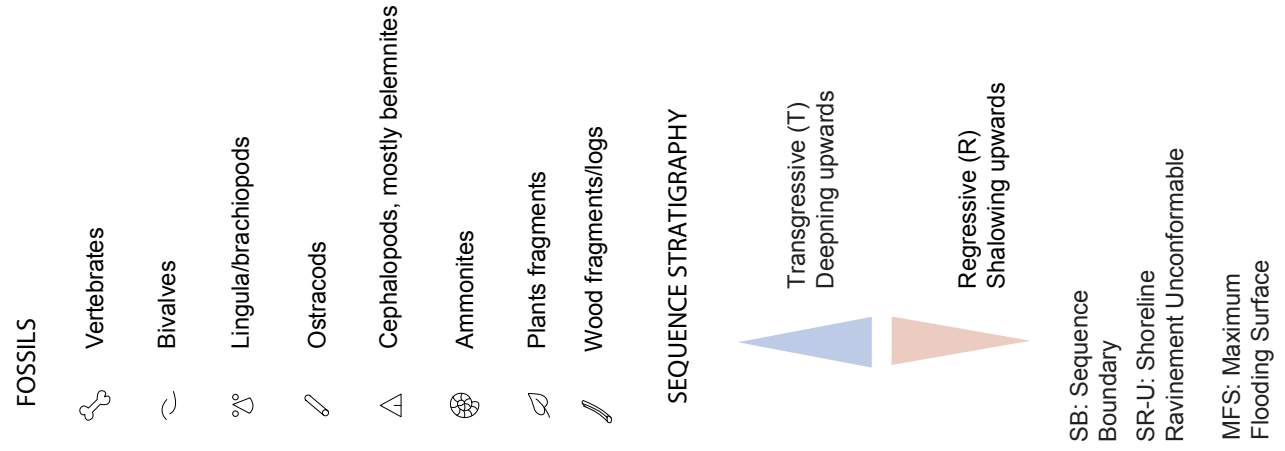
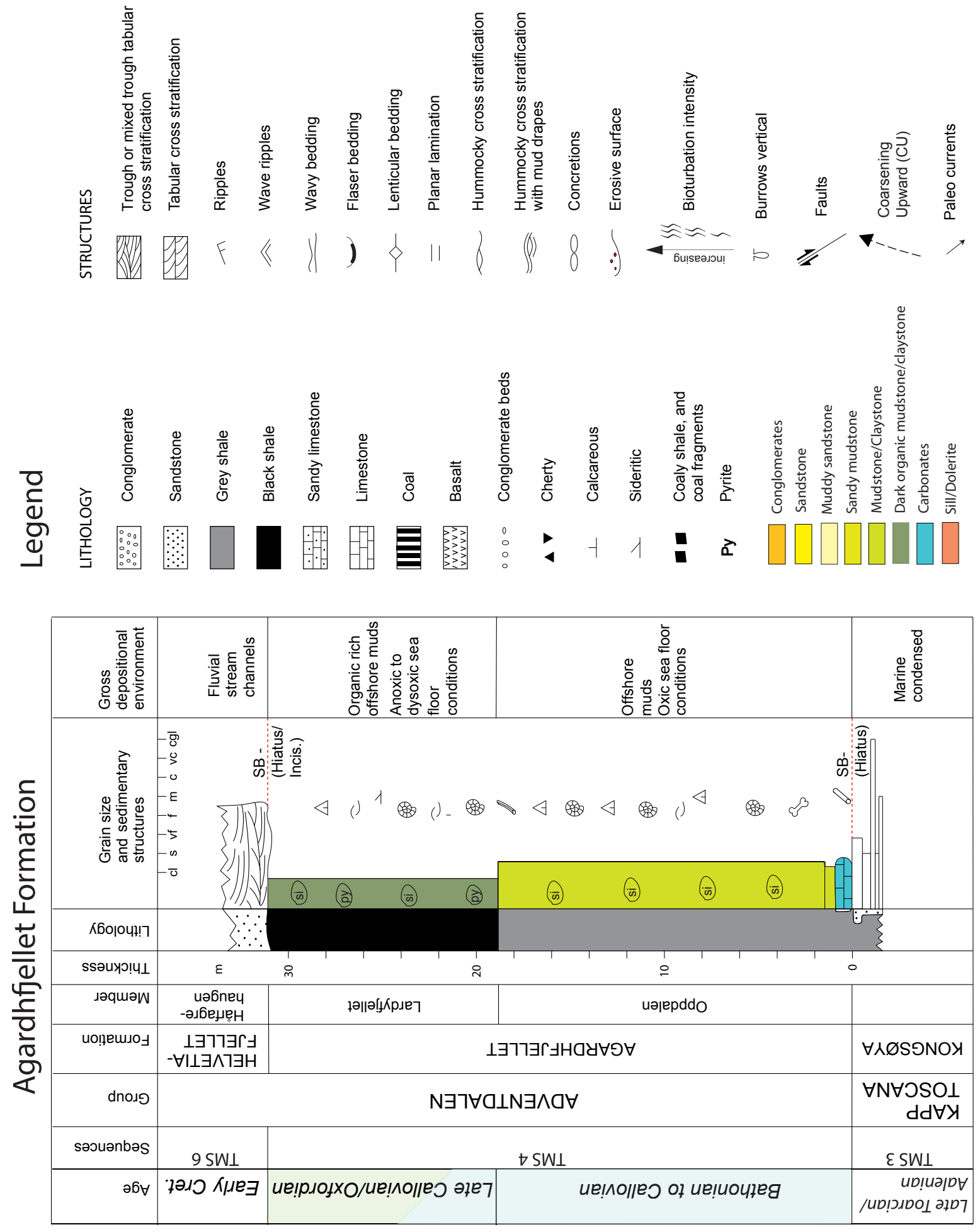
to dysoxic and anoxic bottom conditions. Sedimentary structures indicating storm waves are not observed, suggesting deposition below storm wave base. As on Spitsbergen, the change between more silty facies and carbonate beds with scattered burrows to black, fissile paper shales reflects periodic shifts between aerobic, dysaerobic and anaerobic water conditions (Dypvik et al., 1991a; Koevoets et al., 2016; 2018).

Continuous carbonate beds and beds with a high concentration of concretions probably represent previously fossiliferous beds or stratified lenses. Krajewski (2004) showed that carbonate beds in the Agardhfjellet Formation on Spitsbergen were formed by a combination of dissolution of biogenic carbonate and thermal decomposition of organic matter. Fossiliferous carbonate beds, including the belemnite beds within a predominantly siliciclastic mudstone, suggest condensation (Walker et al., 1983). The abrupt change from the silty Oppdalen to shaly Lardyfjellet Member (Figs. 22 \& 24) may have been caused by modifications in circulatory conditions in the basin and/ or by changes in relative sea level. The black organic-rich shale in the Lardyfjellet Member was deposited in a starved basin which, in periods, must have experienced increased organic production, probably including blooming of algae. The common occurrence of the freshwater algae Botryococcus in the Lardyfjellet Member (Smelror et al., 2018) indicates the occurrence of stratified water masses.

Summary of the depositional environment of the Agardhfjellet Formation

As on Spitsbergen, the Agardhfjellet Formation in Kong Karls Land was deposited on a marine shelf within an epicontinental sag basin with variable dysoxic, anoxic and oxic sea-floor conditions. (Dypvik et al., 1991b). Fig. 24 shows a correlation of the Agardhfjellet Formation between Svenskøya and Kongsøya.

The grey shale of the Oppdalen Member shows similarities to the Fuglen Member in the south-western Barents Sea.

Geochemical analyses of samples from the upper Lardyfjellet Member show that they have a significant potential for oil and gas generation. TOC values range from 6 to $30 \%$ and S2 values reach up to $106 \mathrm{~kg} \mathrm{KC/ton}$ rock. The Hydrogen index (HI) ranging from 106 to 355 suggests the kerogen to be type III/II to III. For more details, see below under the discussion of the maximal burial of the Messozoic succession.

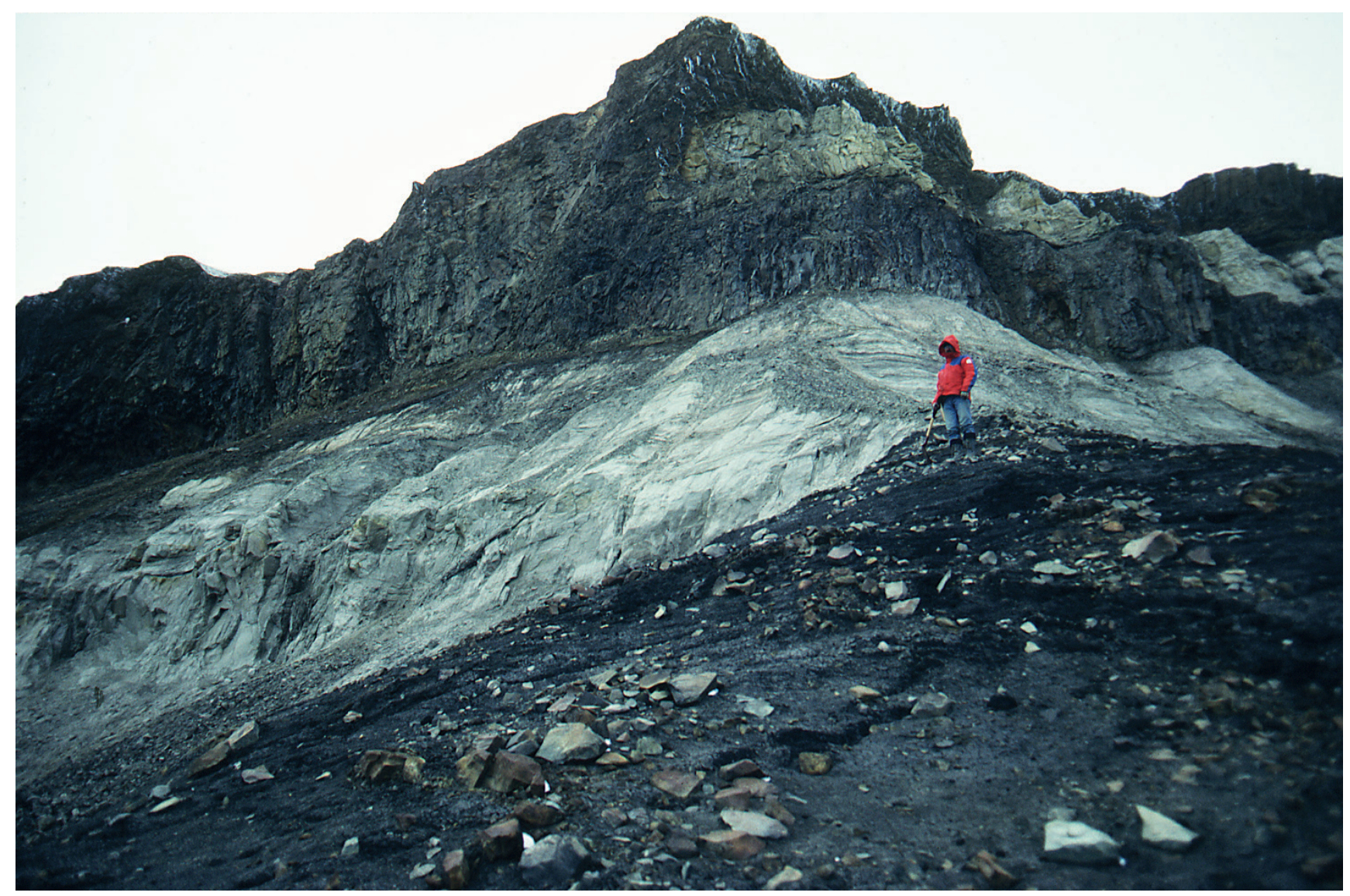

Figure 23. Black, organic-rich, paper shale of the Oxfordian to Kimmeridgian Lardyfjellet Member at Kükenthalfjellet overlain by white Barremian/Aptian fluvially deposited sandstone. The succession is capped by a subvolcanic sill of probably Aptian age which has intruded the Helvetiafjellet Formation. Note the sandstone bed trapped within the sill. 


\section{Svenskøya}

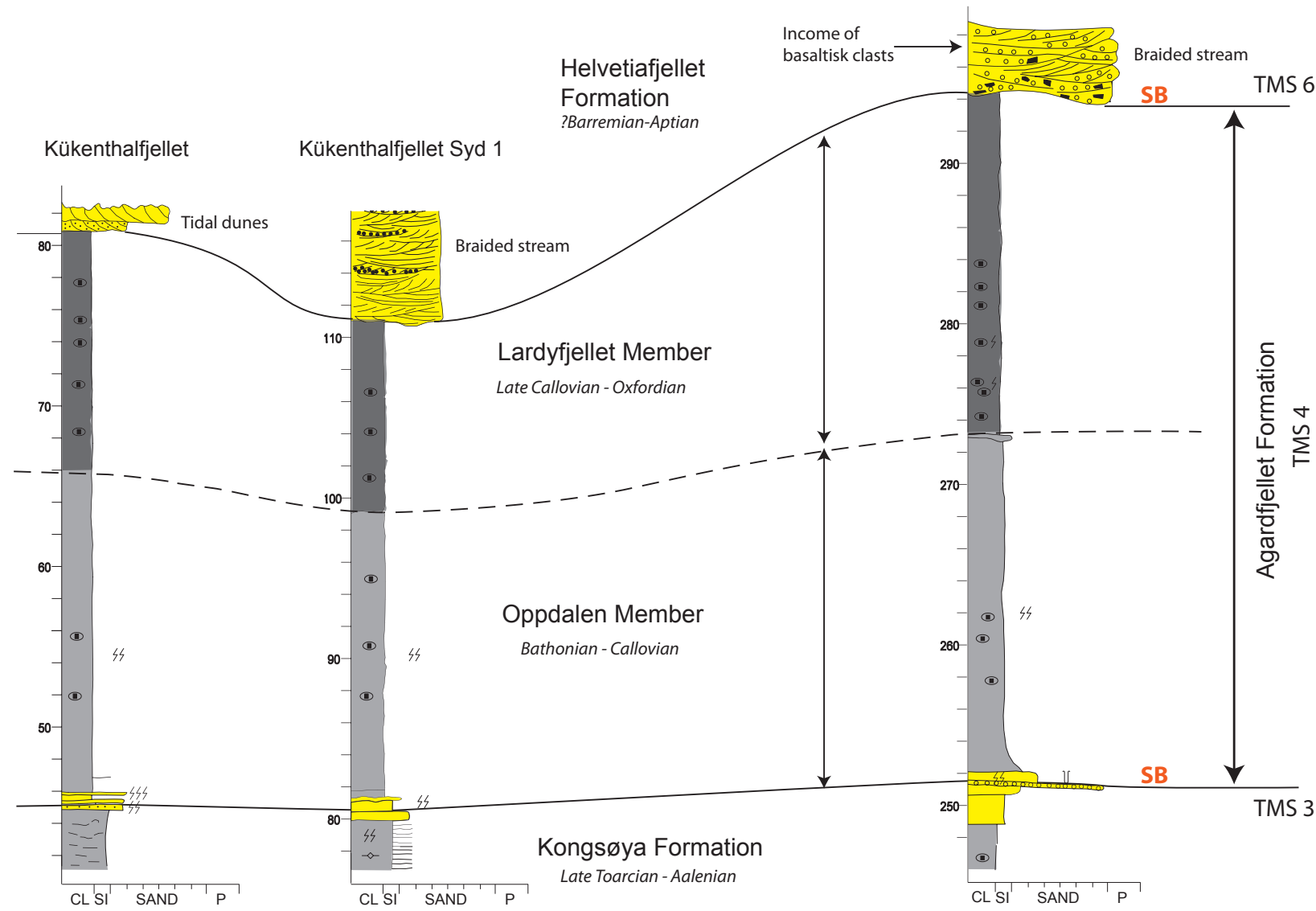

Figure 24. A correlation of the Agardhfjellet Formation between Svenskøya and Kongsøya. The thickness variation is partly due to structural lows and highs and incision by the overlying Helvetiafjellet Formation. Meter above sea level (MASL).

The Valanginian-Hauterivian Tordenskjoldberget Member (Klippfisk Formation) including the Kolje Formation

The approximately $30 \mathrm{~m}$-thick Tordenskjoldberget Member consists of a $15 \mathrm{~m}$-thick lower yellow and white calcareous sandstone to sandy limestone, described as "sand limestone" by Lindstrøm (1900), (here linked to facies 4 , Table 1) and an upper $15 \mathrm{~m}$-thick clay and siltstone unit with fragments of the bivalve (Inoceramus bed) lowermost and carbonate concretions higher in the succession (linked to facies 2, Table 1).

The type locality of the Tordenskjoldberget Member as reported by Smith et al. (1976) was not sampled for this study.

Smelror et al. (1998) revised the original definition of the member and assigned the upper clastic part to the offshore Kolje Formation. The reported thickness of the Tordenskjoldberget Member and the Kolje Formation may be slightly exaggerated due to relatively poor exposures and a structural dip in this area which is close to that of the topographic slope.

The Kutling Member of the Klippfisk Formation on IKU/NPD shallow core 7533/03-U-01 at the southern border of the Olga Basin is very fossiliferous, with Inoceramus fragments, the bivalve Buchia and belemnites (Fig. 25). This is the lateral offshore analogue of the Tordenskjoldberget Member. The Tordenskjoldberget Member and the shaly Kolje Formation are laterally correlative to the Valanginian-Hauterivian limestones and calcareous sandstones of the Klippfisk and the Kolje formations on the Barents Sea Shelf (Smelror et al., 1998; Mørk et al., 1999).

The fossiliferous Klippfisk Formation is interpreted as condensed offshore deposits (Smelror et al., 1998; Mørk et al., 1999). The description by Smith et al. (1976) also suggests a similar depositional environment for the Tordenskjoldberget Member. The Kolje Formation represents an offshore deposit (Smelror et al., 1998). 

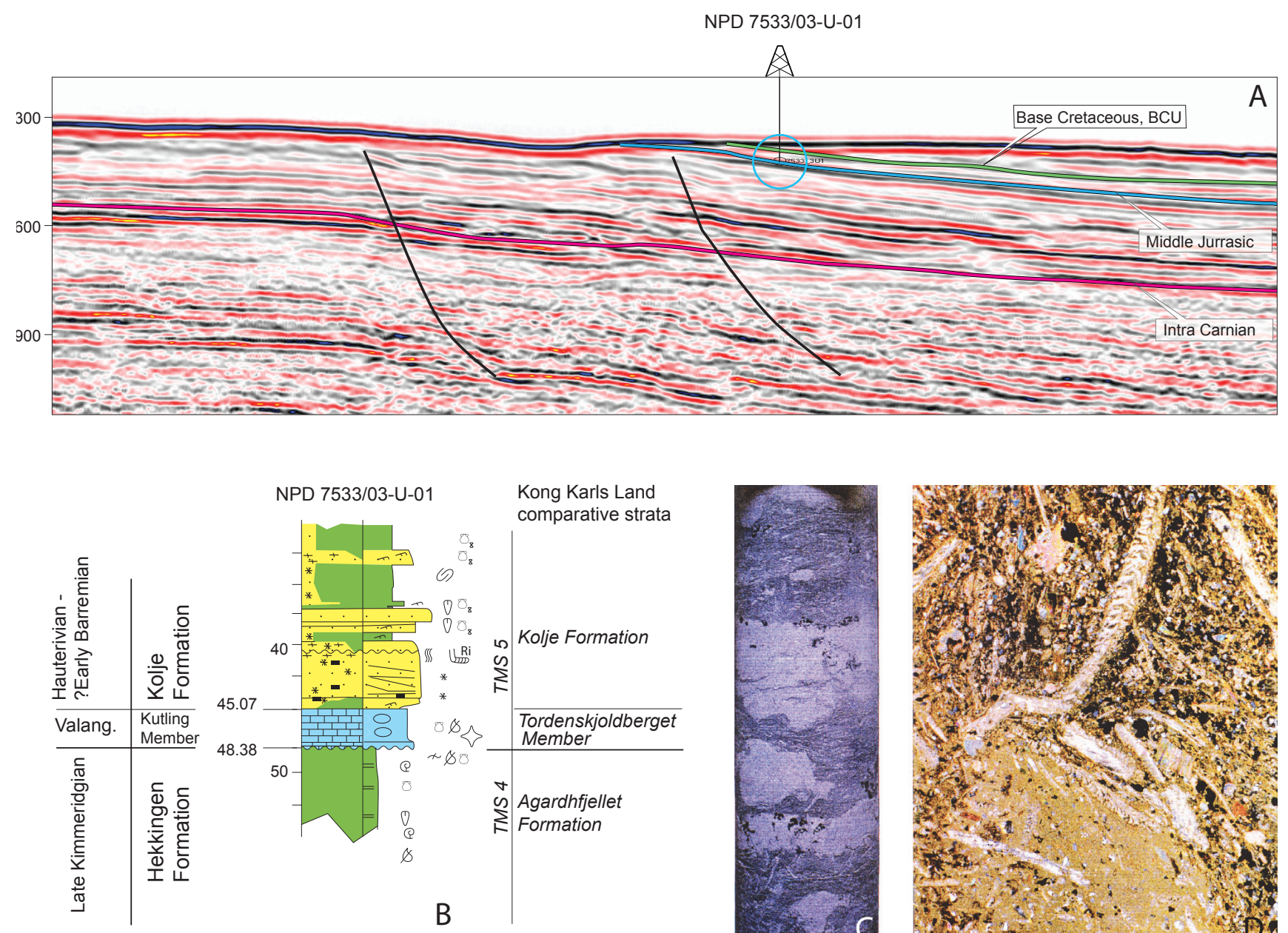

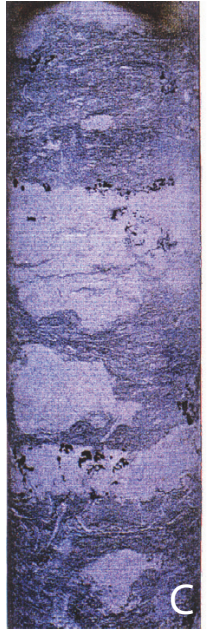

$0 \quad 2 \mathrm{~cm}$

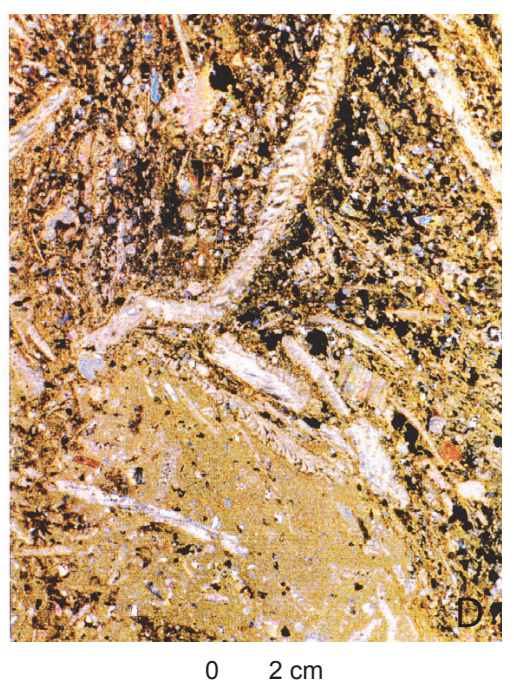

Figure 25. The offshore counterpart of the Tordenskjoldberget Member in Kong Karls Land. (A) Seismic line and well location see Fig. 1. (B) Cored section from shallow well NPD 7535/03-U-01. (C) Core and thin-section from the Kutling Member. (D) Inoceramus fragments in sandy limestone.

\section{Barremian-Aptian, Helvetiafjellet Formation}

The basin fill of Barremian to Early Aptian age comprises the youngest (uppermost) preserved rocks in Kong Karls Land. The Helvetiafjellet Formation consists of interfingering sedimentary rocks, the Hårfagrehaugen Member, and extrusive magmatic rocks, the Kong Karls Land flows (Mørk et al., 1999). We note that in some localities it is difficult to distinguish between the shallowly emplaced intrusive and the extrusive magmatic rocks. The preserved thickness of the Helvetiafjellet Formation varies from 10 to c. $60 \mathrm{~m}$. The Hårfagrehaugen Member consists of sandstone, volcanoclastics, conglomerates and shale with subordinate coal and coaly shale. Plant fragments and tree trunks are common throughout the member. On Kongsøya there is an abrupt change from quartz arenites to immature sandstones (i.e., feldspar rich and volcanoclastics) within the member (Fig. 26).

The sedimentary succession of the Helvetiafjellet Formation comprises three facies associations. HFA-1 \&
2 constitute the Hårfagrehaugen Member while HFA-3 belongs to the Kong Karl Land flows and consists of volcanic extrusive rocks.

\section{Facies association HFA-1, fluvial channels Description}

This facies association varies from 4 to $20 \mathrm{~m}$ in thickness and is organised in sharp to clearly erosive-based FU units (Figs. 26 \& 27A). At most localities HFA-1 clearly erodes the uppermost Agardhfjellet Formation with a measurable erosional relief up to $10 \mathrm{~m}$ (Figs. $4 \& 27 \mathrm{~A})$. On Svenskøya and in the lower part of the Hårfagrehaugen Member on Kongsøya, the association consists of white to light greyish, fine- to coarsegrained, subarkosic to quarzitic arenites. Unidirectional SW-directed 2D and 3D dunes (Facies 13 and 14, Table 1) organised in larger cut-and-fill structures are the most common sedimentary structures. Moderately to well sorted, fine to very fine-grained $0.2-2 \mathrm{~m}$-thick, current ripple laminated sandstones (Facies 12, Table 1) cap the upper parts of the FU units and in places intersect the 
dunes. Scattered soft-sediment deformation structures are also observed. In the lower part of the member at Kükenthalfjellet and at Sjøgrenfjellet, double mud drapes are observed on tabular strata (Fig. 27B, C). There is also a decreasing grain-size trend from north to south on Svenskøya.
On Kongsøya, the middle part of the basal sandstone bed shows an abrupt colour and grain size change from whitish medium-grained sandstone to greenish, poorer sorted, coarse to very coarse-grained sandstone, with thin beds and lenses of polymictic conglomerates with well-rounded gravel and pebble sized basalt clasts. This

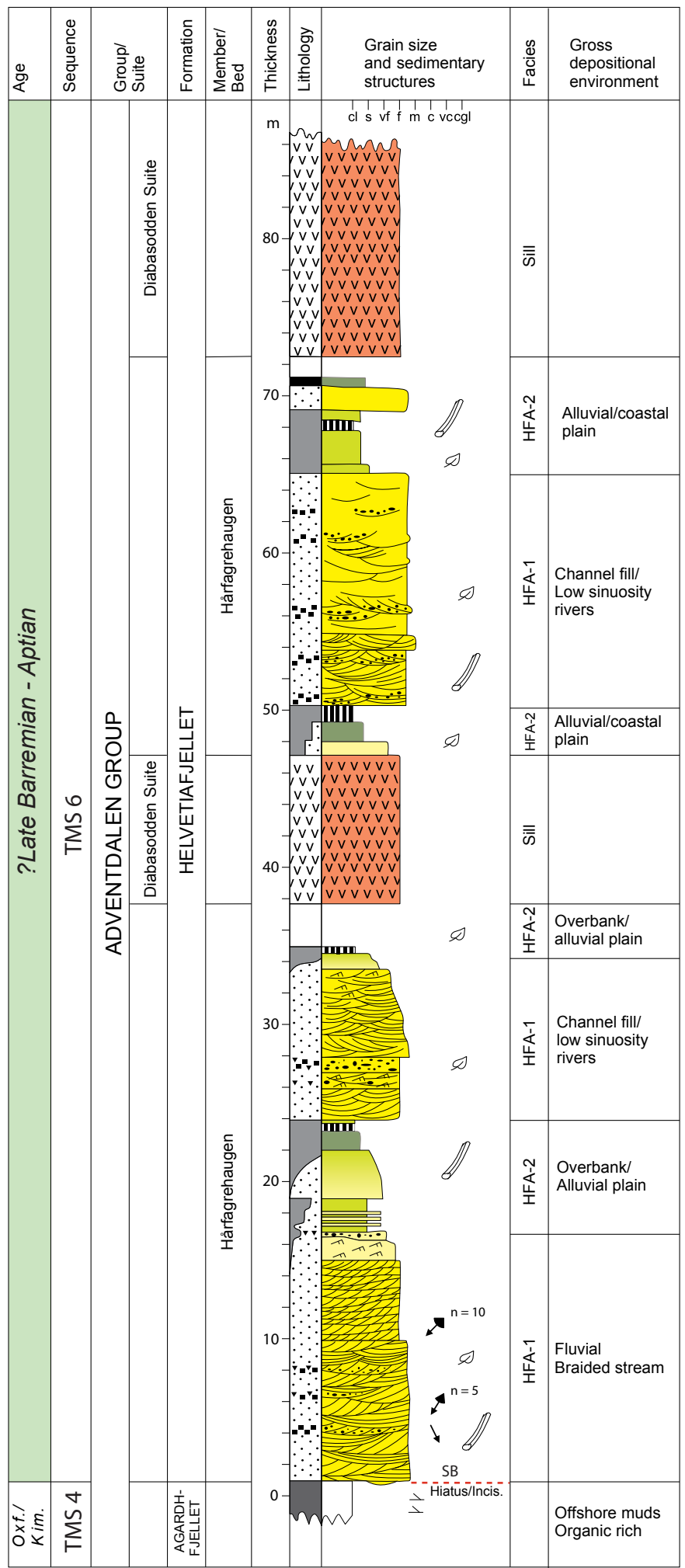

Figure 26. Log from the Helvetiafjellet Formation, southern Kükenthalfjellet, Svenskøya. For legend see Figure 22. 


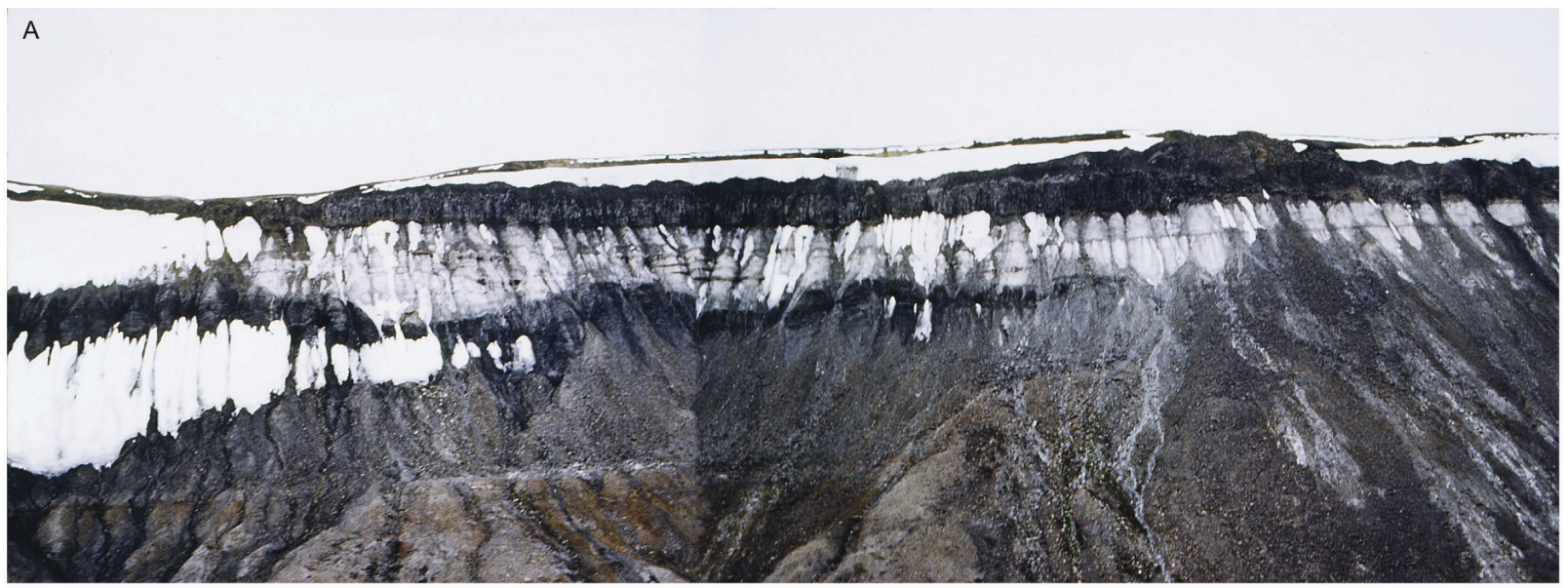

\section{KÜKENTHALFJELLET}

S section
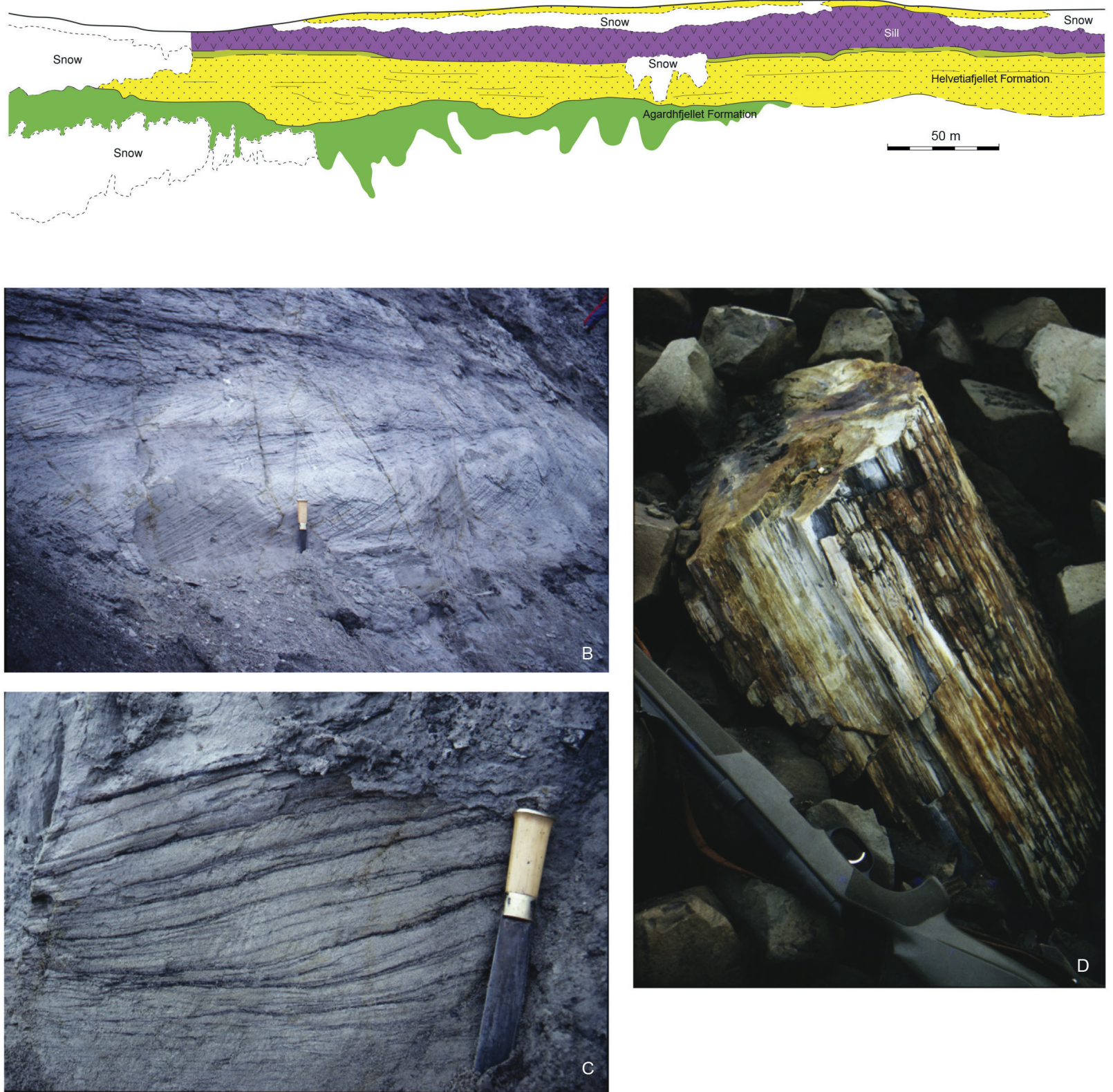

Figure 27. Helvetiafjellet Formation. (A) Erosional surface (incision) of the Hårfagrehaugen Member onto Agardhfjellet Formation, yellow fluvial sandstone, light green - overbank. South face of Kükenthalfjellet, Svenskøya. (B) Tidal dunes at the base of the Hårfagrehaugen Member, HFA-1. (C) Flaser bedding in the lower part is capped by tabular bedding with double drapes. (D) Silicified trunk from HFA-2, a common feature in this $F A$. 
part of the basal sandstone bed is rich in smectite and dominated by plagioclase with minor quartz grains and is classified as sub-arkosic to arkosic arenites.

\section{Interpretation}

The complex organisation, with vertical variations in grain size and poor sorting usually composed of several fining-upward units associated with in situ coal and root horizons in HFA-2 below suggests a fluvial origin for HFA-1. The $2 \mathrm{D}$ and $3 \mathrm{D}$ dunes are interpreted as representing migrating longitudinal and transverse bars within a fluvial channel complex (cf., Allen, 1983). The up to $20 \mathrm{~m}$-thick sub-tabular benches with apparently sharp erosive bases indicate deposition in shallow, laterally extensive channel belts and sand flats on a larger alluvial braid plain. Occurrences of double drapes in the base of the member at some localities indicate a tidal influence. These are interpreted as remains of tidal deposits later eroded by fluvial channels. Tidal features are also commonly observed in lower parts of the Helvetiafjellet Formation in Spitsbergen (Gjelberg \& Steel, 1995; Midtkandal \& Nystuen, 2009).

The sub-arkosic to arkosic arenites with basalt pebbles, i.e., volcanoclastics, were probably derived from extrusive basalts belonging to the Kong Karls Land Flows deposited on the watershed supplying sediment to the Helvetiafjellet Formation. Sub-regionally, at least within the Kong Karls Land archipelago, the colour change and volcanoclastic influx is interpreted to represent a chronostratigraphic event.

Facies association HFA-2, coastal/alluvial plain fines Description

Poorly to moderately sorted 2-4 m-thick units of light/ dark grey claystone and siltstone, with laminae and thin beds of sandstone (Facies 11,12, Table 1) in alternation with up to $1 \mathrm{~m}$-thick in situ coals with rootlets are the main constituents of this facies association on Svenskøya (Facies 12, 15, Table 1). Plant fragments are common. A kaolinitic claystone bed (Facies 16, Table 1) is usually observed below coal or coaly shale (Facies 15, Table 1). The coal beds are better developed and generally thicker on Svenskøya than on Kongsøya. A 0.5-3 m-thick, light grey, fine to very fine-grained sandstone with scattered ripple lamination (Facies 12, Table 1) with an upwardsfining or blocky motif is observed at a few localities. Well laminated, varve-like, mudstone occurs in the upper part of the Hårfagrehaugen Member and is the dominating facies between units of magmatic rocks on Kongsøya. The sandstones generally interfinger with mudstone and coal. Silicified wood from tree trunks, logs and branches are common (Fig. 27D).

\section{Interpretation}

The combination of claystone and siltstone with roots and coal indicates deposition on floodplains lateral to the channel units of HFA-1. The spore flora suggests well ventilated conditions and mainly well-drained flood plains (Smelror et al., 2018). The sandstones probably represent flood episodes with deposition of sand beyond the channel belts as widespread overbank flooding and crevasse splay sands. Clays and sands with root structures and kaolinites below coal horizons represent periods with soil profile generation and no active sedimentation. The kaolinite beds below the coals are interpreted as seat earths, which are normally associated with a warm or seasonally warm climate (Sheldon \& Tabor, 2009). Common seat earths are reported in the Lower Cretaceous succession on Spitsbergen (Nemec, 1992). The uppermost laminated (varved) mudstone in the Hårfagrehaugen Member suggests deposition in a standing body of water probably in a lake on an alluvial plain.

Facies association HFA-3, volcanic extrusive rocks (Kong Karls Land Flows)

Extrusive and hypabyssal (sills and dykes) intrusive basaltic rocks cap the sedimentary sequences in Kong Karls Land. Given the fine-grained nature of both intrusive dolerites and extrusive basalts and the poorly preserved upper contacts of the units in many places, it is not always clear in the field if they represent extrusive rocks or very shallow sill intrusions. On Svenskøya, intrusions are interpreted due to their cross-cutting relationships between the basaltic rocks and the Helvetiafjellet Formation. This implies a shallow level of emplacement, although the top of the pre-volcanic Helvetiafjellet Formation is not preserved on the island. Examples of interpreted lava flows are two layers of basalts at Hårfagrehaugen (Fig. 4). The basalts reveal massive and columnar jointed basalts organised in lobes (Fig. 28).

The upper surface of the lower basalt has a scoriaceous reddish to greenish surface overlain by an up to $7 \mathrm{~m}$-thick volcanic scoria breccia, probably a pyroclastic and autobrecciated blocky lava top (Fig. 29). This volcanic breccia is followed by a thin bed of volcanoclastic sandstone and an up to $5 \mathrm{~m}$-thick consolidated greyish/greenish tuff with big lava fragments and pumice. This succession is overlain by sandstone which passes up to black mudstone of facies association HFA-2 towards the southeast.

At Retziusfjellet, Tordenskjoldberget and Sjøgrenfjellet on Kongsøya, the two layers of basalt are less well defined. They are intercalated with dark grey shales belonging to HFA-2 in the upper part of the Helvetiafjellet Formation. While the thickness of the lower basaltic layer varies from a few metres to about $40 \mathrm{~m}$, the uppermost layer was measured as up to $\mathrm{c} 20 \mathrm{~m}$ thick. Its maximum thickness is unclear because of its eroded top surface. The rocks here are also massive and include columnar jointed basalts. It is unclear if these are lavas or sills.

Basalts cap the sedimentary succession on Svenskøya, including the upper part of the Helvetiafjellet Formation. Upper parts of the basalt seem to have been partly removed by glacial erosion. Also a basaltic layer here 


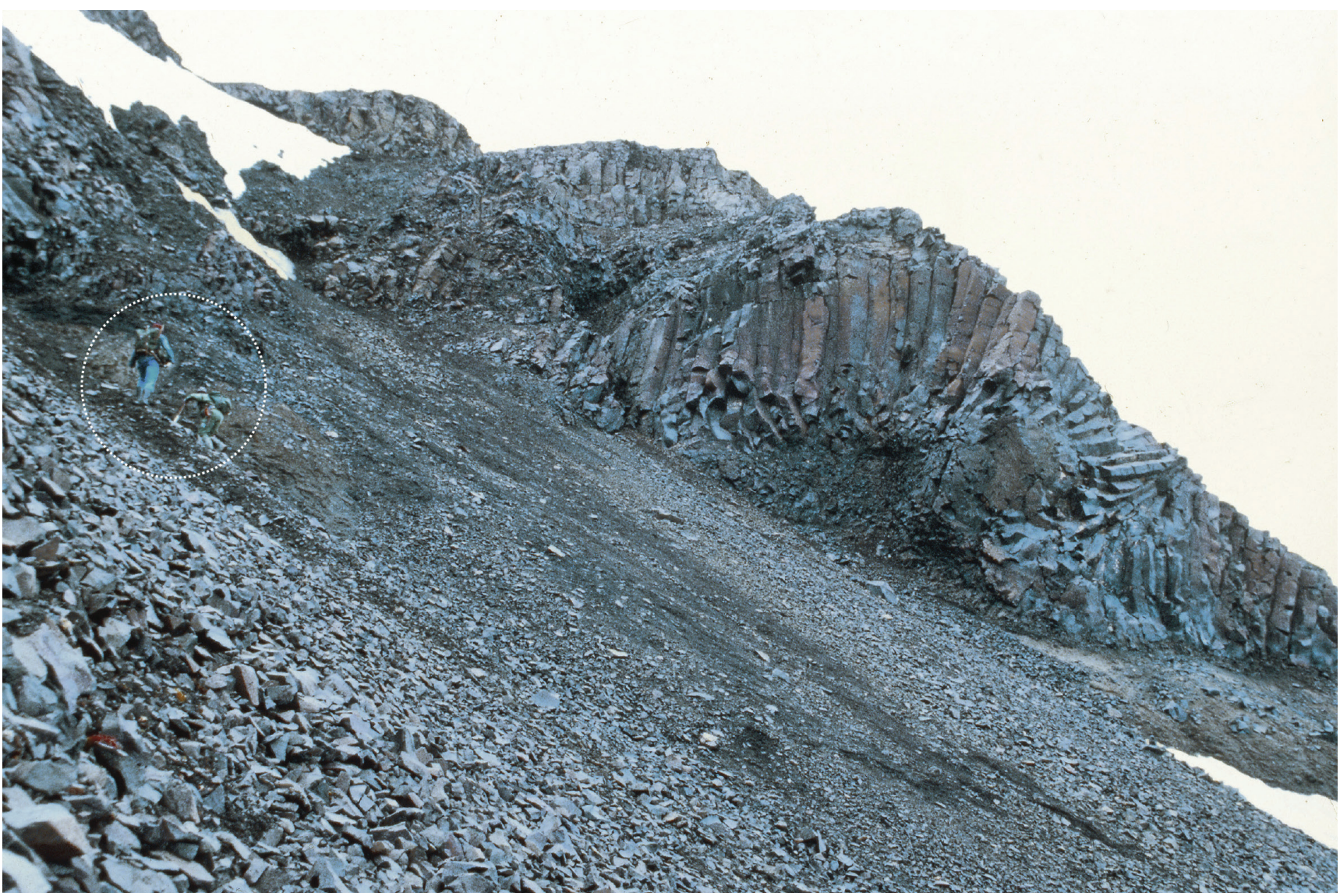

Figure 28. Two-tiered columnar jointing in flood basalts in Kong Karls Land Flows resting on fluvial sandstones, HFA-1, of the Hårfagrehaugen Member, Hårfagrehaugen, Kongsøya. Geologists for scale, encircled.

is intercalated between white subarkosic sandstones of the Helvetiafjellet Formation with no evidence of volcanoclastics or weathered basalt surfaces. This is consistent with the interpretation that no lavas, only sills are seen on Svenskøya (Grogan et al., 2000).

The lavas are part of a Lower Cretaceous basin fill in Kong Karls Land. Published studies on both extrusive and intrusive igneous rocks are mainly based on the analysis of samples taken from old expeditions as reported by Bailey \& Rasmussen (1997). In addition, new samples were collected during the fieldwork for this study and analyses were partly published in Grogan et al. (2000).

Two major intrusion centres on Svalbard were proposed by Nejbert et al. (2011): a central Spitsbergen dolerite

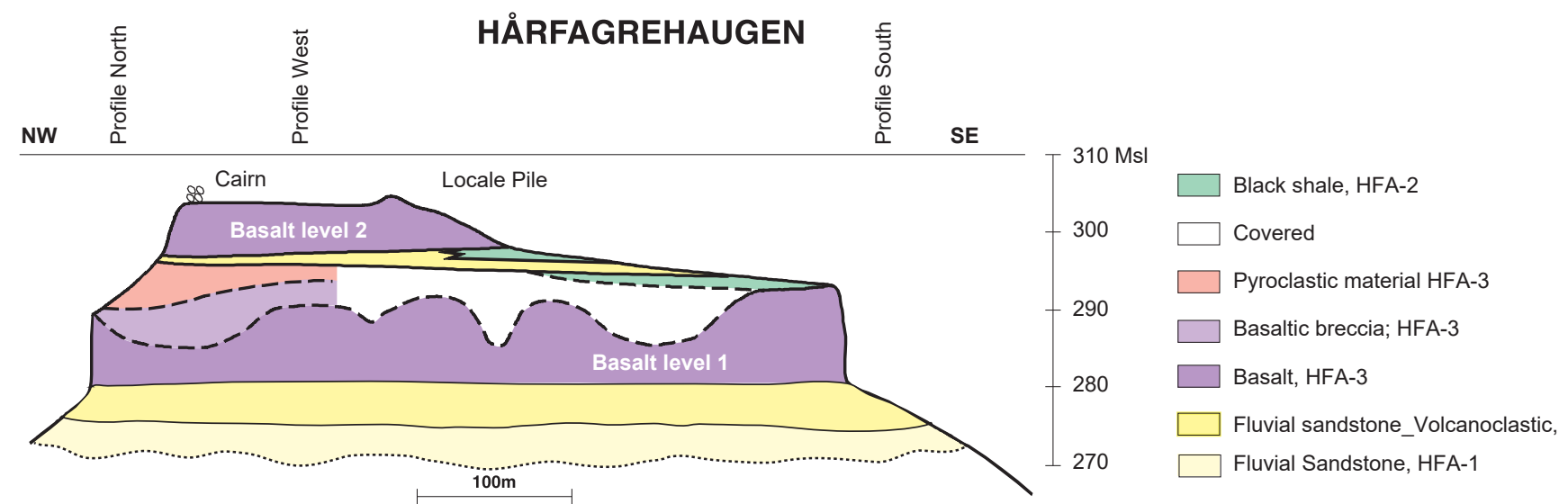

Figure 29. Cross-section of the volcanic rocks at Hårfagrehaugen, Kongsøya. 
centre and an eastern Svalbard dolerite belt, which includes the Kong Karls Land lava flows and the shallowly emplaced sills and dykes. The composition of the igneous rocks in Kong Karls Land is consistent with all Lower Cretaceous igneous rocks on Svalbard (Senger et al., 2014a). Bailey \& Rasmussen (1997) classified the basaltic rocks as typical plateau flood basalts of medium $\mathrm{TiO}_{2}$ tholeiitic types. Igneous rock fragments are also observed in the Helvetiafjellet Formation on Spitsbergen (Edwards, 1979; Maher, 2001). Bentonites recently discovered in the middle part of the Helvetiafjellet Formation in the central part of Spitsbergen (Corfu et al., 2013) are dated to Early Aptian, suggesting they are coeval with timing of the eruption in Kong Karls Land (Senger et al., 2014a; Polteau et al., 2015).

Summary of the depositional environment of the Helvetiafjellet Formation

Fig. 30A shows the correlation of the Helvetiafjellet Formation. The erosive base of the formation cuts down up to tens of metres into the offshore deposited Agardhfjellet Formation (Figs. 27A \& 30A). The lower part of the formation on Kong Karls Land is interpreted as representing braided fluvial channel fills following the axial parts of synclines (Fig. 30B, C). The tidally deposited sandstones in the basal part of the formation (Fig. 27B, C) proabably represent remains of tidal deposits. The formation is interpreted as an incised valley fill. The coastline is speculated to have not been far from Kong Karls Land (Fig. 30B).

\section{Tectonics and sequence stratigraphy of the Norian to Aptian basin fill in Kong Karls Land and nearby offshore areas}

\author{
Combined with data from nearby offshore seismic we \\ have identified six tectonic stages in the Norian to Aptian \\ succession in Kong Karls Land.
}

The present-day structural setting is controlled by major fold structures (Figs. 2 \& 31). The folds were initiated in the Late Jurassic (stage 4) and later rejuvenated in the Early Cretaceous (stage 5) and further compressed in a tectonic phase which is likely to be Palaeogene, but can only be dated with certainty to younger than Aptian due to erosion of younger strata (Grogan et al., 1999, 2000).
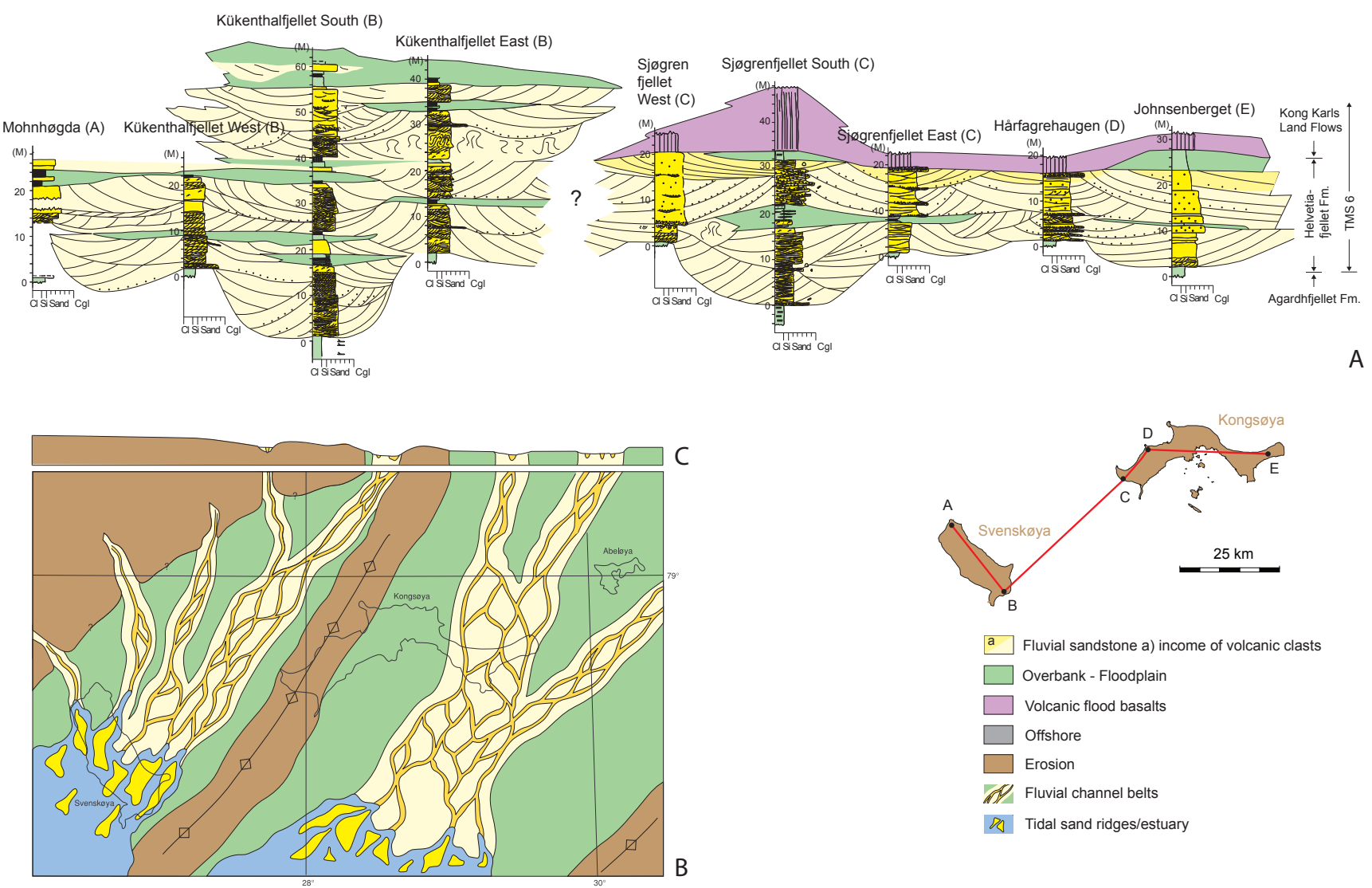

Figure 30. Helvetiafjellet Formation. (A) Log correlation of the Hårfagrehaugen Member and Kong Karls Land Flows (lava in pink). Sills are removed from this correlation as they are not regarded as a basin fill, but they probably influenced the topography as they are shallow intrusions. Note bright yellow sandstones in upper part of Kongsøya which show the sudden influx of volcanoclastic fluvial sandstone conglomerates. (B) Conceptual palaeogeographic map of the Helvetiafjellet Formation, the drainage pattern following the axes of the synclines. (C) A cross-section of the reconstructed topography. 


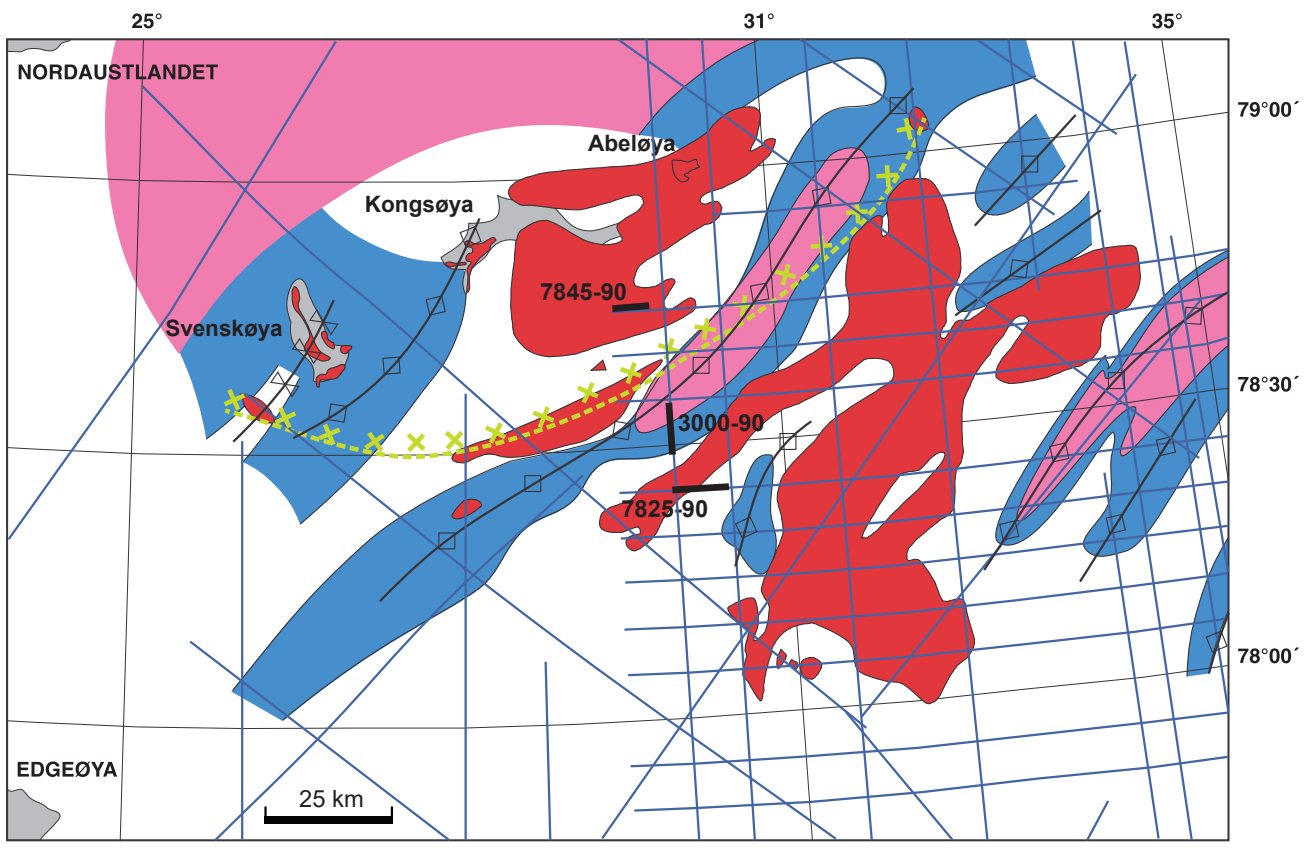

Islands

Basalts, extrusives on Kongsøya

Subcrop of Seismic

Unit A+B towards seafloor

Subcrop of pre Seismic Unit A

Possible southern limit of basalt, Lower Cretaceous level

$\varnothing$ Anticlinal trend

4 synclinal trend

Seismic sections as shown on figures 5 and 6

_ Seismic lines used in interpretation

Figure 31. Structural map of Kong Karls Land and nearby offshore areas.

The informal subdivision of the six tectonic stages is observed throughout the northeastern Barents Sea and partly on Svalbard. Some of these stages were also suggested by previous studies (e.g., Steel \& Worsley, 1984; Harland, 1997; Grogan et al., 1999, 2000; Worsley, 2008; Smelror et al., 2009; Klausen et al., 2015), consistent with our stage 2, while Kairanov et al. (2018) concur with our stages 5 and 6 . As will be discussed below, the timing of the contraction tectonics in stages 4 and 5 corresponds to phases with extension in the North Atlantic and southwestern Barents Sea and the rifting related to the 'mid Cretaceous' rift in the Amerasian Basin (Embry, 2011).

These tectonic stages provide further background for the definition of six tectonic megasequences (TMSs) in Kong Karls Land as shown in Fig. 3. The TMSs are bounded by key sequence-stratigraphic surfaces as summarised in Table 2 and Fig. 32. We have constructed paleogeographic maps (Fig. 33) for some selected periods, well aware of great uncertainties due to Late Mesozoic and younger erosional events, particularly in the north and northeast.

Sequence-stratigraphic surfaces such as subaerial unconformities, ravinement surfaces and flooding or transgressive surfaces to a large extent follow the upper and lower boundaries of the Mesozoic lithostratigraphic units (e.g., members, formations, subgroups and groups) in Kong Karls Land, throughout most of the Svalbard Archipelago, and to some extent the Barents Sea Platform. Including the time-equivalent strata on Hopen and the offshore Klippfisk Formation, we have defined seven key sequence-stratigraphic boundary surfaces for the Mesozoic succession in Kong Karls Land which also largely coincide with the bases of the lithostratigraphic units. These are annotated SB (sequence boundary) on the stratigraphic logs presented in the previous chapter and are summarised in Table 2 and in Figs. 3 \& 32. Of the seven surfaces identified, six $(1,2,4,5,6$ and 7$)$ are regionally significant and define the bases of the TMS sequences (cf., Table 2) that are recognised in outcrops and/or immediately offshore Kong Karls Land. Together with the base of TMS 1, these six boundary surfaces are also recognised in correlative seismic reflectors in the northern Barents Sea. In contrast to the two lower tectonic megasequences TMS 1 and 2, the upper four sequences of TMS 3, 4, 5, and 6 are only seen either as erosional remains or as condensed facies in Kong Karls Land and on the Kong Karls Land Platform.

Below, we discuss the tectonic and sequence stratigraphy of the six megasequences.

\section{The Norian to Aalenian tectonic megasequences TMS 1, 2 and 3}

No tectonic tilting, faulting or angular unconformities have been observed in Kong Karls Land and the adjacent northern Barents Sea for the tectonic stages 1, 2 and 3, which both onshore and in immediately offshore strata span a latest Permian to Aalenian age. As Bajocian deposits are missing in Svalbard and on nearby platforms (Smelror et al., 1998, 2018), this stage is represented by a hiatus and by observed Bathonian flooding. Elsewhere in the Barents Sea, the upper boundary of TMS 3 is 
Table 2. Key sequence-stratigraphic surfaces identified in Kong Karls Land and on the Kong Karls Land Platform. (1 is based on seismic, 2 and 3 based on outcrops at Hopen).

\begin{tabular}{|c|c|c|c|c|c|}
\hline No & $\begin{array}{c}\text { Age of surface below/ } \\
\text { above }\end{array}$ & $\begin{array}{l}\text { Type of sequence } \\
\text { stratigraphic surface }\end{array}$ & $\begin{array}{c}\text { Corresponding boundary } \\
\text { of lithostratigraphic unit } \\
\text { Kong Karls Land }\end{array}$ & $\begin{array}{l}\text { Base of seis- } \\
\quad \text { mic unit }\end{array}$ & $\begin{array}{c}\text { Correlative lower boundary } \\
\text { of lithostratigraphic unit off- } \\
\text { shore SW Barents Sea }\end{array}$ \\
\hline 8 & $\begin{array}{c}\text { Hauterivian/ } \\
\text { ?Barremian-?Aptian }\end{array}$ & Subaerial unconformity & $\begin{array}{l}\text { Base Helvetiafjellet } \\
\text { Formation }\end{array}$ & $\mathrm{F}$ & Not applicable \\
\hline 7 & $\begin{array}{l}\text { Late Kimmeridgian/ } \\
\text { Valanginian }\end{array}$ & $\begin{array}{l}\text { Probable subaerial } \\
\text { unconformity }\end{array}$ & $\begin{array}{l}\text { Base Tordenskjoldberget } \\
\text { Member }\end{array}$ & & $\begin{array}{l}\text { Base Klippfisk, Knurr or Kolje } \\
\text { formations (BCU) }\end{array}$ \\
\hline 6 & $\begin{array}{l}\text { Early Aalenian/ } \\
\text { Late Bathonian }\end{array}$ & Subaerial unconformity & Base Agardhfjellet Formation & $\mathrm{E}$ & $\begin{array}{l}\text { Top Realgrunnen Subgroup or } \\
\text { top Kapp Toscana Group or base } \\
\text { Fuglen Formation }\end{array}$ \\
\hline 5 & $\begin{array}{l}\text { Early Toarcian/ } \\
\text { Late Toarcian }\end{array}$ & $\begin{array}{l}\text { Combined subaerial } \\
\text { unconformity and wave } \\
\text { ravinement surface }\end{array}$ & Base Kongsøya Formation & $\mathrm{D}$ & $\begin{array}{l}\text { Probably base } \\
\text { upper Stø Formation }\end{array}$ \\
\hline 3 & $\begin{array}{l}\text { Late Norian-Early Rhaetian/ } \\
\text { Late Norian Early Rhaetian }\end{array}$ & Subaerial unconformity & $\begin{array}{l}\text { Base Svenskøya Formation, } \\
\text { identified on Hopen, not } \\
\text { exposed in Kong Karls Land }\end{array}$ & B & Base Tubåen Formation \\
\hline 2 & $\begin{array}{l}\text { Early Norian/ } \\
\text { Early Norian }\end{array}$ & Wave ravinement surface & $\begin{array}{l}\text { Base Flatsalen Formation, } \\
\text { identified on Hopen, not } \\
\text { exposed in Kong Karls Land }\end{array}$ & A & $\begin{array}{l}\text { Base Fruholmen Formation or } \\
\text { base Realgrunnen Subgroup }\end{array}$ \\
\hline 1 & $\begin{array}{l}\text { Late Changhsingian/ } \\
\text { Late Changhsingian }\end{array}$ & $\begin{array}{l}\text { Strong seismic reflector, } \\
\text { probably combined omission } \\
\text { and flooding surfaces }\end{array}$ & $\begin{array}{l}\text { Observed on seismic lines } \\
\text { immediately offshore Kong } \\
\text { Karls Land }\end{array}$ & & Top Tempelfjorden Group \\
\hline
\end{tabular}

correlated to the lower sequence boundary of the Upper Bajocian to Hauterivian megasequence in East Greenland (Surlyk, 2003).

\section{TMS 1. Late Changhsingian-Late Norian/Early} Rhaetian

TMS 1 was deposited as a response to the denudation of the Uralian mountain chain and the Fennoscandian Shield in the southeast (Petrov et al., 2008a, b; Klausen et al., 2015). A contemporary thick sag basin developed in the eastern Barents Sea. The eastern part of Svalbard and nearby platform was filled by northwest-prograding paralic sediments, deltas, shoreline and shelf-edge deltas (Riis et al., 2008; Glørstad-Clark et al., 2010; Нøy \& Lundschien, 2011; Anell et al., 2014a, b; Klausen et al., 2017a). The basin fill of TMS 1 is observed on nearby offshore seismic (Fig. 6). The lower sequence boundary of TMS 1 is probably Late Changhsingian in age i.e., near top Permian, i.e., top Kapp Starostin Formation on Svalbard and equivalent to the near top Permian reflector in the Barents Sea, i.e., top Tempelfjorden Group (Fig. 6.). The upper boundary is near the Norian-Rhaetian transition and is defined at the base of the Svenskøya Formation on Svalbard and at the base of the Tubåen Formation offshore. Only the uppermost part of TMS 1 is observed in Kong Karls Land, in the Norian Flatsalen Formation.
Sequence stratigraphy of the Flatsalen Formation During the Early Norian Pan-Arctic Transgression (Johannessen \& Embry, 1989; Embry, 1997; Mørk \& Smelror, 2001) sediment input from the east gradually became restricted and confined to the subsiding South Barents Sea Basin, which acted as a sedimentary sink (Klausen et al., 2016). Additionally, subsidence in basins on parts of the Barents Shelf, including Svalbard, was slowing down, and the Svalbard platform become a structural high with less accommodation space (Henriksen et al., 2011; Anell et al., 2014, 2016; Ryseth, 2014; Vigran et al., 2014). The influence of this limited accommodation is reflected by the thin time-equivalent successions of c $60 \mathrm{~m}$ on Hopen, (Lord et al., 2014) and between 3-20 m in west and central Spitsbergen (Rismyhr et al., 2019) (Fig. 32). On Kong Karls Land, combined with nearby offshore seismic, we suggest a $\mathrm{c}$. $100 \mathrm{~m}$ (Fig. 7) succession, which can be interpreted as a transgressive-regressive sequence. The lower sequence boundary is defined at the base of the Slottet Bed, (key sequence-stratigraphic surface 2) (Figs. $8 \& 9$, Table 2) which is correlative throughout Svalbard (Mørk et al., 1999). In the southwestern Barents Sea, the Slottet Bed is correlative to the base of the Realgrunnen Subgroup (Johannessen \& Embry, 1989; Henriksen et al., 2011) often informally referred to the top Snadd, Base Fruholmen or lower Norian seismic reflector. The regional occurrence of this event reflects a large-scale sea-level rise that established a seaway between the 


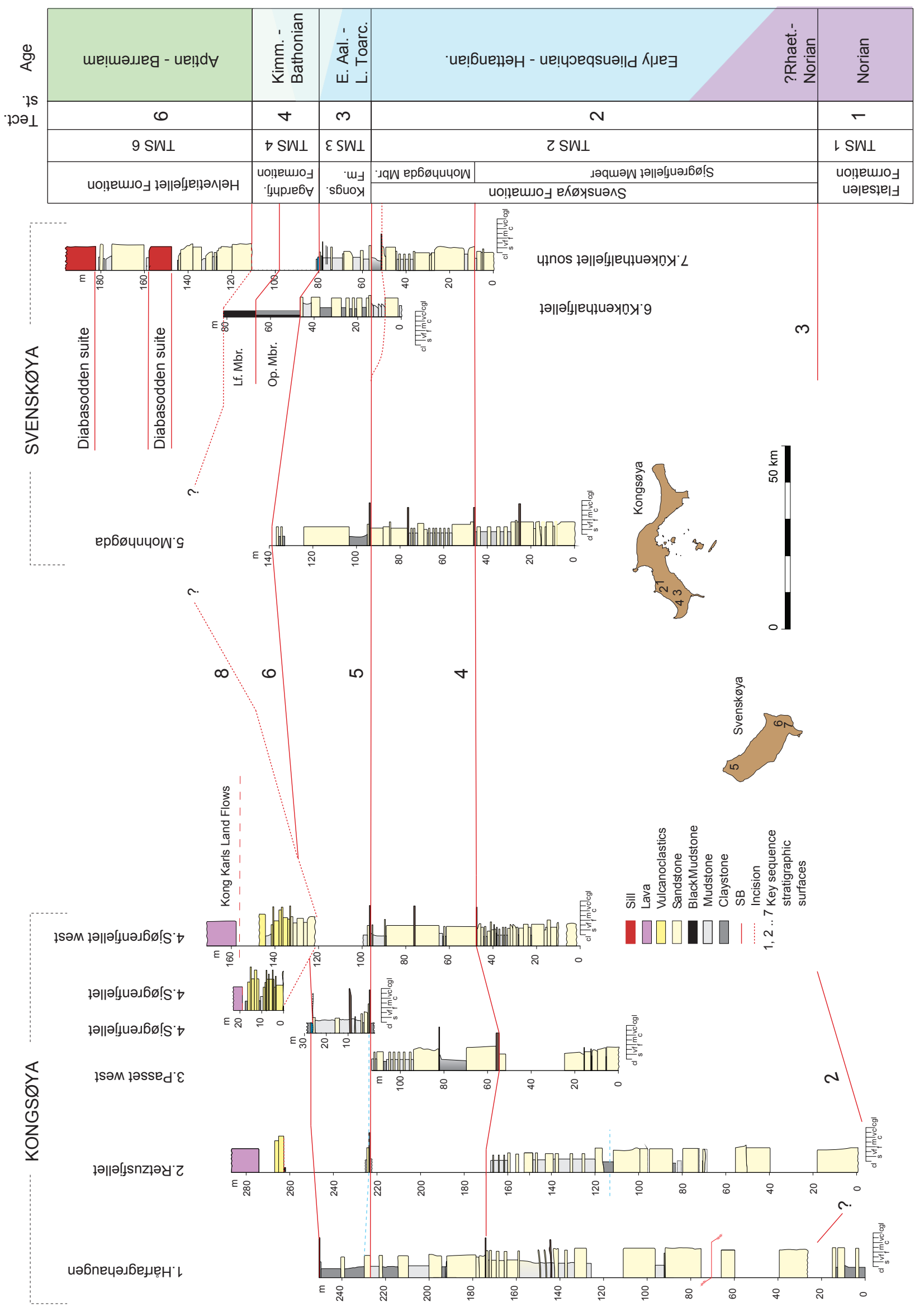




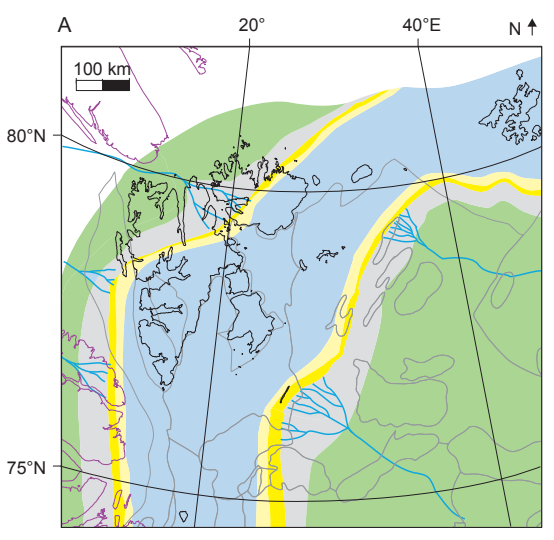

Norian-Rhaetian, Flatsalen Formation

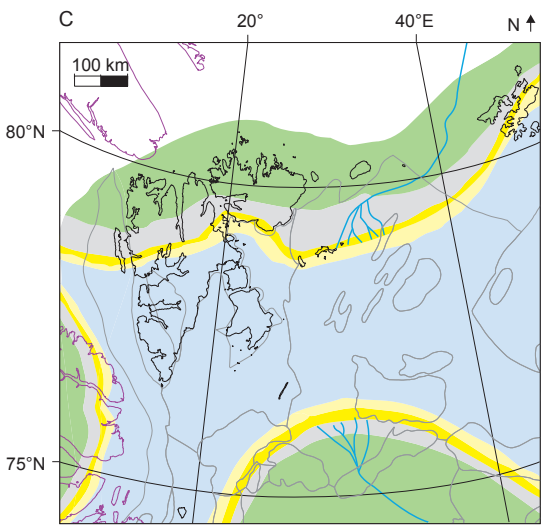

Late Pliensbachian, Mohnhøgda Member

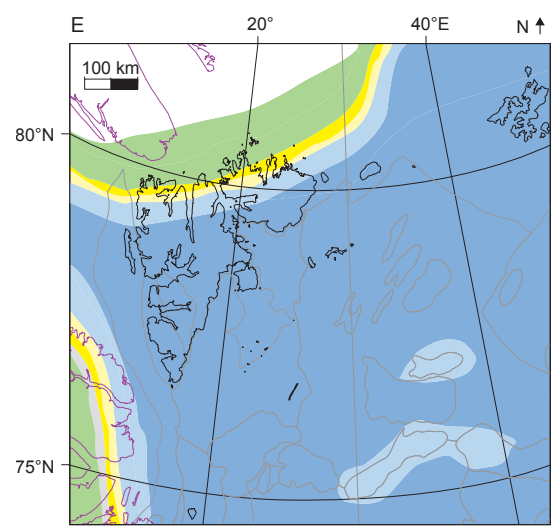

Early Kimmeridgian, Agardhfjellet Formation

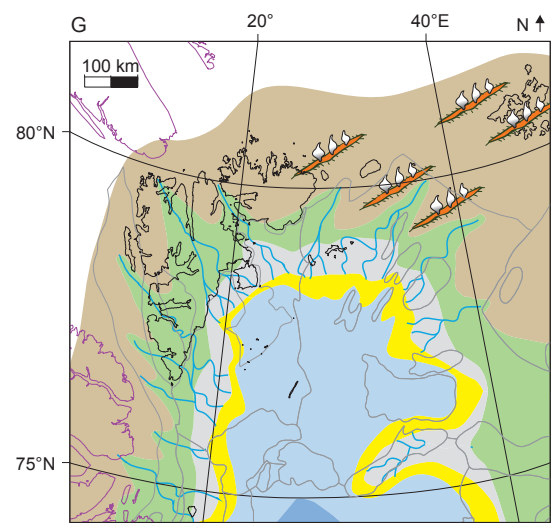

Barremian, Helvetiafjellet Formation

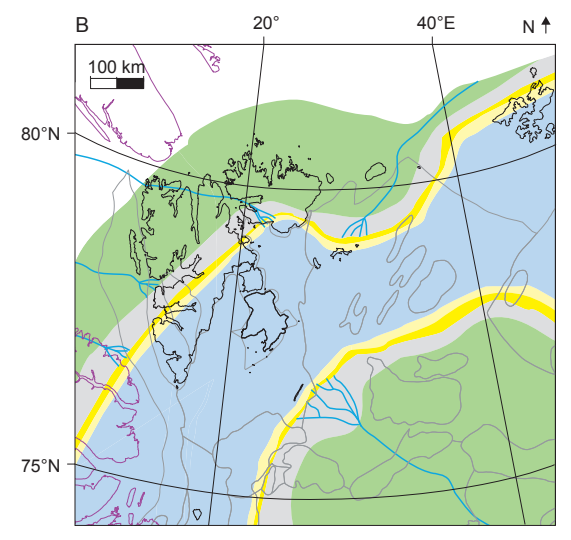

Hettangian-Early Pliensbachian, Sjøgrenfjellet Member

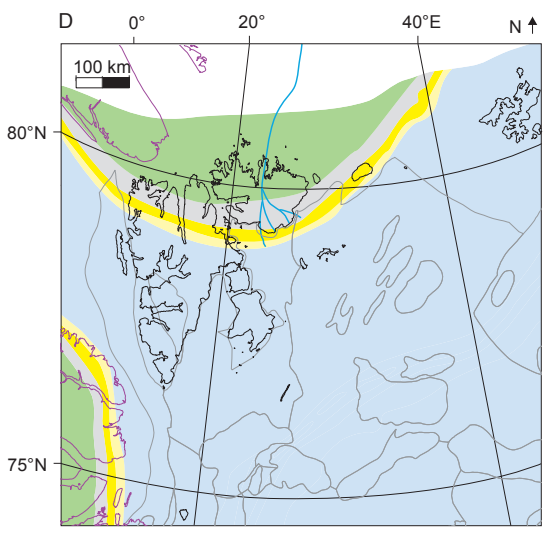

Middle Toarcian, Kongsøya Formation

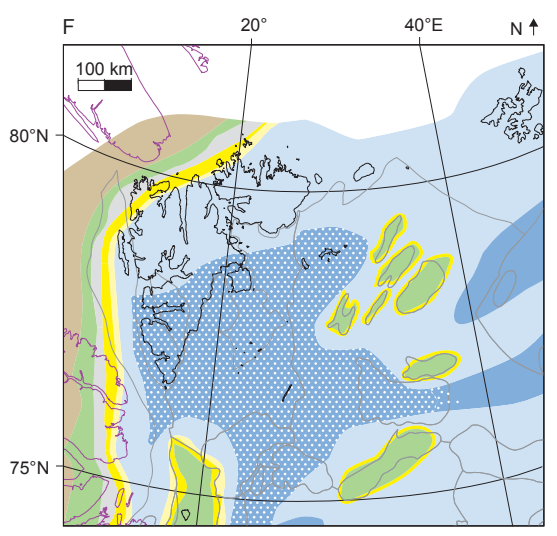

Early Valanginian, Tordenskjoldberget Member

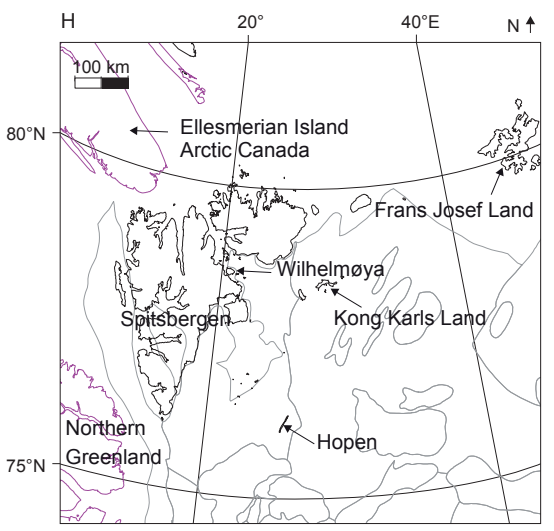

Index

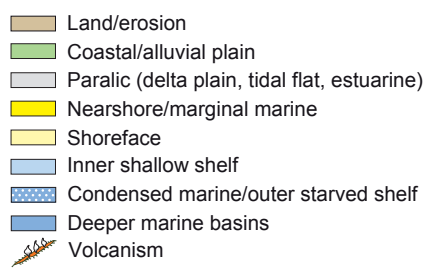

$\square$ Deeper marine basins Volcanism

Figure 33. Paleogeographic reconstruction of the Mesozoic succession in Kong Karls Land. The Early Kimmeridgian and Early Cretaceous are modified from Smelror et al. (2009), Dypvik \& Zakharov (2012) and Grundvåg et al. (2017). 
Tethyan and Boreal oceans: the pan-Arctic Early Norian flooding event (Mørk, 1989; Embry \& Johannessen, 1993; Embry, 1997; Skiold et al., 1998; Mørk \& Smelror, 2001; Worsley, 2008).

\section{Age}

The Flatsalen Formation on Hopen conformably overlies the deltaic/paralic De Geerdalen Formation of Late Carnian to earliest Norian age (Vigran et al., 2014), suggesting that the base of the Flatsalen Formation is close to the Carnian/Norian boundary (Smith et al., 1975; Mørk et al., 1999, 2013). Recent studies have dated the Flatsalen Formation on Hopen and in Kong Karls Land to Early Norian (Vigran et al., 2014; Paterson \& Mangerud, 2015; Smelror et al., 2018).

\section{Facies}

On Hopen, the formation represents a typical transgressive-regressive unit with a lower transgressive system tract, consisting of shoreline deposits with a transgressive lag at the base: the Slottet Bed, followed by a coarsening and shallowing upwards, giving a regressive system tract (Fig. 8). The relatively thin approximately 10 to 15 m-thick CU units in the Flatsalen Formation on Hopen suggest that they are shoreline or deltaic clinoforms (cf., Helland-Hansen \& Hampson, 2009). The formation in Kong Karls Land shows a similar CU trend to Hopen, with gradually coarser-grained, shallowingupwards units. However, here the Flatsalen Formation is represented by a more proximal shoreline facies.

\section{Sequence-stratigraphic expression of the surfaces}

The base of the Flatsalen Formation (key sequencestratigraphic surface 1, Table 2) (see also Figs. 8 \& 9) is not exposed in Kong Karls Land. Correlation with the Flatsalen Formation on Hopen and Wilhelmøya, and seismic interpretation suggests that a maximum of 60 metres can be added to the lowermost exposures on Kong Karls Land. On Hopen, the base of the Slottet Bed has a sharp boundary to the underlying paralic De Geerdalen Formation (Figs. 8 \& 9). The erosive character of the Slottet Bed is well defined in central and eastern parts of Spitsbergen (Mørk et al., 1999). Here, the Slottet Bed is floored by a polymict quartz and phosphatic pebble or gravel lag which erodes into fluvial deposits, calcrete palaeosols and red beds of the De Geerdalen Formation (Rismyhr et al., 2019). This surface is followed by shoreline deposits, suggesting that it is a shoreline ravinement unconformity (cf., Embry, 2009a). A ravinement surface between the Norian Fruholmen and Carnian Snadd formations has also been described in the southern Barents Sea (Bugge et al., 2002). On Hopen, the base of the Slottet Bed is followed by a $20 \mathrm{~cm}$-thick bed of darker grey, more organic-rich and pyritic mudstone and less burrowed mudstone, suggesting that this mudstone represents the maximum flooding surface, MFS (Fig. 8).

Offshore seismic expression of the sequence The base of the Flatsalen Formation, the Slottet Bed, is correlated to the base of seismic unit A (Figs. 5A, $6 \mathrm{~A} \& \mathrm{7})$ : the boundary between an overlying unit with heterogeneous, commonly dipping, discontinuous reflectors, and an underlying unit with more continuous, planar reflections. The segment of seismic line 3000-90 (Fig. 5B) demonstrates how this seismic boundary is truncated by the sea floor. The boundary is interpreted as the base of a coarsening-upward sequence and it appears to be located deeper than the stratigraphically deepest exposures on Kong Karls Land. Given seismic velocities of around $2000-2500 \mathrm{~m} / \mathrm{s}$, the base of the Flatsalen Formation is calculated to be $40-60 \mathrm{~m}$ below the stratigraphic lowest exposure on Kong Karls Land. Acquired seismic in the Norwegian Barents Sea shows that the boundary between the underlying Snadd Formation and the overlying offshore counterpart to the Flatsalen Formation, the Fruholmen Formation, is a seismic marker with a prominent impedance contrast. This is also defined as a seismic stratigraphic boundary (Riis et al., 2008).

\section{Regional development and palaeogeography}

The Slottet Bed at the base of the Flatsalen Formation represents the Early Norian Pan-Arctic transgression. Offshore southwest Barents Sea, the base Fruholmen Formation comprises marine to prodelta mudstones, marking a widespread transgression during Early to Middle Norian times, followed by progradation of sandy delta systems, apparently from a number of point sources along the basin margins (Berglund et al., 1986; Henriksen et al., 2011).

Norian sediments in western Spitsbergen are interpreted as sourced from northern Greenland (Fig. 33A) and palinspastic reconstructions indicate that these areas were close to Spitsbergen at that time (Mørk et al., 1982; Steel \& Worsley, 1984; Nøttvedt et al., 1993; Нøy \& Lundschien, 2011; Bue \& Andresen, 2013).

\section{TMS 2. Late Norian/Early Rhaetian-Early Toarcian}

TMS 2 is linked to the initiation of Late Norian to Early Rhaetian compressional tectonics, tectonic stage 2, from the Taimyr and Novaya Zemlya fold-and-thrust belt (cf., Faleide et al., 2017). Particularly the eastern Barents Sea experienced the influence of the developing Novaya Zemlya Fold-and-Thrust belt (Lopatin et al., 2001; Buiter \& Torsvik, 2007; Petrov et al., 2008; Scott et al., 2010). Angular unconformities at the Triassic-Jurassic transition are documented in regional seismic data and well logs from the subsurface Barents Sea by Müller et al. (In review) and linked to hiatuses coeval to the Novaya Zemlya Fold and Thrust Belt. One of the main regional unconformities within the Mesozoic in Svalbard is linked to this stage, herein informally termed the Rhaetian unconformity. This unconformity also marks a major change in facies and drainage patterns. On Hopen, the 
unconformity is seen as a subaerial erosive surface where underlying lower shoreface or transition zone deposits are eroded by fluvial deposits (Lord et al. in press). In Svalbard and probably the northern Barents Sea, the drainage trends also change; while the northwestward progradational trends persist, additional input from north and west can also be recognised. This second major tectonic stage is also recognised by a provenance shift from east to north in Svalbard (Rismyhr et al., 2019) and by a more complex drainage on the platform areas in the Barents Sea i.e., from Fennoscandia, Greenland and local highs (Smelror et al., 2009; Henriksen et al., 2011; Klausen et al., 2016, 2017b). Recent studies by Smelror et al. (2018) also note a Rhaetian Lower Hettangian hiatus on Franz Josef Land.

This basin fill in Kong Karls Land comprises the Svenskøya Formation of the Wilhelmøya Subgroup and the Tubåen and Nordmela formations on the Kong Karls Platform. In Kong Karls Land there is a 200 m-thick almost complete Rhaetian to Toarcian succession, which is in contrast to the 5 to $20 \mathrm{~m}$-thick, condensed or eroded units with several hiatuses or lacunas on western and central Spitsbergen (Fig. 34) (Bäckstrøm \& Nagy, 1985; Krajewski, 1990; Nagy \& Berge, 2008; Rismyhr et al., 2019).

The seismic data show the same trend, where the offshore areas nearby Kong Karls Land were part of a region in the northern Barents Sea, with a thicker preserved RhaetianPliensbachian succession than that on Spitsbergen and the platform areas to the south, suggesting higher subsidence rates. The onlapping character of the Svenskøya Formation as seen in the cross section in Fig. 34 is also indicated in seismic line 3000-90 (Fig 5B).

During this time, Spitsbergen periodically acted as a structural high, with a somewhat thicker succession, from less than $10 \mathrm{~m}$ in the west to approximate $40 \mathrm{~m}$ on the east coast of Spitsbergen. This suggests a slightly periodically tilted structure towards the east or northeast. Lopatin et al., (2001), Buiter \& Torsvik (2007) and Scott et al. (2010) document Late Triassic to Early Jurassic regional folding in Novaya Zemlya and the Admiralty High (Fig. 35) associated with major thrusting on Novaya Zemlya, i.e., the Novaya Zemlya Fold-and-Thrust Belt (Ritzmann \& Faleide, 2009). Stoupakova et al. (2011) also marks an unconformity in the Rhaetian linked to the major thrusting on Novaya Zemlya. These recorded unconformities in the Barents Sea are also accompanied by active volcanism as indicated by detrital zircon studies from the Fruholmen and Tubåen formations in the SW Barents Sea giving $\mathrm{U}-\mathrm{Pb}$ ages $210.4 \pm 1.9 \mathrm{Ma}$, i.e., near the Norian-Rhaetian boundary (Klausen et al., 2016).

At the same time, rifting in the Kara Sea shows that extensional deformation took place as the Novaya Zemlya Fold-and-Thrust Belt developed (Nikishin et al., 2002). This event corresponds to the subaerial erosive surface between the Norian Flatsalen and the
Rhaetian Svenskøya formations (Figs. 8 \& 9) (Lord et al., in press) and the offshore equivalent boundary between the Fruholmen and overlying Tubåen formations (Gjelberg et al., 1987). The final westward movement (i.e., thrusting; up to the west) of Novaya Zemlya occurred in Rhaetian to Early Jurassic (Petrov et al., 2008; Faleide et al., 2017). The eastern flank of the East Barents Basin was uplifted becoming the source for latest Triassic and Early Jurassic sediments (Drachev et al., 2010). During this time, inversion, i.e., uplift and folding of the Admiralty High, led to formation of two depocentres; a northern and a southern Barents Basin separated by the Ludlow saddle (Drachev et al., 2010; Stoupakova et al., 2011; Drachev, 2016).

Kong Karls Land is situated in the westernmost part of the area between Svalbard and the depocentre of the northern Barents Basin and may have been located on a western limb of this depocentre, i.e., a sag basin situated $800 \mathrm{~km}$ northwest of the present western coastline of Novaya Zemlya. Westward translations of the Novaya Zemlya thrust-sheets were in the order of 100 to $200 \mathrm{~km}$ (Buiter \& Torsvik, 2008; Drachev et al., 2010). Although based on a scattered and low-resolution seismic grid, a hypothesis based on the prominent difference in preserved strata and thickness between Spitsbergen and Kong Karls Land might be related to a response of the nappe tectonics recorded by the Novaya Zemlya tectonic phase (Olaussen \& Rismyhr, 2016). Using the terminology of DeCelles \& Giles (1996), the Kong Karls Land and Kong Karl platform might then be part of the forebulge to foredeep slope of the North Barents Sea Basin, or alternatively, a part of the forebulge to backbulge zone (Fig. 35). In southern Barents Sea Lower Jurassic unconformities are interpreted to be a result of compression-induced forebulge uplift at the TriassicJurassic transition. (Müller et al. in review).

However, the long distance from the recorded nappe tectonics to Svalbard, and partly unknown nappe thickness, require further investigation. A size-wise analogue is the Albian to Santonian basin fill of the western interior of the USA (Cross, 1986; Pang \& Nummedal, 1995). Regardless of process, it is likely that the Norian to Aalenian basin infilling and development of some of the key sequence-stratigraphic surfaces in Kong Karls Land were mainly controlled by tectonism in the E-NE.

\section{Sequence stratigraphy of the Svenskøya Formation}

The sequence boundary of TMS 2, the key sequencestratigraphic surface 3 , is well exposed on Hopen and also defines the lithostratigraphic boundary between the Flatsalen and Svenskøya formations (Mørk et al., $1999,2013)$ and is herein informally named the Rhaetian unconformity. The upper boundary is the base of the Kongsøya Formation. TMS 2 is also subdivided into two or three higher-frequency sequences. These are the Sjøgrenfjellet Member with lower sequence boundaries 


\begin{tabular}{|c|c|c|c|c|c|}
\hline SWI & $\theta$ & $m$ & \multicolumn{2}{|r|}{$\sim$} & - \\
\hline $\begin{array}{c}\text { słlun } \\
\text { อлочsमо }\end{array}$ & 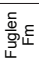 & $\begin{array}{l}\text { Iaddn } \\
\text { Ipp!w }\end{array}$ & 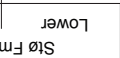 & 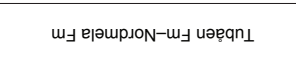 & 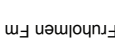 \\
\hline $\begin{array}{l}\text { Kuded6 } \\
-12 e, 15\end{array}$ & 这E & 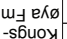 & qW ербөчичо & 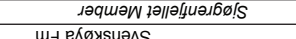 & $\mathrm{m}_{\unlhd}$ uәреsłе \\
\hline $26 \forall$ & 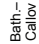 & 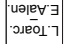 & 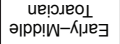 & 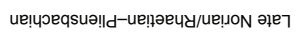 & 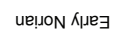 \\
\hline
\end{tabular}

$<$
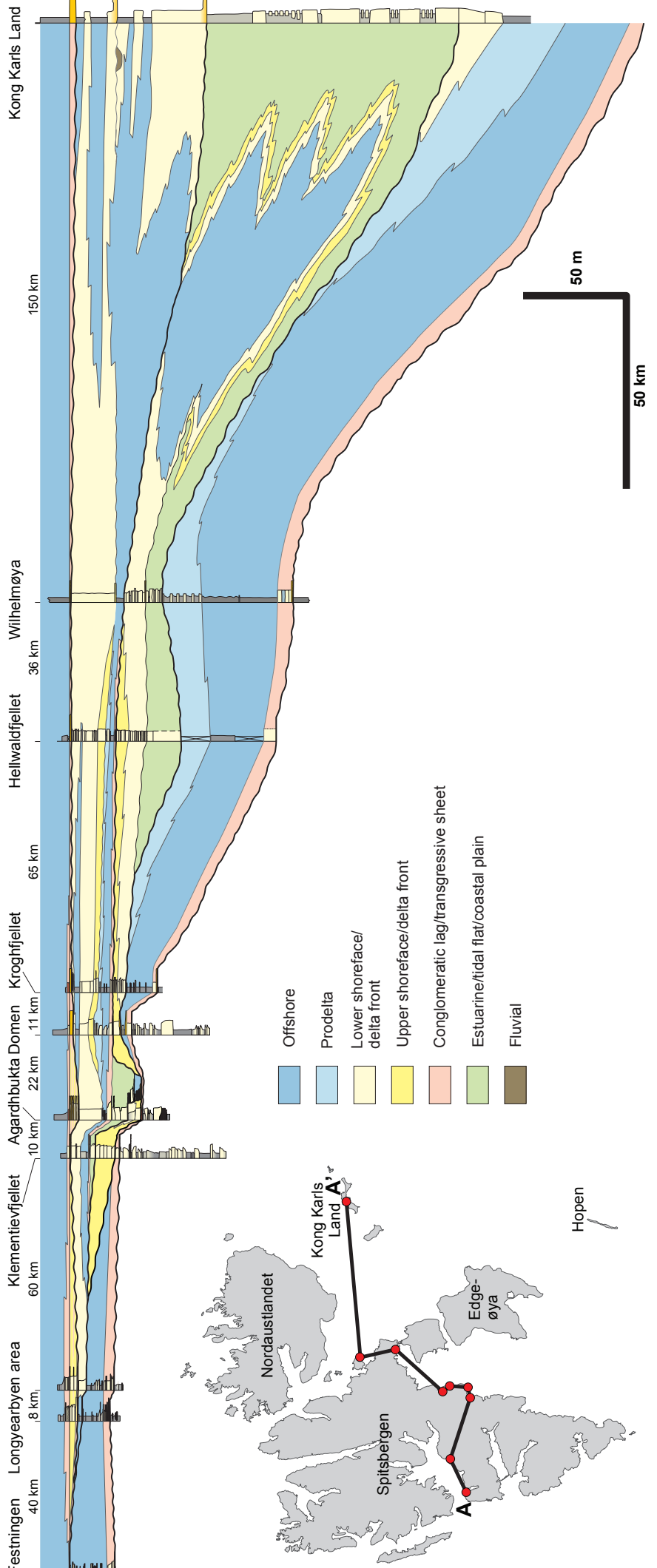

4

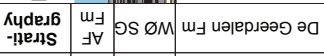

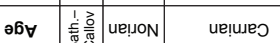

corresponding to the key sequencestratigraphic surface 3 and the Mohnhøgda Member which has the key sequencestratigraphic surface 4 as the lower boundary. In addition, a third sequence can be defined in the upper part of the Mohnhøgda Member which is only seen locally as a suggested incised surface (Figs. $17 \& 18)$.

\section{Age}

The basal boundary of the Svenskøya Formation on Hopen is problematic but tentatively dated as Rhaetian (Paterson \& Mangerud, 2015; Paterson et al., 2016). In Kong Karls Land, the lower $12 \mathrm{~m}$ of Sjøgrenfjellet Member contains typical Norian-Rhaetian palynoflora elements, whereas Rhaetian-Hettangian indicators are observed in the middle part of the formation (Smelror et al., 2018). The upper part of the unit is suggested to be of Sinemurian/Early Pliensbachian age (Smelror et al., 2018). Reworked Permian and Early Triassic species are also seen.

Palynology gives a Late Pliensbachian to Early Toarcian age for the Mohnhøgda Member which is suggested to have been deposited at or near the global Late Pliensbachian to Early Toarcian flooding event (Smelror et al., 2018). The occurrence of Mancodinium semitabulatum limits the base of the member to the Late Pliensbachian or younger and therefore the biostratigraphic information does not indicate a recognisable hiatus.

Facies

The depositional environment of the Sjøgrenfjellet Member is interpreted to represent a fluvio-deltaic or coastal plain passing upward to a tide-dominated estuary (Fig. 11). The considerable thickness and the stacking of the inferred tidal deposits suggest a delicate balance between subsidence and sea level rise. The Mohnhøgda Member shows a significant change in depositional environment from the protected tidally-dominated environment of the Sjøgrenfjellet Member, to more open wave-dominated conditions with a shoreface to offshore transition to offshore deposits (Fig. 15). In the Kükenthalfjellet area, a bay-head delta deposit with a distributary channel is recognised in the upper part of the member. Although containing more marine palynofacies (Smelror et al., 2018) 

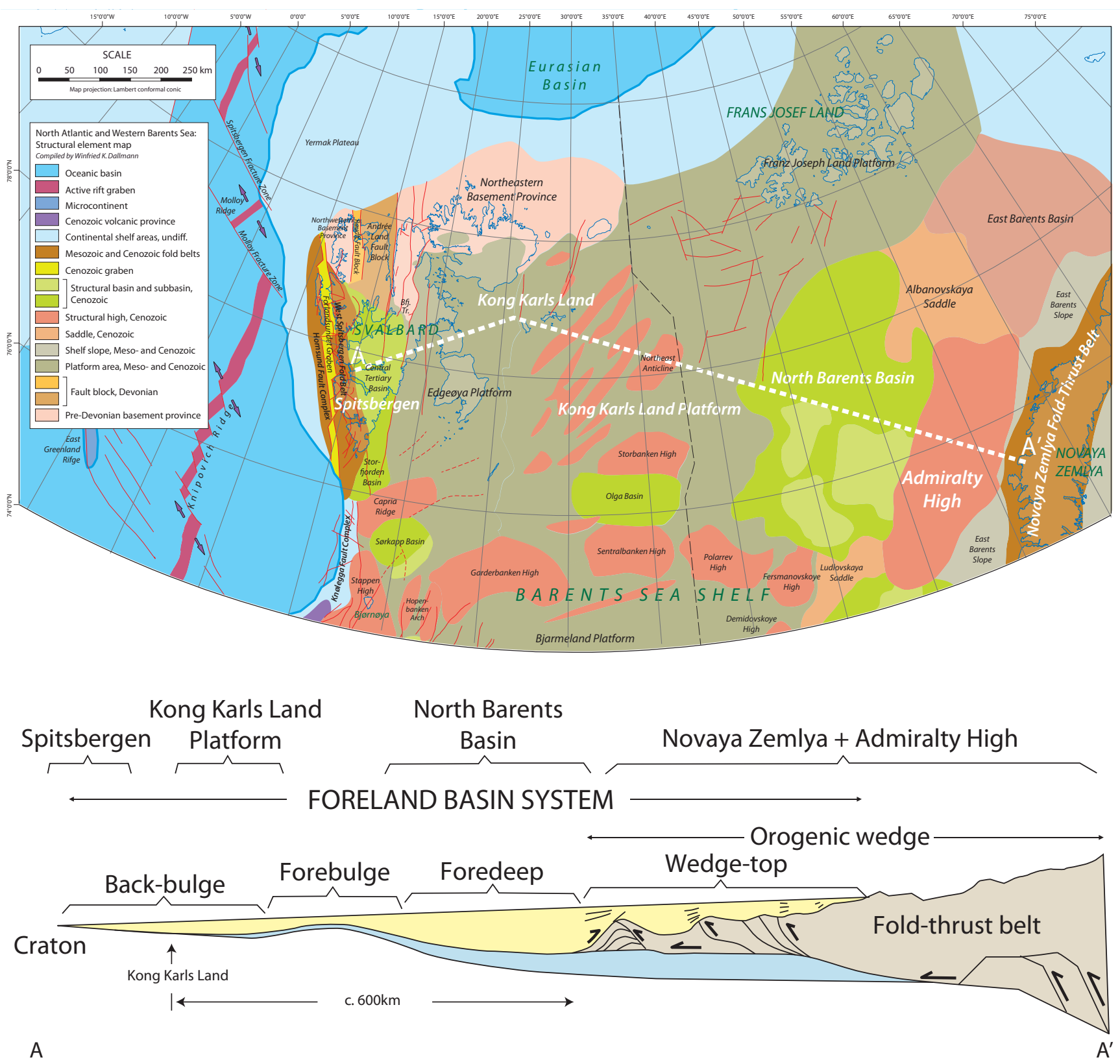

Figure 35. Conceptual and speculative model for the Late Norian to Early Pliensbachian basin fill based on DeCelles \& Giles' (1996) foreland basin model. Map: Svalbard and oceanic areas based on Dallmann et al. (2015).

and wave-generated structures than the underlying Sjøgrenfjellet Member sequence, common fresh and brackish/marginal marine palynomorphs suggest overall low salinity levels, presumably as a result of nearby river discharge.

\section{Sequence-stratigraphic surfaces}

The lower sequence boundary of TMS 2 is not exposed in Kong Karls Land. The description is thus based on outcrops on Hopen and Wilhelmøya (Lord et al., in press). There, the sequence boundary surface is seen as a channel lag overlain by coarse-grained, trough cross-stratified, fluvial sandstones (Lord et al., 2014). It erodes into the shoreface deposits of the underlying Flatsalen Formation (Figs. $8 \& 9$ ), and is defined as a subaerial unconformity (SU). On Hopen only the lowest $48 \mathrm{~m}$-thick succession of TMS 2 is preserved due to Cenozoic uplift and erosion. The Svenskøya Formation on Hopen comprises an overall fining-upward unit with amalgamated cross-stratified conglomerate and sandstone beds with plant fragments, which are interpreted as a fluvial channel fill, passing upwards into tidal bars (Lord et al., in press). The revised stratigraphy of the Wilhelmøya Subgroup by Mørk et al. (1999) together with the initial description by Worsley (1973) suggests a similar basal unconformity on Wilhelmøya.

The probable fluvial channel near the base of the Sjøgrenfjellet Member in Kong Karls Land is overlain by tidal deposits. The upper part of the Sjøgrenfjellet 
Member on Hårfagrehaugen consists of a CU unit interpreted as part of a prograding bay-head delta and might be regarded as a lower hierarchy sequence, e.g., a parasequence. The sharp boundary surface to the overlying Mohnhøgda Member is expressed by a poorly sorted gravel bed with quartz grains and shell fragments of ostracods (Fig. 15) followed by a shoreface deposited sand. The boundary is the key sequencestratigraphic surface 3 (Table 2) and is interpreted as a wave ravinement surface.

Most of the logged sections of the Mohnhøgda Member in Kong Karls Land show no clear coarsening-upward or fining-upward trend. Some localities show shoreface deposits passing upward to the transition zone. At other localities, as for example at Kükenthalfjellet, the upper part is represented by a bay-head delta of a probable lower hierarchy sequence (Figs. 17 \& 18A). While the Sjøgrenfjellet Member can be seen as an aggrading tidal deposited unit, the Mohnhøgda Member is clearly more marine and a general transgressive or back-stepping trend is suggested for the Svenskøya Formation as a whole.

\section{Offshore seismic expression of the sequence}

Immediately offshore Kong Karls Land there is no clear seismic boundary between TMS 1 and 2; the Flatsalen and Svenskøya formations. In contrast, truncation of parallel, high-amplitude reflectors of the underlying Fruholmen Formation is observed on the highs and platforms in the southwestern Barents Sea. Close to the Kong Karls Land, a weak reflector seen in some lines may represent the top of Seismic Unit A, corresponds to the top of TMS 1. As this reflector is difficult to map regionally, the two seismic sequences representing the Flatsalen Formation and the Sjøgrenfjellet Member are therefore combined as seismic unit A/B. Seismic Unit A/B typically displays trough-shaped features of comparable size and frequency on both east-west, northsouth and oblique seismic lines (Fig. 5). The seismic grid is too sparse to correlate these troughs from line to line, and no preferential regional direction for the trough structures can be seen.

Figs. 5B \& 7 display the thickness variation of Seismic Unit $A / B$ and its truncation at the sea floor. In areas with igneous rocks it is impossible to identify this unit (Fig. 7). Hence, jump correlation is necessary, but the overall trend in the map seems reasonable. The combined Seismic Unit A/B is thickest to the north and east of Kong Karls Land, gradually decreasing from approximately 300 $\mathrm{ms}$ in the N-NE to about $200 \mathrm{~ms}$ at $78^{\circ}$ north, south of Kong Karls Land. The map indicates a gradual thinning towards the west and south, but the data coverage is too poor to document a clear trend in this direction. The thinning of the unit is accompanied by internal seismic facies changes from north to south. Troughs and discontinuous reflectors dominate in the north, whereas the internal reflectors in the south are more continuous, with frequent wave features but without erosive forms (Fig. 7).

The Mohnhøgda Member correlates with seismic unit C consisting of parallel continuous reflectors with relatively high amplitudes (Figs. 5 \& 7). Seismic unit C is about 50 ms thick in the vicinity of the islands and is more or less constant throughout the area. This is compatible with the mean thickness of $55 \mathrm{~m}$ found on Kongsøya. A westwards thinning of this unit is predicted because of the lower thicknesses demonstrated onshore Spitsbergen, but this is difficult to verify due to limitations in accessible data and the fact that the unit is truncated against the sea bottom towards the west (Grogan et al., 1999).

\section{Regional development and palaeogeography}

In the Hammerfest Basin, the fluvial to deltaic deposits are overlying the Norian succession, the Fruholmen Formation (Berglund et al., 1986; Gjelberg et al., 1987). Within the lower part of the Rhaetian succession a hiatus with a sharp boundary is overlain by fluvial sandstones of the Tubåen Formation (Gjelberg et al., 1987). This is here suggested to represent the same sequence boundary as TMS 2. A Rhaetian unconformity is recorded on the basin margins in the Hammerfest Basin (Mulrooney et al., 2018) and throughout the Bjarmeland Platform (Ryseth, 2014). In the coastal areas on eastern Spitsbergen, the time-equivalent boundary is seen with a maximum erosional relief of $10 \mathrm{~m}$ which erodes into the Flatsalen Formation.

The Sjøgrenfjellet Member was deposited at a time when a widespread coastal and tidal, delta plain developed over more or less the entire Barents Sea area; particularly well documented in southwestern Barents Sea (Olaussen et al., 1984; Berglund et al., 1986; Gjelberg et al., 1987; Henriksen et al., 2011; Ryseth, 2014; Klausen et al., 2017b). The drainage area for the Rhaetian to Lower Pliensbachian succession in the Barents Sea and in Svalbard is controversial (Lundschien et al., 2014; Klausen et al., 2016). Based on scattered palaeocurrent measurements in Kong Karls Land we suggest the presence of a land area to the northeast and north (Figs. $14,18 \& 33$ ) This land area might be a continuation of the postulated Crocker Land north of the Sverdrup Basin (Embry, 1993, 2009b) or Arctida (Metelkin et al., 2015).

Our tentative palaeogeographic reconstruction of the northwestern Barents Sea in Hettangian to Early Pliensbachian times (Fig. 33B) suggests a tidally dominated coastline stretching from Spitsbergen in the west through Kong Karls Land to Hopen in the south. East of this coastal belt, widespread coastal and delta plains with possible localised minor erosion developed in the Storbanken and Sentralbanken areas. Sediment supply from Greenland is thought to have been limited (Bue \& Andresen, 2013). On Franz Josef Land (cf., map, Fig. 1), continental deposits of Norian/ Rhaetian age characterise the Vasiliev and the Tegelthoff 
suites (Diebner, 1998), but their continuation into Early Jurassic time is uncertain. Horn (1932), Diebner (1998) and Embry (1994) indicated an Early Jurassic age for the uppermost parts of the continental package of the Tegelthoff Suite, whereas Elverhøi et al. (1988; their Fig. 3) have suggested that the Lower Jurassic is completely missing and that Middle Jurassic claystones rest unconformably on Upper Triassic sandstones. This is also in line with Smelror (1986). Diebner (1998) reported about 200 m-thick Lower Jurassic sandy deposits lithostratigraphically almost indistinguishable from the underlying, terrigenous Norian-Rhaetian beds. On Spitsbergen, the shallow-marine platform of the Wilhelmøya Subgroup continued to develop with deposition of thin, condensed, shaly sandstones and with intervening erosional episodes (Mørk et al., 1982; Steel \& Worsley, 1984; Nagy \& Berge, 2008; Nagy et al., 2011). A gradual retreat of the coastline is suggested in Late Pliensbachian (Fig. 33C), especially across the relatively flat coastal plain areas along the eastern margin of the basin. Zircon studies in the southwestern part of the Barents Sea reveal a complex drainage pattern, probably reflecting reworking (Klausen et al., 2017b).

\section{TMS 3. Late Toarcian-Early Aalenian}

Tectonic megasequence 3 (TMS 3) was formed during Late Pliensbachian to Early Aalenian times. In Kong Karls Land. TMS 3 comprises the Kongsøya Formation. By Late Pliensbachian to Early Toarcian times the eastwest thickness difference as seen in Norian to Early Pliensbachian is diminishing, suggesting a slowing down of subsidence, and by Early Aalenian time it had levelled out (Fig. 34) and the basin fill is represented by thin condensed units throughout Svalbard (Bäckstrøm \& Nagy, 1985, Mørk et al., 1999; Rismyhr et al., 2019). The thin preserved strata on Svalbard now reflect erosion, reworking of previous strata (Bäckstrøm \& Nagy, 1985) and incision and development of large hiatuses (Rismyhr et al. 2019). During this tectonic stage, stage 3 , the structural high around Svalbard was probably still slightly tilted to the northeast, with periodic subaerial exposure. Also in platform areas in the Barents Sea the Upper Pliensbachian-Aalenian succession is dominated by uplift, erosion and condensation with several hiatuses (Klausen et al., 2017b). Probably the uplift is related to larger reorganisation of the northwestern corner of the Eurasian plate where Svalbard became almost sandwiched during the initial rifting in the Middle Jurassic to Lower Cretaceous North Atlantic rift system (cf., Faleide et al., 2008). In the north, the mid-Jurassic rifting related to the proto-Amerasia Basin was initiated (Embry, 2011). In Kong Karls Land, TMS 3 is represented by the Kongsøya Formation.

\section{Sequence stratigraphy of the Kongsøya Formation}

TMS 3, representing the Toarcian to Aalenian Kongsøya Formation, is bounded at the base by key sequence- stratigraphic surface 4 . The upper boundary is defined by the Bathonian flooding surface at the base of the Agardhfjellet Formation.

\section{Age}

A Late Toarcian to Early Aalenian age is indicated for the Kongsøya Formation (Smelror et al., 2018). The upper boundary in Kong Karls Land is of Early Aalenian age. Bajocian strata are missing on Svalbard (Smelror et al., 2018).

Facies

The Kongsøya Formation reveals a 20-30 m-thick unit of lower shoreface to condensed offshore/ innershelf deposits throughout Kong Karls Land (Figs. 19 \& 20). Common glauconite-rich sandstone beds and beds composed entirely of belemnites suggest that this represents a highly condensed unit (Fig. 19B). Scattered preserved, hummocky cross-stratified beds indicate an offshore to transition zone depositional environment (Figs. 19 \& 20A). The Kongsøya Formation is correlative throughout Kong Karls Land, Wilhelmøya and partly on Spitsbergen.

Sequence-stratigraphic expression of the surfaces The base of the Kongsøya Formation contains a distinct gravel bed (Figs. 19 \& 20C), consisting of glauconite, quartz, chert, siderite and quartz gravel with wood and coal fragments. The gravel bed contains a brackish water fauna (Smelror et al., 2018). The common wood, coal and brackish fauna suggest that they are remains of a paralic deposit. The basal conglomerate of the Kongsøya Formation is interpreted as a remanie deposit (reworked continental deposits), suggesting that the base of TMS 3 (key sequence-stratigraphic surface 4) is represented by a subaerial unconformity (SU). This is a sequencestratigraphic surface of regional significance, close to the proposed global, high-latitude Pliensbachian-Toarcian turnover, viz. a regression followed by a transgression (Zakharov et al., 2006; Wignall \& Bond, 2008), as recently proposed in the Hammerfest Basin (Hess et al., 2014).

\section{Offshore seismic expression of the sequence}

The Kongsøya Formation is correlated with seismic Unit D. The correlation is best close to Kong Karls Land, where seismic Unit D is $25-50 \mathrm{~m}$ thick. Seismic Unit D has no clear internal reflectors and where the unit subcrops, the sea floor is gently inclined or flat. The correlation is uncertain southeast of the anticline east of Kong Karls Land, but interpretation indicates a unit thickness of $30 \mathrm{~ms}$ along seismic line 3000, south of 78³0' (Fig. 5B). Towards the east and south, seismic Unit D seems to thin. Here it is difficult to distinguish the base of seismic unit E from the top of seismic Unit C.

\section{Regional development and palaeogeography}

The middle and upper Stø Formation in the Hammerfest Basin is time equivalent to the Kongsøya Formation. The coarser-grained and mineralogically more mature quartz 
arenites of the Stø Formation reflect more proximal and higher-energy depositional conditions (Olaussen et al., 1984; Berglund et al., 1986) than the Kongsøya Formation. The Kongsøya Formation on Wilhelmøya with up to very coarse-grained, cross-stratified sandstone, pockets with chert and quartz-pebble conglomerates and scattered belemnites, is interpreted as representing deltafront or shoreface deposits with similarities to the upper part of the Stø Formation. The more proximal facies in the west and northwest might then indicate that the Kongsøya Formation in Kong Karls Land was situated in a more distal or central basin position. On platform areas and intra-basin highs in the southern Barents Sea, equivalent units are also condensed.

A palaeogeographic reconstruction for the Middle Toarcian-Aalenian in the northwestern Barents Sea is shown in Fig. 33D. Continued transgression resulted in significant expansion of the marine seaways, especially in the eastern Barents Sea and the Russian South Barents Sea Depression.

\section{The Bathonian to Aptian tectonic mega- sequences; TMS 4, 5 and 6}

In contrast to the three previously defined TMS 1,2 and 3, evidence of tectonic movements is observed and mapped in Kong Karls Land. The Bathonian to Hauterivian successions were deposited during two phases of contraction, TMS 4 and 5. The ?Barremian to Aptian TMS 6 in Kong Karls Land represents regional uplift and magmatism related to the High Arctic LIP. Regionally, we suggest that TMS 6 ends near the AlbianCenomanian boundary.

A steeply dipping normal fault was observed on Hårfagrehaugen. The fault dips towards the southeast and displays a throw of about $30 \mathrm{~m}$. The fault plane is cut by the Helvetiafjellet Formation thus giving a pre-Aptian age for the extension. Normal faults are also observed in nearby offshore seismic as shown in Fig. 7. The normal faults might have been caused by minor local extensions, e.g., on anticlinal structures (Fig. 6B), or as a response to intrusive activity; see discussion below.

In Fig. 36 we have schematically and conceptually summarised the deformational events and the coeval basin fill in Kong Karls Land and on the Kong Karls Land Platform, both of which are discussed in more detail below.

\section{TMS 4. Bathonian to Kimmeridgian}

Deposition of TMS 4 took place during a weak contractional deformation forming large low-amplitude anticlines and synclines; tectonic stage 4 .

The fourth major tectonic stage was initiated by the onset of the North Atlantic rift system in the western and southwestern Barents Sea and the incipient tectonism related to the opening of the Amerasian Basin (Grantz et al., 2011). This is recognised by the absence of Bajocian deposits in Svalbard followed by a renewed, increased subsidence and subsequent flooding in the Bathonian, with development of mud-dominated outer to inner shelf deposits towards the south, southeast and east (Dypvik et al. 1991a, b; Smelror et al., 2009; Dypvik \& Zakharov, 2012; Koevoets et al., 2019). In the east, deformation increased in the Late Jurassic with the formation of contractional structures in the northern and eastern Barents Sea including the eastern islands of the Svalbard archipelago (Grogan et al., 1999). At the same time, extensional structures formed in the southwestern Barents Sea (Faleide et al., 1984, 1993). In Kong Karls Land, the Agardhfjellet Formation is the basin fill of the fourth tectonic stage. As previously described, the Upper Triassic to Middle Jurassic Wilhelmøya Subgroup on Spitsbergen with its thin preserved strata, numerous erosive surfaces, hiatuses and condensed units was deposited on a structural high (Worsley, 1973). This configuration was reversed in the Bathonian to near the boundary between the Barremian and Aptian (Fig. 37), with deposition of a thick dominantly mudstone succession which varies from up to $300 \mathrm{~m}$ in southern and western Spitsbergen and up to $220 \mathrm{~m}$ in eastern Spitsbergen (Nagy \& Basov, 1998; Mørk et al., 1999; Nagy et al., 2009; Grundvåg et al., 2017); in Kong Karls Land it varies from absent on the anticlines to approximately $70 \mathrm{~m}$ in the synclines.

Seismic correlation on the Kong Karls Platform also suggests that the offshore equivalent of the Agardhfjellet Formation (i.e., Fuglen and Hekkingen formations) is thin, probably reaching not more than $70 \mathrm{~m}$. In the seismic data from the northern Barents Sea, onlap of Lower Cretaceous strata can be clearly observed against structural highs and anticlines (Figs. 2C \& 5A). In the major synclines there is a seismic sequence that is interpreted to be shaly and which separates the Upper Jurassic organic-rich shales from the Lower Cretaceous sandstones of the Helvetiafjellet Formation (Fig. 5A). This infilling sequence is condensed or eroded on structural highs and in the Kong Karls Land outcrops. These thickness variations are consequences of the Late Jurassic compression which resulted in the formation of low-relief, large-scale, regional fold structures in Kong Karls Land and the northern Barents Sea, while the western parts of Spitsbergen continued to subside.

Grogan et al. $(1999,2000)$ defined Kong Karls Land to be part of the northern Barents Sea tectonic province and they recognised the absence of Upper Jurassic and Ryazanian strata on the anticlines as a result of post Middle Jurassic, tectonic movements, probably post Oxfordian-pre Valanginian contraction.

The Early Cretaceous synclinal infill, which can be observed in seismic data, is represented only as a thin Valanginian-Hauterivian section at one location in 


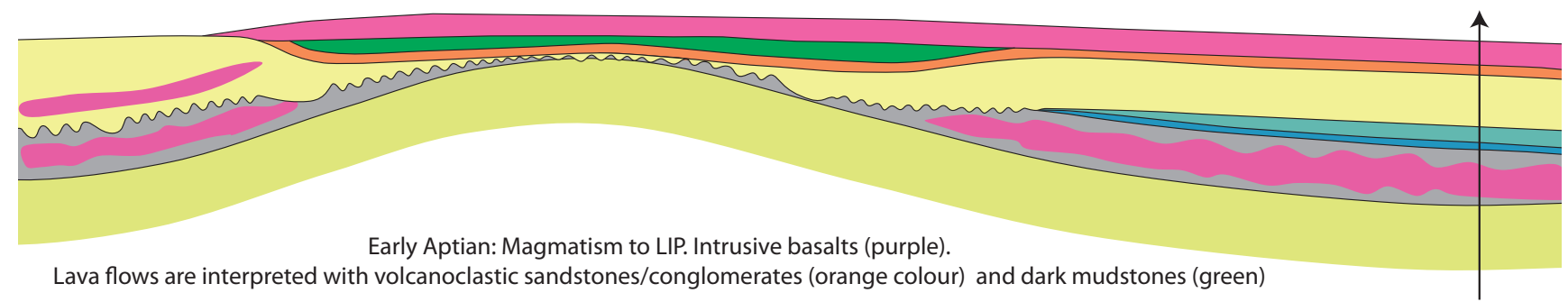

Lava flows are interpreted with volcanoclastic sandstones/conglomerates (orange colour) and dark mudstones (green)

TMS 6
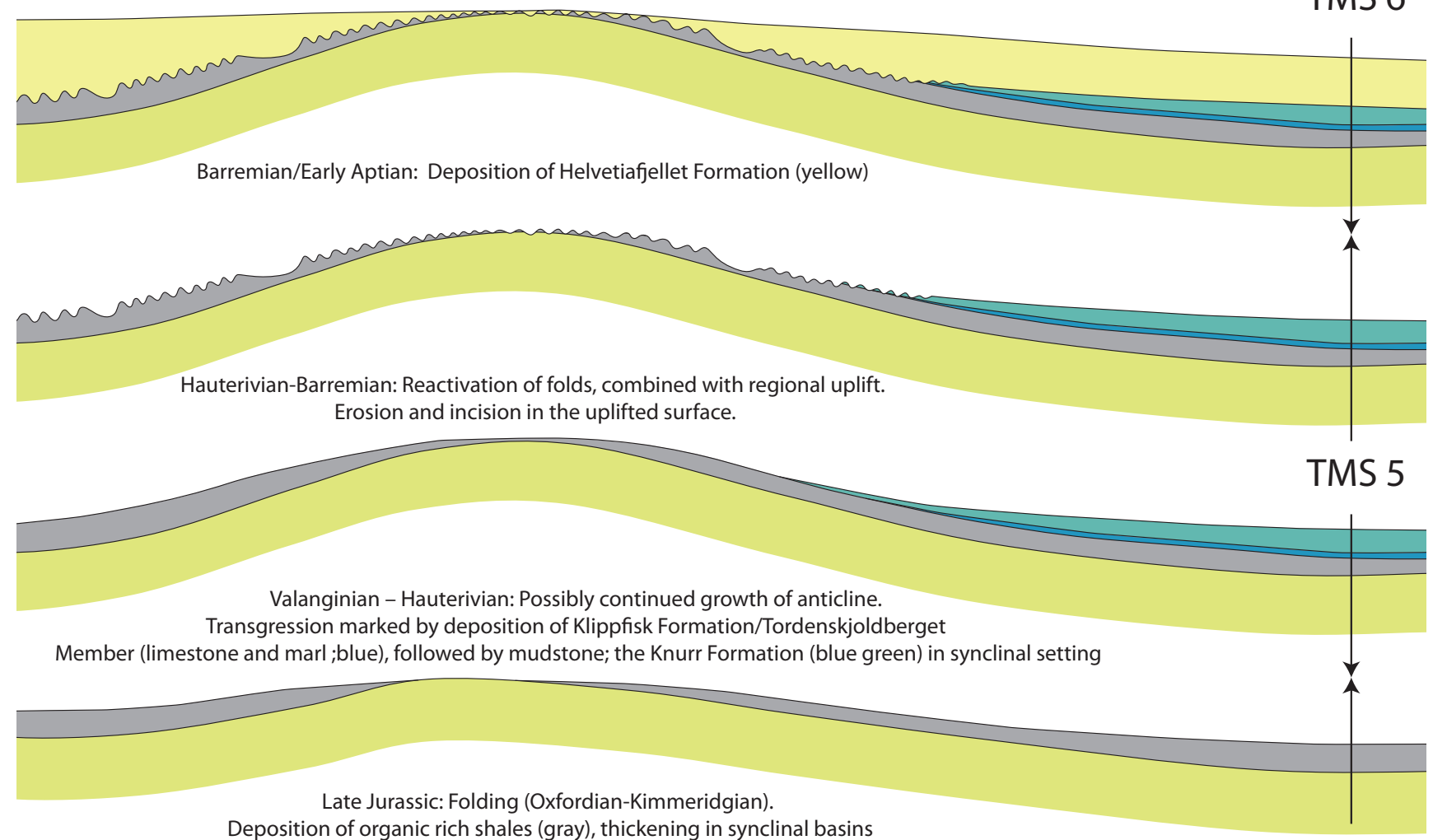

Deposition of organic rich shales (gray), thickening in synclinal basins

Figure 36. Conceptual model of Late Jurassic to Aptian tectonism in Kong Karls Land.

Kong Karls Land at the eastern flank of the Kongsøya anticline. Its stratigraphic position is equivalent to the Knurr and Klippfisk formations in the southern Barents Sea. The offshore seismic data further indicate that the Late Jurassic relief created by the first phase of folding was (partly?) infilled by the Knurr equivalent unit. In the seismic data, thicker sections of Valanginian-Hauterivian sediments are observed. The section is characterised by continuous, parallel reflectors and onlaps the BCU towards the structural highs (Fig. 5A). The top of the section is marked by the orange reflector in Fig. 5A, and the overlying part of unit $\mathrm{F}$ has a seismic character indicating more heterogeneous lithologies.

\section{Sequence stratigraphy of the Agardhfjellet Formation} The up to 70 m-thick Bathonian to Upper Kimmeridgian mudstone succession, the Agardhfjellet Formation in Kong Karls Land, defines TMS 4. The base is an important regional marker indicating an overall flooding event in Svalbard and the Barents Sea (Smelror, 1994; Worsley, 2008).

\section{Age}

The Oppdalen Member is interpreted to be of Bathonian to Callovian age, while the Lardyfjellet Member is dated from Late Callovian to Kimmeridgian (Smelror et al., 2018). Early Kimmeridgian ammonite faunas with Amoeboceras cf., kitchini, Rasenia and Aulacostephanus have been recovered from the Agardhfjellet Formation on Svenskøya (Smith et al., 1976; Doyle \& Kelly, 1988; Ditchfield, 1997). According to Doyle \& Kelly (1988) the presence of Buchia tenuistriata in the same section suggests a Late Kimmeridgian age for the youngest sediments of the Agardhfjellet Formation in Kong Karls Land.

\section{Facies}

As in Spitsbergen, the Agardhfjellet Formation in Kong Karls Land was deposited in a distal marine inner-shelf environment within an epicontinental sea with oxic to offshore dysoxic to anoxic sea-floor conditions. 


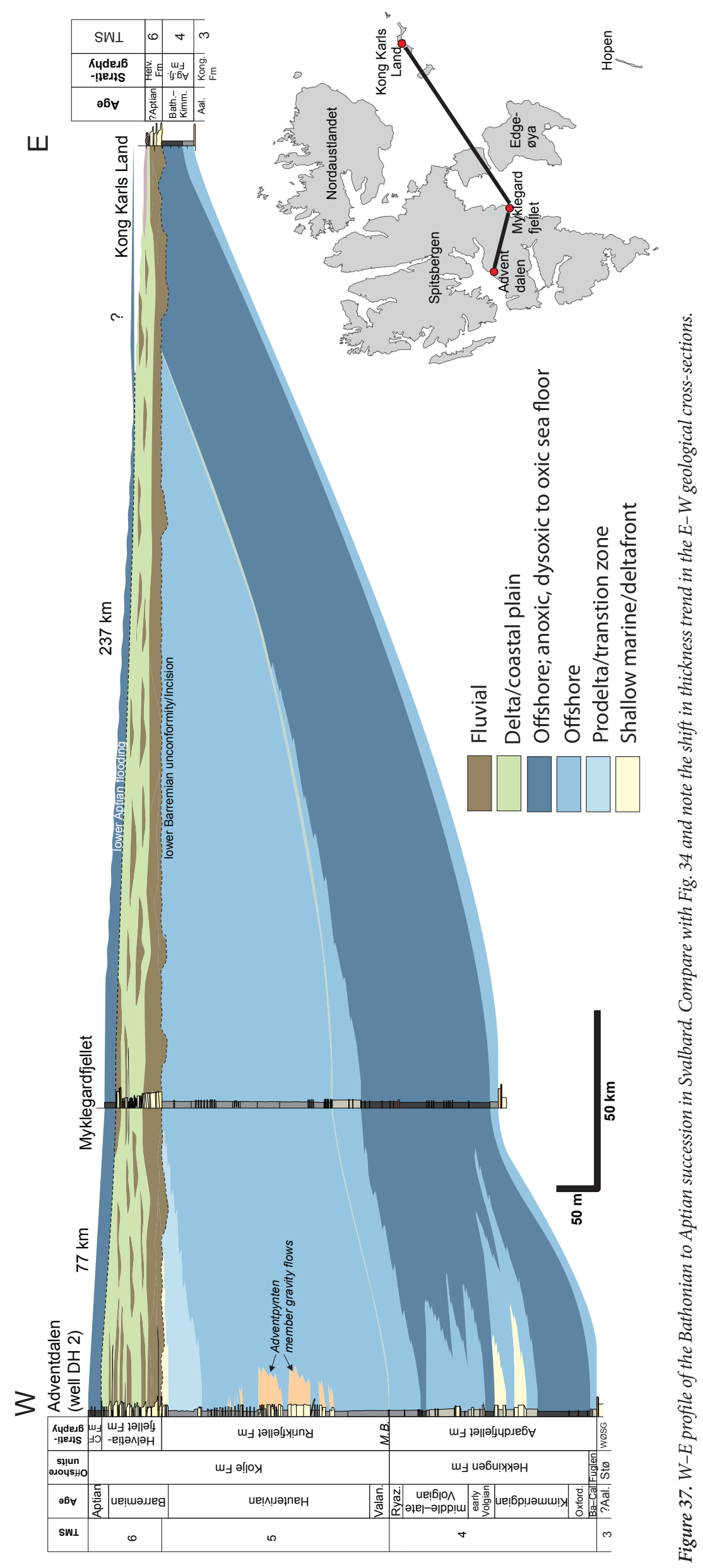


Sequence-stratigraphic expression of the surfaces In Spitsbergen and Kong Karls Land, the Agardhfjellet Formation is overlying Aalenian deposits. Between the Lower Aalenian deposits of the uppermost Wilhelmøya Subgroup and the base of the Agardhfjellet Formation there is a severe hiatus with missing Upper Aalenian and Bajocian strata (Smelror, 1994; Smelror et al., 2009; Mørk et al., 1999). In Spitsbergen, the boundary between the underlying Wilhelmøya Subgroup and the Agardhfjellet Formation is marked by a phosphate quartz conglomerate, the Brentskardhaugen Bed, of Bathonian age (Bäckstrøm \& Nagy, 1985). In some localities on Spitsbergen, the Brentskardhaugen Bed is conformably overlain by an Upper Bathonian glauconitic, chamositic carbonate and carbonate-cemented sandstone which is referred to as the Marhøgda Bed (Bäckstrøm \& Nagy, 1985). This unit when present has recently been assigned to the base of the Agardhfjellet Formation in Spitsbergen (Rismyhr et al., 2019; Koevoets et al., 2019). The Brentskardhaugen Bed is not observed in Kong Karls Land. The upper surface of the Kongsøya Formation is sharp and brecciated and overlain by a $0.3 \mathrm{~cm}$-thick unit of interbedded marine siltstone and massive red calcareous sandstone. Apart from lacking the characteristic chasmosite ooids the unit resembles the Marhøgda Bed in Spitsbergen. The sequence boundary of TMS 4 is placed with the same reasoning as in Spitsbergen at the surface between the marine, red, calcareous siltstone and the breccia of the Kongsøya Formation. The brecciated carbonate is probably a response of freshwater dissolution and suggests a subaerial unconformity.

The near 250 m-thick Bathonian to Ryazanian Agardhfjellet Formation in western Central Spitsbergen has been subdivided into six TR sequences (Koevoets et al., 2019). The succession in Kong Karls Land corresponds to the first TR sequence and the lower part of the second one in western central Spitsbergen i.e., which includes the Oppdalen and lower part of the Lardyfjellet members (Koevoets et al., 2016, 2019). The lack of well exposed outcrop of this succession with its recessively weathered character in Kong Karls Land gives great uncertainty to the subdivision into TR sequences. However, the wellexposed boundary between the silty Oppdalen Member and black paper shale of the Lardyfjellet Member is seen at some localities in Kong Karls Land. The boundary is suggested to be near the sequence boundary between TR 1 and 2 in Central Spitsbergen as defined by Koevoets et al. (2019). This suggestion is also consistent with the biostratigraphy (Smelror et al., 2018). The boundary between the Oppdalen and Lardyfjellet members might also be near the well-known Boreal mid- Callovian unconformity (Jacquin et al., 1998).

\section{Offshore seismic expression of the sequence}

Immediately offshore Kong Karls Land, the Agardhfjellet Formation is seen only as a single reflector; seismic unit $\mathrm{E}$ (Fig. 7). There is no clear seismic image of the boundary. Farther offshore, seismic data indicate that TMS 4 occurs mainly in synclines, where it is thicker than observed in the Kong Karls Land exposures. This suggests that organic-rich units are thicker in the lows, as is also commonly seen in the Barents Sea basins (Rønnevik \& Jacobsen; 1984, Anell et al., 2014c). Southeast of Kong Karls Land, high-amplitude reflections are observed within the TMS 4 sequence in the synclines, indicative of sill intrusions. Here, the thickness of the Agardhfjellet Formation decreases over the major anticlines. Intrusions have not been identified in the Jurassic section in seismic data from these anticlines. This relationship is similar to the one observed in the field in the Kongsøya anticline.

\section{Regional development and palaeogeography}

On the east coast of Spitsbergen, TMS 4 is $220 \mathrm{~m}$-thick (Dypvik et al., 1991a). The lower part of the Agardhfjellet Formation in Kong Karls Land shows clear similarities to other Svalbard localities and its offshore counterparts. The sequence starts with a pronounced stratigraphic break, generally followed by a thin remanie bed such as the Brentskardhaugen and Marhøgda beds on Spitsbergen.

In the Barents Sea, the Fuglen Formation correlates broadly with the Oppdalen Member in Svalbard, while the Upper Callovian to Upper Kimmeridgian Lardyfjellet Member in Svalbard correlates with the lowermost part of the offshore Hekkingen Formation, the Alge Member. The organic-rich Alge Member has up to 20\% TOC and an upper medium rich (2-6\% TOC) Krill Member, both showing kerogen type II and III (Henriksen et al., 2011). The high TOC in the Lardyfjellet Member in Kong Karls Land (up to $30 \%$, see Table 3) compares to similar high values in the offshore Alge Member.

The Hekkingen Formation belongs to the same global, high-organic, Late Jurassic to earliest Cretaceous production event. This event is highly correlative in the Arctic and the North Atlantic, and produced the main source rocks for most of the oil and gas fields in offshore Denmark, UK and Norway and in the West Siberian Basin (Spencer et al., 2008). Previous palaeogeographic reconstruction of the Agardhfjellet Formation suggested a coastline northwest of Svalbard (Smelror et al., 2009; Dypvik \& Zakharov, 2012). New data from the Agardhfjellet Formation in Central Western Spitsbergen suggests Late Kimmeridgian to Early Volgian shoreface or delta front deposits (Koevoets et al., 2019). This interpretation is consistent with the notion of a land area to the northwest of Spitsbergen. Fig. 33E shows a tentative palaeogeographic reconstruction of the Early Kimmeridgian in the northern Barents Sea and Svalbard.

\section{TMS 5, Valanginian to Hauterivian}

The Valanginian-Hauterivian section is eroded by the Helvetiafjellet Formation in Kong Karls Land and probably in several nearby offshore areas and except for one location this time period is marked by a hiatus 
in Kong Karls Land. During this period, reactivation of the Late Jurassic fold structures occurred (tectonic stage 5) and seismic mapping suggests deposition of a sequence preceding the Helvetiafjellet Formation which has onlapped onto some of the anticlines during tectonic stage 5 (Fig. 5A). During this stage accommodation space was created for the Hauterivian-Valanginian succession and the Barremian/Aptian Helvetiafjellet Formation in synclinal depressions. Erosion of the anticline at Kongsøya (Retziusfjellet) prior to deposition of the Helvetiafjellet Formation is supported by available biostratigraphic data, indicating that younger parts of the Agardhfjellet Formation were only observed southeast of Tordenskjoldberget, in a position downflank of the anticlinal crest (Fig. 5A). It is possible, but not clear from the seismic data in this area, that there was renewed tectonism in the Hauterivian/Barremian prior to the deposition of the Helvetiafjellet Formation. Due to lack of evidence of further subdivision, we have chosen to define tectonic stage 5 to refer to the whole of the Valanginian-Hauterivian time period.

The Early Cretaceous relief between the Kongsøya anticline and the Svenskøya syncline may have been in the order of $50 \mathrm{~m}$, taking into account the variation in thickness of the Helvetiafjellet Formation. This topography formed by tectonism and erosion was gradually infilled by the deposition of the Helvetiafjellet Formation.

In Spitsbergen, tectonic stage 5 is recorded by a major unconformity near the Late Hauterivian/Early Barremian boundary, i.e., Base Helvetiafjellet Formation. Uplift in the north was caused by increased influence of the tectonism related to the opening of the Amerasian Basin. The basin fill consisted of southward-prograding fluvial and deltaic systems. (Steel \& Worsley, 1984; Gjelberg \& Steel; 1995; Midtkandal \& Nystuen, 2009; Grundvåg et al., 2017).

The situation in the northern Barents Sea appears to be the same as in the Kong Karls Land outcrops (Fig. 5A): Palaeovalleys were formed by folding of the underlying Jurassic section and filled in by the Klippfisk and Knurr formations. In the southern Barents Sea, a coeval tectonic phase occurred between the deposition of the Knurr/ Klippfisk and Kolje formations and resulted in the reactivation of Late Jurassic extensional faults (Serck et al., 2017).

\section{Sequence stratigraphy of the Tordenskjoldberget Member and the Kolje Formation}

The $30 \mathrm{~m}$-thick Valanginian to Hauterivian Tordenskjoldberget Member of the Klippfisk Formation and the onshore equivalent of the Kolje Formation are assigned to the TMS 5. The Tordenskjoldberget Member was originally described by Smith et al. (1976), but later revised by Smelror et al. (1998).
Age

A Valanginian to Early Hauterivian age for the Tordenskjoldberget Member and a Hauterivian to Barremian age for the Kolje Formation equivalent is suggested (Smelror et al., 1998, 2018).

Facies

The condensed Tordenskjoldberget Member is assigned to the offshore Klippfisk Formation, which was deposited in an open well-oxygenated shelf environment with a very low sedimentation rate (Mørk et al., 1999).

Sequence-stratigraphic and seismic expression of the surfaces

As in the Barents Sea, the base of the Klippfisk Formation in Kong Karls Land is assigned to the well-known offshore seismic reflector informally called the Base Cretaceous Unconformity i.e., BCU (Faleide et al., 1993). This bed is interpreted as either reworked bentonites (Birkenmajer, 1980) or condensed marine deposits (Dypvik et al., 1992). A cored section from a drill-site in Adventdalen, Central Spitsbergen, shows well-preserved laminae of glauconite grains in the Myklegardfjellet Bed (Koevoets et al., 2019) and favours the interpretation of Dypvik et al. (1992).

In areas with no dolerite intrusions, the $\mathrm{BCU}$ reflector, here suggested to be the Base Tordenskjoldberget Member, is generated by a decrease in acoustic impedance and is displayed as a peak ('soft kick') in the seismic signal. The boundary between TMS 4 and 5 is not observed in this study in Kong Karls Land, but dating gives a considerable hiatus since the Volgian and Ryazanian are missing. The palynological samples yielded common reworked Jurassic dinoflagellate cysts (Smelror et al., 2018) which combined with the hiatus might suggest an erosive surface.

Due to carbonate and carbonate-cemented sandstone in the basal part of TMS 5, the correlative Klippfisk Formation gives a recognisable 'hard kick' in seismic sections.

\section{Regional development and palaeogeography}

In the earliest Cretaceous, the opening of the Amerasian Basin in the Arctic Ocean caused an uplift and gentle tilting in northern parts of the Barents-Kara region, with increased terrigenous supply from the north (Maher, 2001; Grantz et al., 2011). The areas of marine sedimentation were reduced, but an open marine connection was maintained into the Tethys Ocean in the south (Smelror et al., 1998). In the northernmost part of the region, near-shore marine environments existed at this time. Gradual uplift in the north gave less accommodation space offshore and erosion and condensation took place on basin-internal highs. The Klippfisk Formation was probably a result of this process as these condensed carbonate units are also found on structural highs on the Bjarmeland Platform and along 
the margin of the Nordkapp Basin to the south (Smelror et al., 1998; Bugge et al., 2002; Grundvåg et al., 2017). A pronounced unconformity occurs between lowermost Cretaceous dark shales and the overlying units of Lower Cretaceous (Valanginian to Lower Barremian) condensed carbonates and marls on these elevated areas. The condensed units also contain several major and minor stratigraphic gaps reflecting a complex interplay between local tectonic movements and eustatic sea-level changes during the Early Cretaceous.

The Tordenskjoldberget Member, sensu Smelror et al. (1998), is interpreted to represent a condensed shelf deposit equivalent to the Kutling Member of the Klippfisk Formation in the southwestern Barents Sea (Fig. 33F). On Spitsbergen, the Myklegardfjellet Bed is followed by Valanginian clay and silt deposits with minor carbonate that accumulated in shallow-marine to prodelta environments (i.e., the Wimanfjellet Member of the Rurikfjellet Formation). The prodelta environment is followed by an upward-shallowing trend due to the initial uplift of the areas to the north (Midtkandal \& Nystuen, 2009). This uplift is indicated by the southerly to southeasterly sediment transport direction measured in the cross-bedding of the Hauterivian Ullaberget Member on Spitsbergen (Gjelberg \& Steel, 1995; Midtkandal et al., 2008; Grundvåg et al. 2017; Grundvåg \& Olaussen, 2017). A newly discovered Lowermost Upper Hauterivian diamictite in central Spitsbergen with cobbles of delta or coastal plain deposits (Braathen et al., 2012, Grundvåg et al., 2017) is evidence of an older coarser-grained sandstone wedge prograding from the north caused by uplift in the north.

In the deeper parts and outer-shelf environments on the southwestern Barents Shelf (Hammerfest and Bjørnøya basins), thicker units of clay with thin limestone and dolomite layers were deposited (i.e., the Knurr and Kolje formations). Here, the sedimentation was more continuous than on the structural highs and platform areas, the clastic content was higher and carbonate beds were fewer. During this period point-sourced coarsegrained clastic wedges of Ryazanian to Valanginian age are banked against the margins of the Hammerfest Basin (Marin et al., 2017a).

\section{TMS 6, Barremian-Aptian}

The sixth major tectonic stage in Spitsbergen and Kong Karls Land is marked by a period of magmatic activity in the Barremian-Early Aptian, which was related to the development of the High Arctic Large Igneous Province (HALIP).

On the Kongsøya anticline, an occurrence of green volcanoclastic and arkosic arenites indicates a source from basalt lavas on the watershed of the Helvetiafjellet Formation. On Svenskøya, the Helvetiafjellet Formation passes upwards to finer-grained sandstones with fewer conglomerates, and in spite of a greater thickness with no sign of volcanoclastics. The Svenskøya section is therefore interpreted to pre-date volcanism and was deposited in incised valleys in structural depressions (synclines).

Aeromagnetic data, unpublished seismic data and outcrops show that Kong Karls Land is connected to a magmatic province in the northern Barents Sea, as reflected by massive sill intrusions into the Middle to Upper Jurassic shales (Figs. 1, 2 \& 31). Sill intrusions also occur in the underlying Triassic section. The sills are mainly layer-parallel, but cross-cutting relationships have also been observed. In the study area of Kong Karls Land, besides the extrusive volcanic rocks and the uppermost basalts on Kongsøya, basaltic magma was emplaced in two different settings;

1) as sills and intrusive bodies within the shale of the Agardhfjellet Formation (e.g., Kapp Altmann on Kongsøya and below Kükenthalfjellet at Svenskøya). These dolerite intrusions appear to cover a large area in and around Kong Karls Land, but do not occur in structurally high areas where the Upper Jurassic shale is thin or absent. They commonly display columnar jointing and are locally associated with mounds of altered, brick-red shale (Smith et al., 1976). The mounds lie stratigraphically above the dolerites. They contain baked fossils and are interpreted as shale that was thermally altered by hot fluid. As discussed in the introduction, most of the synclinal central part of Kongsøya consists of dolerites, which seem to be intrusions in the Agardhfjellet Formation. An alternative interpretation of the Kapp Altman intrusion as a feeder dyke was presented by Smith et al. (1976) (see also Grogan et al., 2000). However, the intrusive sills are clearly contained in the Agardhfjellet Formation which was semi-horizontal before the Cenozoic reactivation of the fold structures on Kong Karls Land.

2) as sill intrusions, typically several metres thick, in the sandstones of the Helvetiafjellet Formation on Svenskøya (Fig. 4). The intrusive counterparts of the Kong Karls Land Flows in Spitsbergen constitute the Diabasodden Suite that occurs throughout the island and intrudes strata from the Precambrian to Barremian (Senger et al., 2014a; Dallmann, 1999), preferentially intruding mechanically weaker shaledominated units such as the Middle Triassic Botneheia Formation in central Spitsbergen (Senger et al., 2014a, b). They have an offshore counterpart in a large part of the eastern Barents Sea (Polteau et al., 2015). The basaltic geochemical composition is similar to that of other pan-arctic HALIP volcanic rocks (Senger et al., 2014a).

Petrographically, all the extrusive and intrusive rocks are similar, with phenocrysts of plagioclase, clinopyroxene 
and/or olivine. The matrix may also contain pigeonite, amphibole, ilmenite, magnetite, apatite and devitrified or altered glass. South, east and north of Kong Karls Land the offshore seismic data show high-amplitude reflectors interpreted as volcanic rocks in Triassic and older strata (Grogan et al., 2000; Minakov et al., 2012). South of Svenskøya, the seismic data indicates intrusion mainly into Upper Jurassic strata. However, in heavily intruded areas the shallow dolerites mask the deeper geology, so that deeper intrusions may not be recognised (Fig. 38).

Sills emplaced in shales of the Upper Jurassic Agardhfjellet Formation cover an area of between 15.000 and $20,000 \mathrm{~km}^{2}$ to the south and southeast of Kong Karls Land (Fig. 31). Erosional remnants of dolerites emplaced within the Lower Cretaceous Helvetiafjellet Formation are interpreted in an area of approximately $2000 \mathrm{~km}^{2}$ to the south and east of Kongsøya and Abeløya, where the sea floor is characterised by tabular bathymetric highs. This interpretation is based on the time isochore between the dolerite reflector and the interpreted Jurassic reflectors. In heavily intruded areas, these levels are difficult to distinguish (Fig. 7). It is possible to draw a southern boundary line for the area where dolerites are mapped within the Cretaceous section (Fig. 31). Based on this interpretation, Svenskøya is situated close to the outer limit of major igneous activity in the Cretaceous section, whereas Kongsøya is situated well within it.

The southwestern limit of the Cretaceous basalts could be an indication of the outer limit of where the
Helvetiafjellet Formation was predominantly fluvial (Fig. 31), since lava flows on land will not build far out into the sea. This distribution is in accordance with the map presented by Smelror et al. (2009). The sediments between the basalts in the upper part of the Helvetiafjellet Formation on Kongsøya consist mainly of dark shales of probable lacustrine origin with abundant tree trunks. It is thought that the palaeo-topography at this stage was determined by the magmatic events. Lava flows and pyroclastics modify the topography, and thick sills and intrusions create uplift and normal faults due to differences in compaction (Fig. 38).

The sudden influx of volcanoclastics in the lower part of the Helvetiafjellet Formation on and around Kongsøya (which is stratigraphically high because of the structural position) suggests that magmatism took place during the deposition of the Helvetiafjellet Formation. Biostratigraphy based on terrestrial palynomorphs gives a general indeterminate Early Cretaceous age (Smelror et al. 2018), while sequence-stratigraphic correlation with Spitsbergen limits the magmatism to the Late Hauterivian to Early Aptian. On Franz Josef Land, lavas and tuffs with interbedded thin sediments have been described in the Tranquil Suite (Hauterivian-Barremian) and alternating continental sediments and lavas in the Salisbury Suite (Aptian-Albian) (Dibner, 1998; Corfu et al., 2013). It is reasonable to link the observed intrusions and lavas on Kong Karls Land to the same short-lived magmatism as postulated by Corfu et al. (2013) in Franz Josef Land and Spitsbergen where ${ }_{206} \mathrm{~Pb} /{ }_{238} \mathrm{U}$ dating

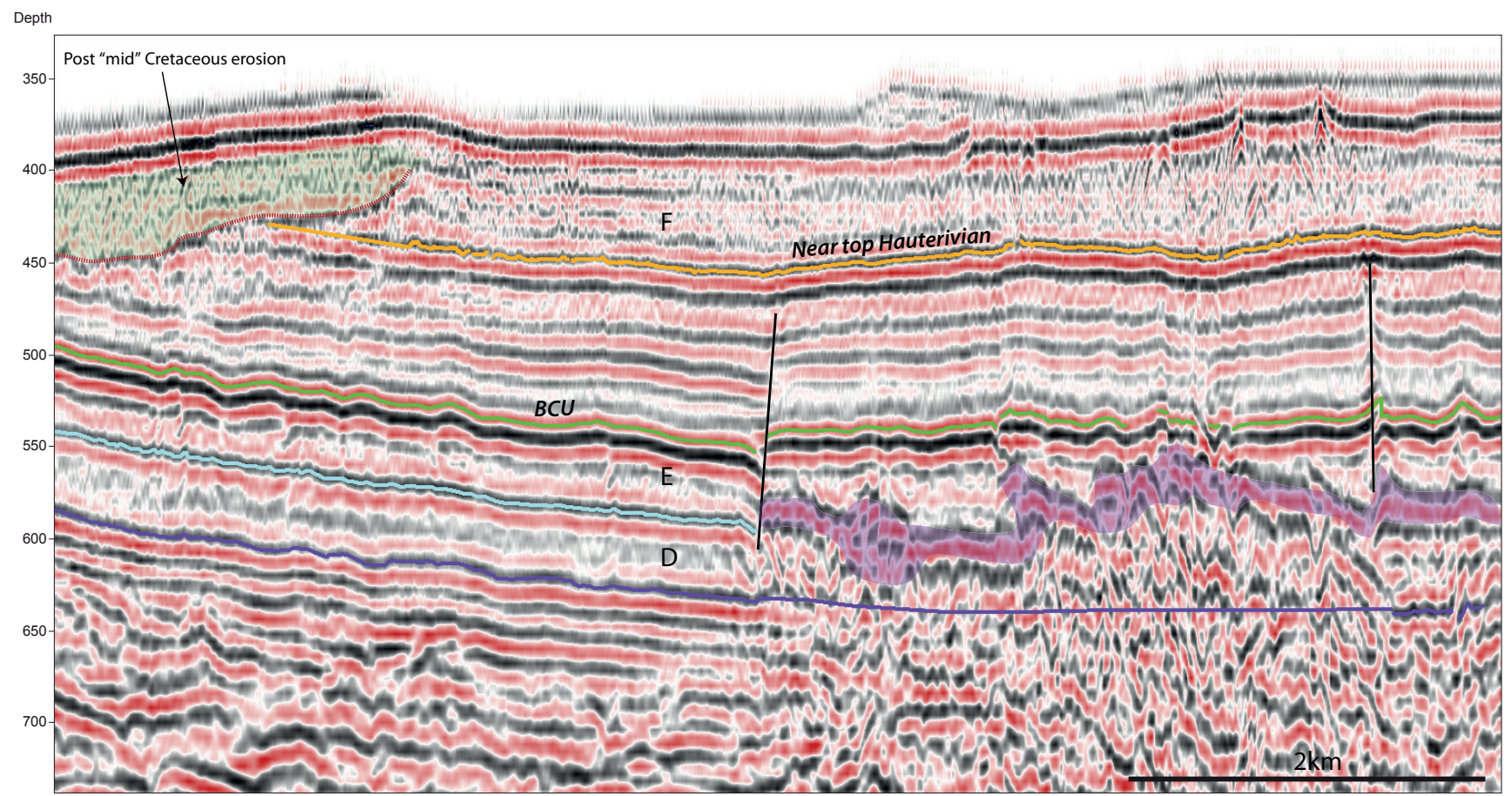

Figure 38. Seismic expression of sill intrusion in Upper Jurassic shale, seismic line 7825-90. The fault in the centre of the figure occurs at the boundary of the sill (transparent pink) and was probably formed as the sill intruded, thus forcing an uplift of the overlying sediments. Acoustic signals from below the sill are disturbed. For location of lines see Fig. 1. For seimic units see Fig. 7 and Table 2. 
limits the ages of sills to $122 \pm 1.1$ and $124,5 \pm 0.2 \mathrm{Ma}$, respectively. A bentonite penetrated in the Helvetiafjellet Formation in well DH 3 UNIS $\mathrm{CO}_{2} \mathrm{LAB}$ in Adventdalen, central Spitsbergen gave an age of $123.3 \pm 0.2 \mathrm{Ma}$ (Corfu et al., 2013). An Aptian age is therefore suggested for the Kong Karls Land Flows.

These radiometric datings are consistent with field observations and seismic interpretation which show that the magmatic activity in the HALIP post-dates the tectonic events which can be correlated with the orange reflector in Fig. 5A and preceded the Helvetiafjellet Formation.

Sequence stratigraphy of the Helvetiafjellet Formation and Kong Karls Land Flows

Only the lower part of TMS 6, i.e., the up to 70 m-thick Barremian to Aptian Helvetiafjellet Formation and Kong Karls Land Flows, is preserved in Kong Karls Land. In contrast, the Spitsbergen TMS 6 succession consists of the Helvetiafjellet Formation and the Aptian to Middle Albian Carolinefjellet Formation. TMS 6 is more than $850 \mathrm{~m}$-thick in southern Spitsbergen (Mørk et al., 1999).

\section{Age}

The Helvetiafjellet Formation in Spitsbergen is currently dated as Barremian to Early Aptian (Corfu et al., 2013; Midtkandal et al., 2016; Grundvåg et al., 2017). Associated tuff deposits within the middle part of the Helvetiafjellet Formation in Adventdalen, Central Spitsbergen, have given a U-Pb age of $123.3 \pm 0.2 \mathrm{Ma}$ (Corfu et al., 2013). The boundary between Barremian and Aptian is problematic (Midtkandal et al., 2016 \& Ogg pers. comm., 2018). Sparse recovered palynofloras suggest a near similar age or slightly younger age for the Helvetiafjellet Formation in Kong Karls Land (Smelror et al., 2018).

\section{Facies}

TMS 6 was deposited within a fluvial and alluvial plain overbank environment (Fig. 30). In places and within deep erosional scours, tidal dunes are observed at their base. In addition, plateau lavas and pyroclastic rocks intersect the continental deposits (Figs. 36 \& 37).

\section{Sequence-stratigraphic and seismic expression of the surfaces}

The base of the Helvetiafjellet Formation is not exposed where the Tordenskjoldberget Member is preserved. Elsewhere on Kong Karls Land, the absence of Upper Kimmeridgian to Hauterivian strata provides a considerable hiatus between the Helvetiafjellet Formation and the underlying Agardhfjellet Formation. The base of TMS 6 is marked by a sharp and erosive surface, and in some outcrops is observed to incise up to $10 \mathrm{~m}$ into the underlying offshore deposited Agardhfjellet Formation (Figs. 4, 27, 30 \& 37). The base of TMS 6 is as a subaerial erosional unconformity surface; key sequencestratigraphic surface 7. As on Spitsbergen the basal surface represents a major incision surface (e.g., Gjelberg \& Steel, 1995; Midtkandal \& Nystuen, 2009; Grundvåg \& Olaussen, 2017; Grundvåg et al., 2017). The incision is at a much larger scale in Kong Karls Land (Fig. 37), where both outcrop and nearby offshore seismic suggest it to have up to at least a hundred metres of relief.

Seismic data show that the thickness of seismic Unit $\mathrm{F}$ outside the basalt area varies from close to zero on the flanks of the anticlines to more than $100 \mathrm{~m}$ in the synclinal basins. Velocities in the order of 2200 to 2500 $\mathrm{m} / \mathrm{s}$ are predicted for this interval. The seismic character of the Helvetiafjellet Formation in the seismic data in the northern part of the offshore area (Fig. 5A) indicates sandy sections, which can be recognised for at least 100 $\mathrm{km}$ south of Kong Karls Land. Close to Kongsøya, the upper part of seismic unit $\mathrm{F}$ is commonly not preserved, due to post Lower Cretaceous erosion and especially Pliocene-Pleistocene glacial erosion.

\section{Regional development and palaeogeography}

On Spitsbergen, no major active tectonism is recorded in the Late Jurassic and Early Cretaceous, other than uplift in the north linked to the initiation of sea-floor spreading in the Amerasian Basin (Grantz et al., 2011; Spencer et al., 2011; Dörr et al., 2012; Senger et al., 2014b). The Helvetiafjellet Formation on Spitsbergen shows facies similarities to the Kong Karls Land outcrops. As on Kong Karls Land the basal part is interpreted as an incised valley, which is filled with either fluvial braided stream or tidal dunes (Gjelberg \& Steel, 1995; Midtkandal \& Nystuen, 2009). The formation shows more variable facies associations on Spitsbergen, comprising a mixture of fluvial braid-plain, delta-, coastal and alluvial plain deposits with thin coal seams, mouth bars, barrier islands and estuaries (Steel \& Worsley, 1984; Nemec, 1992; Gjelberg \& Steel, 1995; Midtkandal \& Nystuen, 2009; Grundvåg \& Olaussen, 2017; Grundvåg et al., 2017 and references therein). Dinosaur tracks, coal beds, kaolinitic seat earth, plant fragments and tree trunks (Nemec, 1992; Hurum et al., 2006, 2016; Smelror, 2008) are common features in the Helvetiafjellet Formation on Spitsbergen, suggesting a seasonal and periodic warm, humid climate. Kong Karls Land belongs to a tectonic province that includes large parts of the northern and eastern Barents Sea. Intraplate tectonism resulted in the uplift of the Sentralbanken and part of Gardarbanken highs. Deposition on Spitsbergen probably occurred contemporaneously with erosion/non-deposition on the anticlines in Kong Karls Land and volcanism (Fig. 30 \& 33G). In Middle Aptian-Albian times, a general transgression resulted in a retrograding coastline in Spitsbergen (Midtkandal et al., 2016; Grundvåg et al. 2017) and drowning of the Gardarbanken and Sentralbanken highs.

As a result, uplift and erosion in the northernmost Barents Shelf, and the northern and northwestern parts of Svalbard, Lower Cretaceous clinoforms in the 
Western Barents Sea show progradation in two dominant directions, one from northeast towards southwest and another from northwest towards southeast (Grundvåg et al., 2017; Marin et al., 2017b).

\section{The post-Aptian tectonism; folding, uplift and glaciation}

Kong Karls Land and the surrounding shelf areas have experienced several tectonic phases of subsidence and uplift since the Early Cretaceous. Plate-tectonic movements in the Atlantic Ocean in the Late Cretaceous and Palaeogene caused uplift of most of Svalbard (Dimakis et al., 1998). The Palaeogene breakup of the Eurasian Basin affected also the northern margin of Svalbard and the northern Barents Sea (Faleide et al., 2008). Kong Karls Land and the platform underwent compression with reactivation of fold structures. The major folding phase which created fold amplitudes of several hundred metres clearly post-dates the Late Jurassic and the Hauterivian/Barremian fold structures (Grogan et al., 2000). The seismic data show that this later folding has affected all preserved pre-Quaternary rocks in the region. No Mesozoic strata younger than the Early Cretaceous have been observed in the northern Barents Sea, nor in Svalbard (Smelror \& Larssen, 2016), so this last contractional phase cannot be dated stratigraphically. Based on the regional tectonic setting, a Late Cretaceous age is possible, although a Palaeogene age is considered to be more likely (Grogan et al., 1999).

Pliocene and Quaternary vertical movement Cycles of Cenozoic burial, tectonism, uplift and subsequent erosion, and rapid glacial erosion in the
Quaternary, caused erosion deeply into the Mesozoic rocks on Kong Karls Land and in the northern Barents Sea (Faleide et al., 1996). Kong Karls Land has the highest recognized Holocene raised beaches in Svalbard (Salvigsen, 1981; Ingolfsson et al., 1995; Forman et al., 2004). The marine limit is recognised at 100-110 m above MSL on Kongsøya and at approximately $120 \mathrm{~m}$ on Svenskøya (Salvigsen, 1981). These strandlines are responses to the last glacial event. By combining values for eustatic sea-level rise and relative sea-level changes since 11-12 ka BP, 150-200 m of isostatic uplift can be estimated for Kong Karls Land since the last deglaciation (Ingolfsson, pers. comm., 2015).

\section{Maximum burial of the Mesozoic succession in Kong} Karls Land

The last denudation phase took place in the Quaternary related to rapid erosion throughout several glacial cycles during the last 2.7 Ma (Elverhøi et al., 1998). The remains of Late Barremian to Aptian sediments on Kong Karls Land are incised by Quaternary to recent glacial erosion, with gravel and sand infill. Vitrinite reflectivity data from Upper Jurassic mudstone (mud) show values of 0.35 and 0.40. Combined with $\operatorname{Tmax}$ values of $415^{\circ} \mathrm{C}$ and $426^{\circ} \mathrm{C}$, this shows that apart from rock baked by sills, all potential hydrocarbon source rock units are immature (Table 3). This is consistent with the fact that only carbonates or carbonate-cemented sandstones and baked sediments are well-consolidated sedimentary rocks in Kong Karls Land. The Rock Eval and vitrinite data combined with no or minor quartz overgrowth, and woody material with preserved open cell structures, imply that the Kong Karls Land strata have not experienced temperatures above $50 / 60^{\circ} \mathrm{C}$. Palaeogene to Neogene modelled erosion in Kong Karls Land and Kong Karl Platform is averaged to $2 \mathrm{~km}$ (Amantov \& Fjeldskaar, 2017). Adding approximate $200 \mathrm{~m}$ of Quaternary erosion (Fjeldskaar \& Amantov,

Table 3. Geochemical analyses; Rock Eval and vitrinite analysis of samples from the upper part of the Lardyfjellet Member on Kükenthalfjellet, Svenskøya and Tordenskjoldberget/Passet, Kongsøya. The accuracy of such low vitrinte values are problematic, but the corresponding low Tmax values are consistent with an immature potential source rock and corresponding maximum previous burial.

\begin{tabular}{|c|c|c|c|c|c|c|c|c|c|}
\hline Sample & Location & & $T \max$ & $S 1 \mathrm{~kg} / \mathrm{t}$ & $S 2 \mathrm{~kg} / \mathrm{t}$ & ТОС\% & $P I$ & $H I$ & $\% V R$ \\
\hline KPL 16 & Kükenthalfjellet & & 418 & 1,15 & 24,74 & 12,3 & 0,04 & 200 & 0,30 \\
\hline KPL 17 & Kükenthalfjellet & & 415 & 0,23 & 6,49 & 6,1 & 0,03 & 106 & ndp \\
\hline \multirow[t]{2}{*}{ KPL 18} & Kükenthalfjellet & & 417 & 0,61 & 14,31 & 8,5 & 0,04 & 168 & ndp \\
\hline & & $\begin{array}{l}\text { Vertical distance from base } \\
\text { of a } 10 \mathrm{~m} \text { thick sill, intruding } \\
\text { the Lardyfjellet Member }\end{array}$ & & & & & & & \\
\hline TB 3 & Passet/Tordenskjoldberget & $+7 \mathrm{~m}$ & ndp & ndp & ndp & ndp & ndp & ndp & 0,38 \\
\hline TB 4 & Passet/Tordenskjoldberget & $7 \mathrm{~m}$ & 407 & 3,39 & 70,56 & 24,2 & 0,05 & 291 & 0,42 \\
\hline TB 5 & Passet/Tordenskjoldberget & $6 \mathrm{~m}$ & 410 & 6,17 & 106,89 & 30,1 & 0,05 & 355 & 0,38 \\
\hline TB 6 & Passet/Tordenskjoldberget & $5 \mathrm{~m}$ & 442 & 0,03 & 1,08 & 1,3 & 0,03 & 85 & 0,83 \\
\hline TB 7 & Passet/Tordenskjoldberget & $4 \mathrm{~m}$ & 591 & 0,15 & 1,35 & 24,2 & 0,1 & 6 & 2,18 \\
\hline
\end{tabular}




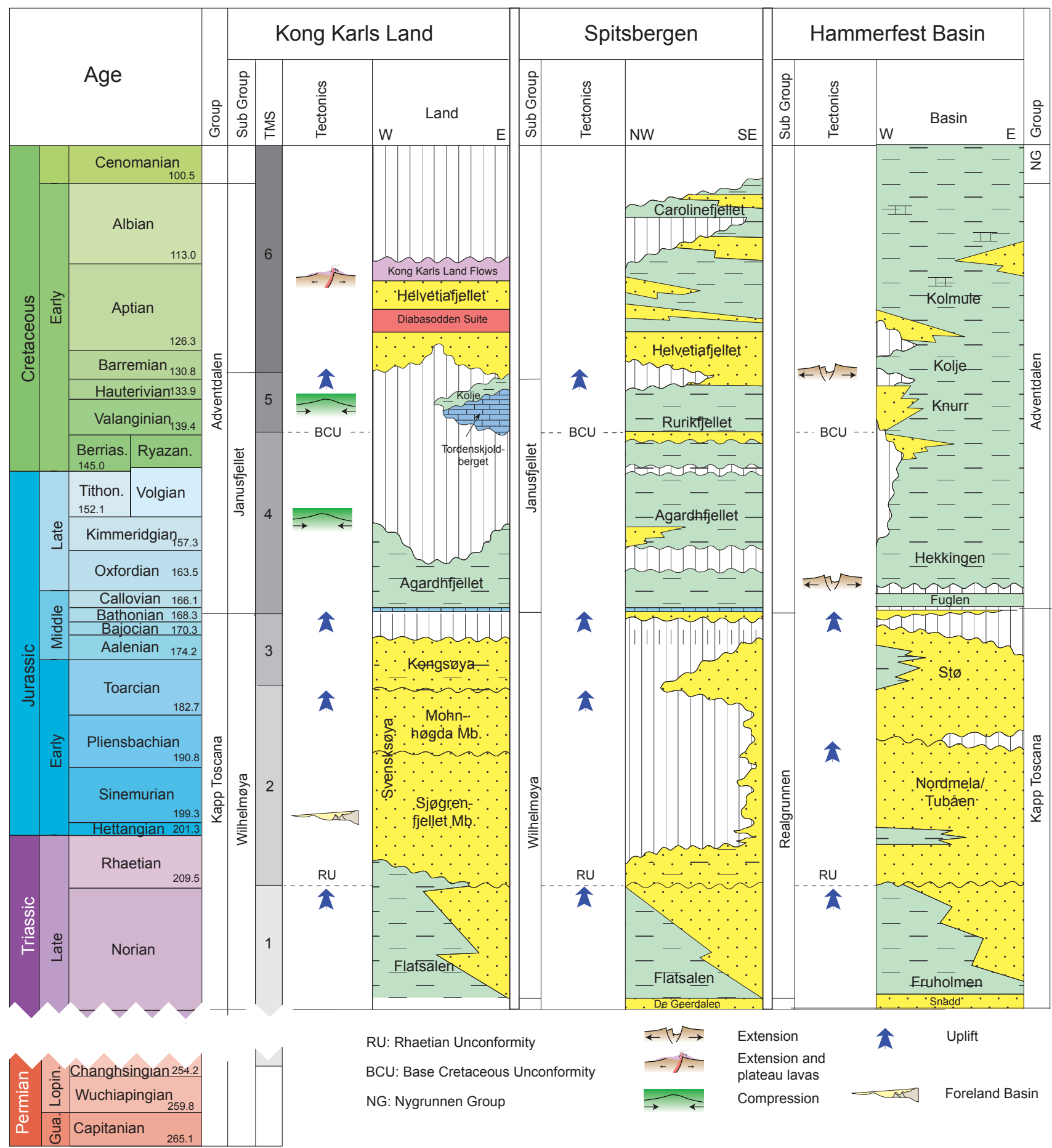

Figure 39. Summary of the stratigraphy, sequences and tectonics between Kong Karls Land, Spitsbergen and the Hammerfest Basin in the southwestern Barents Sea.

2017) a maximal burial of 2 to $2.5 \mathrm{~km}$ is suggested. Given a normal temperature gradient of $30 / 35^{\circ} \mathrm{C}$ per $\mathrm{km}$, this estimation is in line with obtained vitrinite and Tmax values (Table 3). However, the temperature gradient of the basin may have periodically been higher during the Early Cretaceous volcanism. The influence of sills can also be recorded by Tmax and vitrinite measurements. Close to a $10 \mathrm{~m}$-thick sill in the Passet/Tordenskjoldberget locality, Tmax shows a horizontal increase towards the sill from
$407 / 412^{\circ} \mathrm{C}$ to $442 / 591^{\circ} \mathrm{C}$ (Table 3). Vitrinite measurements above this sill reflect a similar trend from $0.38 / 0.42 \%$ to 0.83 and finally $2.18 \%$. Increasing maturation is only observed within $5 \mathrm{~m}$ from the sill. Similar trends of local heating of Middle Triassic organic-rich mudstones from Early Cretaceous sill emplacements are also reported from Edgeøya (Brekke et al., 2014) and from heterolithic Upper Triassic sandstone shale facies in central part of Spitsbergen (Senger et al., 2013). 


\section{Summary and conclusions}

The 300 m-thick, mostly unconsolidated, Upper Triassic to Lower Cretaceous succession in the Kong Karls Land archipelago provides essential data for establishing an improved understanding of the Mesozoic basin evolution particularly in the northern Barents Sea, but also for the Southwest Barents Sea. Fig. 39 shows the stratigraphic link between Kong Karls Land, Spitsbergen and the Hammerfest Basin.

The onshore-offshore link is also clearly demonstrated by regional 2D seismic lines where key sequencestratigraphic surfaces defined onshore can be followed as seismic stratigraphic surfaces on nearby offshore seismic lines due to the impedance contrasts (Fig. 7).

- The six tectonic megasequences (TMS 1 to 6) defined herein span the period from near top Permian to near top Albian (top Aptian in Kong Karls Land). They are correlative, although not necessary chronostratigraphic, throughout Svalbard and in the greater Barents Sea. Some of them can be recognised also in East and North Greenland, the Norwegian Sea and the Sverdrup Basin.

- In the eastern Barents Sea and eastern part of Svalbard, the near top Permian to near Base Rhaetian succession, TMS 1 , is characterised by a northwestward prograding shoreline which gradually becomes aggrading and finally transgressed by the Norian pan-Arctic widespread flooding. The lowest exposed unit in Kong Karls Land represents the Norian part of TMS 1. Combined with outcrops on Hopen this lower hierarchy sequence is defined as a transgressiveregressive sequence with a thin transgressive system tract, i.e., the Norian pan-Arctic flooding at the base followed by a thicker regressive system tract shallowing upward to shoreface or delta-front deposits.

- TMS 2 includes the Svenskøya Formation and is dated from near Base Rhaetian to Early Toarcian. The base of TMS 2 is one of the major sequence-stratigraphic boundary surfaces of the Mesozoic strata in the Arctic and herein called the Rhaetian unconformity. It marks a large global plate-tectonic reconstruction, the Early Cimmerian phase, and in the Barents Sea it is linked to the movement of the Novaya Zemlya Fold -and-Thrust belt. TMS 2 is further subdivided into two lower-order sequences, a lower near $150 \mathrm{~m}$-thick aggrading coastal plain to estuarine deposit, the Rhaetian to Lower Pliensbachian Sjøgrenfjellet Member, and an upper near $50 \mathrm{~m}$-thick shoreline to offshore deposit, the Late Pliensbachian to Lower Toarcian Mohnhøgda Member. The middle and upper parts of the Sjøgrenfjellet Member show similarities to the offshore Nordmela Formation whereas the Mohnhøgda Member is comparable to the prolific oil and gas reservoir unit in the Barents Sea; the lower part of the Stø Formation. We speculate if the much thicker TMS 2 in Kong Karls Land, in contrast to the thin condensed unit with several hiatuses in Spitsbergen is linked as a distal response to the development of the North Barents Basin in the east, i.e., the Novaya Zemlya Fold-andThrust Belt tectonics. The provenance area for the Flatsalen and Svenskøya formations is debatable, but we suggest that sediments are sourced from continental areas located N-NE of Svalbard, as well as from the east. The Kongsøya Formation, correlated with strata on the eastern coast of Spitsbergen, suggests a shift in drainage area with a provenance from the northwest.

- TMS 3, the Kongsøya Formation, was deposited during Late Toarcian to Early Aalenian times. It culminates the sandstone-prone lithology in the lower Middle Jurassic, with deposition of a marine and highly condensed, up to $40 \mathrm{~m}$-thick succession of mudstones, sandstones and minor carbonates. During deposition of TMS 3, the east-west thickness difference, as seen in the Norian to Early Pliensbachian, diminished, suggesting a slowing down of subsidence. At this time, Svalbard was likely still slightly tilted towards the south, with periodic subaerial exposure. By Early Aalenian time, thin condensed units were deposited throughout Svalbard, reflecting erosion and reworking of previous strata, including incision and development of large hiatuses. Platform areas in the Barents Sea are also characterised by uplift, erosion and condensation, with several hiatuses. The uplift is likely related to a larger reorganisation of the northwestern corner of the Barents Sea Shelf.

- The Bathonian to Aptian succession, comprising the upper three tectonic megasequences, TMS 4-6, has only thin remnants exposed in Kong Karls Land.

i) the Bathonian to near Ryazanian-Valanginian boundary, TMS 4, corresponds to the Agardhfjellet Formation, but only the lowermost part is preserved in Kong Karls Land.

ii) the thin Valanginian to Hauterivian, TMS 5, is time-equivalent to the Rurikfjellet Formation onshore and equivalent to the Knurr and Kolje formations offshore.

iii) the Barremian to Albian units, TMS 6, include the Helvetiafjellet and Carolinefjellet formations in Spitsbergen. Extrusive volcanic rocks of the High Arctic Large Igneous Province (HALIP) and the clastic Helvetiafjellet Formation are the uppermost preserved units of this megasequence observed in Kong Karls Land.

- TMS 4-6 coincides with major rift phases in the North Atlantic and the southwestern Barents Sea, leading to the formation of deeper basins flanked by exposed platforms and structural highs. The southwestern Barents Sea experienced intensified tectonism, which is particularly well expressed during Middle Jurassic 
to Early Cretaceous time in the northern part of the NE Atlantic rift. In contrast, the northern and eastern Barents Sea, including Kong Karls Land experienced deposition on large epicontinental platforms in a regime of tectonic contraction and later uplift and volcanism related to the HALIP. This is well demonstrated by the up to $70 \mathrm{~m}$-thick mudstone with minor carbonates that dominated Bathonian to Hauterivian, TMS 3 and 4, in Kong Karls Land, which reaches a thickness of more than $500 \mathrm{~m}$ in Spitsbergen. The thickness of the Bathonian-Kimmeridgian section on Kong Karls Land varies according to the structural position, and the upper Agardhfjellet Formation is only present in structural lows. This variation is also seen on seismic sections in the northern Barents Sea, and indicates regional tectonic movements with low amplitudes.

- The boundary between TMS 4 and 5 corresponds to the Base Cretaceous Unconformity (BCU) on the Norwegian Continental Shelf and on Spitsbergen. Locally in Kong Karls Land, TMS 4 is capped by a thin Valanginian sandy limestone/calcareous sandstone named the Tordenskjoldberget Member. This unit is interpreted to represent condensed shelf deposition and is assigned to the Kutling Member of the Klippfisk Formation in the southern Barents Sea. In most Kong Karls Land exposures, the boundary of TMS 6 is developed as a well-defined unconformity where fluvial or estuarine channels of the Upper Hauterivian/ Barremian Helvetiafjellet Formation erode into the offshore marine mudstones of the Oxfordian to Late Kimmeridgian Agardhfjellet Formation. A reactivation of the Late Jurassic compression took place prior to the deposition of the Helvetiafjellet Formation in Kong Karls Land and the northern Barents Sea. The Helvetiafjellet Formation on Kong Karls Land is represented by channellised facies and alluvial to coastal plain deposits with thin coaly units. The 10 $\mathrm{m}$ to $60 \mathrm{~m}$-thick Helvetiafjellet Formation exposures show an abrupt influx of volcanoclastics overlain and interbedded with tholeiitic basalt lavas. This volcanism is related to the HALIP and the opening Amerasian Basin, which resulted in uplift of the northern Barents Shelf and southward tilting of the Svalbard Platform. The braided rivers or fluvial channel belts follow the axes of the synclines and show drainage from the northeast.

- Low vitrinite and lack of quartz cementation shows that the uplifted exposures on Kong Karls Land are a result of a relatively shallow maximum burial depth of 2-2.5 km. Extensive Pliocene and Pleistocene periods of erosion were hindered by Lower Cretaceous plateau lavas and sills which cap the islands.

- The data from Kong Karls Land are important for improving our understanding of the regional development during the latest Triassic to Early Cretaceous in the northern Barents Sea and for evaluation of the petroleum potential/resources of the northern Barents Sea. The succession shows excellent source and reservoir rock potential.

Acknowledgements. The present paper is based on fieldwork during expeditions to Kong Karls Land arranged by Statoil in 1984 and the Norwegian Petroleum Directorate in 1992, and on previously unpublished data documented by Larssen et al. $(1995,2008)$. Geologists participating in these expeditions are acknowledged for contributing to the observations and geological sampling. The present interpretations and conclusions, however, rest solely on the authors. The current work is also part of the Eni Norge Fasena project, the University in Stavanger and UNIS lead industry sponsored project LoCrA (Lower Cretaceous Arctic basin fill), the ARCEx project (Research Centre for Arctic Petroleum Exploration) funded by the Research Council of Norway (grant number 228107) and the Triassic North project under grant 234152 from the Research Council of Norway (RCN). We also thank Atle Mørk for constructive comments on an early draft of the manuscript. Winfried Dallmann and Tony Doré are gratefully acknowledged for help to improve the clarity of the manuscript. Anna Glowacka is thanked for drawing some of the figures. Especially we will thank Geir Samue lsen, Lundin Norway AS, for his patience and help with correction of some of the figures.

\section{References}

Allen, J.R.L. 1983: Studies in fluviatile sedimentation: bars, barcomplexes and sandstone sheets (low sinuosity braided streams) in the Brownstones (Lower Devonian), Welsh Borders. Sedimentary Geology 33, 237-293.

https://doi.org/10.1016/0037-0738(83)90076-3.

Amantov, A. \& Fjeldskaar, W. 2017: Meso-Cenozoic exhumation and relevant isostatic process : Barents and Kara Shelf. Journal Geodynamics 118, 118-139.

https://doi.org/10.1016/j.jog.2017.12.001.

Anell, I., Braathen, A. \& Olaussen, S. 2014a: The Triassic - Early Jurassic of the northern Barents Shelf: a regional understanding of the Longyearbyen $\mathrm{CO}_{2}$ reservoir. Norwegian Journal of Geology 94, 83-98.

Anell, I., Midtkandal, I. \& Braathen, A. 2014b: Trajectory analysis and inferences on geometric relationships of an Early Triassic prograding clinoform succession on the northern Barents Shelf. Marine and Petroleum Geology 54, 67-179.

https://doi.org/10.1016/j.marpetgeo.2014.03.005.

Anell, I., Braathen, A. \& Olaussen, S. 2014c: Regional constraints of the Sørkapp Basin: A Carboniferous relic or a Cretaceous depression. Marine and Petroleum Geology 54, 123-138.

https://doi.org/10.1016/j.marpetgeo.2014.02.023.

Anell, I., Faleide, J.I. \& Braathen, A. 2016: Regional tectonosedimentary development of the highs and basins of the northwest Barents Shelf. Norwegian Journal of Geology 96, 27-41.

Ashchoff, J.L., Olariu, C. \& Steel, R.J. 2017: Recognition and significance of bayhead delta deposits in the rock record: A comparison of modern and ancient systems. Sedimentology 65, 62-95. https://doi.org/10.1111/sed.12351.

Ashley, G.M. 1990: Classification of large-scale subaqueous bedforms: a new look at an old problem. Journal of Sedimentary Petrology 60, 160-172. https://doi.org/10.2110/jsr.60.160.

Bailey, J.C. \& Rasmussen, M.H. 1997: Petrochemistry of Jurassic and Cretaceous tholeiites from Kong Karls Land, Svalbard, and their relation to Mesozoic magmatism in the Arctic. Polar Research 16, 37-62. https://doi.org/10.3402/polar.v16i1.6624. 
Berglund, L., Augustson, J., Færseth, R., Gjelberg, J. \& Ramberg-Moe, H. 1986: The evolution of the Hammerfest basin. In Spencer, A. (ed.): Habitat of Hydrocarbons on the Norwegian Continental Shelf, Graham \& Trotman, London, pp. 319-338.

Bhattacharya, J. \& Walker, R.G. 1992: Deltas. In Walker, R.G. \& James, N.R. (eds.): Facies Models: Response to Sea Level Change, Geological Association of Canada, pp. 157-177.

Birkenmajer, K. 1980: Jurassic - Lower Cretaceous succession at Agardhbukta, East Spitsbergen. Studia Geologica Polonica 66, 35-52.

Bjærke, T. 1977: Mesozoic palynology of Svalbard II. Palynomorphs from the Mesozoic sequence of Kong Karls Land. Norsk Polarinstitutt Årbok 1976, 83-120.

Braathen, A., Bælum, K., Christensen, H.H., Dahl, T., Eiken, O., Elvebakk, H., Hansen, F., Hanssen, T.H., Jochmann, M., Lie, T., Johansen, T.A., Johnsen, H., Larsen, L., Mertes, J., Mørk, A., Mørk, M.B., Nemec, W., Olaussen, S., Oye, V., Røed, K., Titlestad, O., Tveranger, J. \& Vagle, K. 2012: Longyearbyen $\mathrm{CO}_{2}$ Lab of Svalbard, Norway - first assessment of the sedimentary succession for $\mathrm{CO}_{2}$ storage. Norwegian Journal of Geology 92, 353-376.

Brekke, T., Krajewski, K.P. \& Hubred, J.H. 2014: Organic geochemistry and petrography of thermally altered sections of the Middle Triassic Botneheia Formation on south-western Edgeøya, Svalbard. Norwegian Petroleum Directorate Bulletin 11,111-128.

Buchan, K.L. \& Ernst, R., 2006: Giant dyke swarms and the reconstruction of the Canadian Arctic islands, Greenland, Svalbard and Franz Josef Land. In Hanski, E., Mertanen, S., Rämö, T. \& Vuollo, J. (eds.): Dyke Swarms: Time Markers of Crustal Evolution, Taylor \& Francis, London, pp. 27-48.

Bue, E.P. \& Andresen, A. 2013: Constraining depositional models in the Barents Sea region using detrital zircon $\mathrm{U}-\mathrm{Pb}$ data from Mesozoic sediments in Svalbard. Geological Society of London, Special Publications 386, 261-279.

Bugge, T., Elvebakk, G., Fanavoll., Mangerud, G., Smelror, M., Weiss, H., Gjelberg, J., Kristensen, S.E. \& Nilsen, K. 2002: Shallow stratigraphic drilling applied in hydrocarbon exploration of the Nordkapp Basin, Barents Sea. Marine and Petroleum Geology 19, 13-37. https://doi.org/10.1016/S0264-8172(01)00051-4.

Buiter, S.J.H. \& Torsvik T.H. 2007: Horizontal movements in the eastern Barents Sea constrained by numerical models and plate reconstructions. Geophysical Journal International 137, 1376-1389. https://doi.org/10.1111/j.1365-246X.2007.03595.x.

Bäckström, S.A. \& Nagy, J. 1985: Depositional history and fauna of a Jurassic phosphorite conglomerate (the Brentskardhaugen Bed) in Spitsbergen. Norsk Polarinstitutt Skrifter 183, 1-61.

Cheel, R.J. 1991: Grain Fabric in Hummocky Cross-Stratified Storm Beds: Genetic Implications. Journal of Sedimentary Research 61, 102-110.

https://doi.org/10.1306/D426769A-2B26-11D7-8648000102C1865D.

Clifton, H.E. 2006: A reexamination of facies models for clastic shorelines. In Posamentier, H.W. \& Walker, R.G. (eds.): Facies models revisited, Society for Sedimentary Geology, Special Publication, Tulsa, pp. 293-338.

Corfu, F., Polteau, S., Planke, S., Faleide, J.I., Svensen, H., Zayoncheck, A. \& Stolbov, N. 2013: U-Pb geochronology of Cretaceous magmatism on Svalbard and Franz Josef Land, Barents Sea Large Igneous Province. Geological Magazine 150, 1127-1135. https://doi.org/10.1017/S0016756813000162.

Cross, T.A. 1986: Tectonic controls of foreland basin subsidence and Laramide style deformation, western United States. In Allen, P. \& Homewood, P. (eds.): Foreland basins, International Association of Sedimentologists Special Publication 8, pp. 15-39. https://doi.org/10.1002/9781444303810.ch1.

Dallmann, W.K. 1999: Lithostratigraphic Lexicon of Svalbard, Upper Palaeozoic to Quaternary bedrock, Review and recommendations for nomenclature use. Norwegian Polar Institute, Tromsø, 318 pp.
Dalrymple, R.W. \& Choi, K. 2007: Morphologic and facies trends through the fluvial-marine transition in tide-dominated depositional systems: a schematic framework for environmental and sequence-stratigraphic interpretation. Earth-Science Reviews 81, 135-174. https://doi.org/10.1016/j.earscirev.2006.10.002.

Dalrymple, R.W., Zaitlin, B.A. \& Boyd, R. 1992: Estuarine facies models; conceptual basis and stratigraphic implications. Journal of Sedimentary Research 62, 1130-1146.

https://doi.org/10.1306/D4267A69-2B26-11D7-8648000102C1865D.

Davis R.A. 2012: Tidal Signatures and Their Preservation Potential in Stratigraphic Sequences. In Davis, Jr.R. \& Dalrymple, R. (eds): Principles of Tidal Sedimentology, Springer, Dordrecht, pp. 35-55. https://doi.org/10.1007/978-94-007-0123-6_3.

DeCelles, P.G. \& Giles, K.A. 1996: Foreland basin systems. Basin Research 8, 105-123. https://doi.org/10.1046/j.1365-2117.1996.01491.x.

Diebner, V.D. 1998: The geology of Franz Josef Land. Norsk Polarinstitutt Meddelelser 146, 109-137.

Dimakis, P., Braathen, B.I., Faleide, J.I., Elverhøi, A. \& Gudlaugsson, S.T. 1998: Cenozoic erosion and the preglacial uplift of the SvalbardBarents Sea region. Tectonophysics 300, 311-327. https://doi.org/10.1016/S0040-1951(98)00245-5.

Ditchfield, P.W. 1997: High northern palaeolatitude JurassicCretaceous palaeotemperature variation: new data from Kong Karls Land, Svalbard. Palaeogeography. Palaeoclimatology. Palaeoecology 130, 163-175. https://doi.org/10.1016/S0031-0182(96)00054-5.

Doyle, P. 1987: Systematic status of Pseudohibolites Blüthgen 1936 (Belemnitida, Coleoidea) from Kong Karls Land, Svalbard. Geological Magazine 124, 165-166. https://doi.org/10.1017/S0016756800015983.

Doyle, P. \& Kelly, S.R.A. 1988: The Jurassic and Cretaceous belemnites of Kong Karls Land, Svalbard. Norsk Polarinstitutt Skrifter 189, $1-77$.

Drachev S.S. 2016: Fold belts and sedimentary basins of the Eurasian Arctic. Arktos 2, 21. https://doi.org/10.1007/s41063-015-0014-8.

Drachev S.S., Malyshev N. \& Nikishin A. 2010: Tectonic history and petroleum geology of the Russian Arctic Shelves: an overview. In Vining B.A. \& Pickering S.C. (eds): Petroleum Geology: From Mature Basins to New Frontiers - Proceedings of the $7^{\text {th }}$ Petroleum Geology Conference, Geological Society of London, pp. 591-619. https://doi.org/10.1144/0070591.

Dumas, S. \& Arnott, R. 2006: Origin of hummocky and swaley crossstratification-the controlling influence of unidirectional current strength and aggradation rate. Geology 34, 1073-1076. https://doi.org/10.1130/G22930A.1.

Dumas, S., Arnott, R.W.C. \& Southard, J.B. 2005: Experiments on oscillatory-flow and combined-flow bed forms: implications for interpreting parts of the shallow-marine sedimentary record. Journal of Sedimentary Research 75, 501-513. https://doi.org/10.2110/jsr.2005.039.

Dypvik, H. \& Zakharov, V. 2012: Late Jurassic-Early Cretaceous finegrained epicontinental arctic sedimentation-mineralogy and geochemistry of shales from the Late Jurassic-Early Cretaceous transition. Norwegian Journal Geology 92, 65-87.

Dypvik, H., Nagy, J., Eikeland, T.A., Backer-Owe, K. \& Johansen, H. 1991a: Depositional conditions of the Bathonian to Hauterivian Janusfjellet Subgroup, Spitsbergen. Sedimentary Geology 72, 55-78. https://doi.org/10.1016/0037-0738(91)90123-U.

Dypvik, H., Nagy, J., Eikeland, T.A., Backer-Owe, K., Andresen, A., Haremo, P., Bjærke, T., Johansen, H. \& Elverhøi, A. 1991b: The Janusfjellet subgroup (Bathonian to Hauterivian) on central Spitsbergen-a revised lithostratigraphy. Polar Research 9, 21-43. https://doi.org/10.3402/polar.v9i1.6777.

Dypvik, H., Nagy, J. \& Krinsley, D. 1992: Origin of the Myklegardfjellet Bed, a basal Cretaceous marker on Spitsbergen. Polar Research 11, 21-31. https://doi.org/10.3402/polar.v11i1.6714. 
Dörr, N., Lisker, F., Clift, P.D., Carter, A., Gee, D.G., Tebenkov, A.M. \& Spiegel, C. 2012: Late Mesozoic-Cenozoic exhumation history of northern Svalbard and its regional significance: Constraints from apatite fission track analysis. Tectonophysics 514-517, 81-92. https://doi.org/10.1016/j.tecto.2011.10.007.

Edwards, M.B. 1979: Sandstone in Lower Cretaceous Helvetiafjellet Formation, Svalbard: Bearing on Reservoir Potential of the Barents Shelf. American Association of Petroleum Geologists Bulletin 63, 2193-2203.

Elverhøi, A., Antonsen, P., Flood, S.B., Solheim, A. \& Vullstad, A.A. 1988: The physical environment, western Barents Sea 1:500,000. Norsk Polarinstitutt Skrifter 179, 1-32.

Elverhøi, A., Hooke, R.Leb. \& Solheim, A. 1998: Late Cenozoic erosion and sediment yield from the Svalbard-Barents Sea Region: Implications for understanding erosion and glacierized basins. Quaternary Science Reviews 17, 209-241. https://doi.org/10.1016/S0277-3791(97)00070-X.

Embry, A.F. 1991: Mesozoic history of the Arctic islands. In Trettin, H.P. (ed): Geology of the Innuitian Orogen and Arctic Platform of Canada and Greenland, Geological Survey of Canada 3, pp. 369433. https://doi.org/10.1130/DNAG-GNA-E.369.

Embry, A.F. 1993: Crockerland; the northwest source area for the Sverdrup Basin, Canadian Arctic Islands. In Vorren, T.O., Bergsager, E., Dahl-Stamnes, O.A., Holter, E., Johansen, B., Lie, E. \& Lund, T. B. (eds.): Arctic Geology and Petroleum Potential, Proceedings of the Norwegian Petroleum Society Conference 2, Elsevier, pp. 205-216.

Embry, A.F. 1994: Mesozoic stratigraphy of Franz Josef Land Archipelago, Arctic Russia - a literature review. In Thurston, D.K. \& K. Fujita, K. (eds.): Proceeding of the 1992 International Conference on Arctic Margins, United States Mineral Management Service Report 94-0040, pp. 15-20.

Embry, A.F. 1997: Global sequence boundaries of the Triassic and their recognition in the western Canada Sedimentary Basin. Bulletin of Canadian Petroleum Geology 45, 415-433.

Embry, A.F. 2009a: Practical Sequence Stratigraphy. Canadian Society of Petroleum Geologists, 1-79.

Embry, A.F. 2009b: Crockerland - the source area for the Triassic to Middle Jurassic Strata of Northern Axel Heiberg Island, Canadian Arctic Islands. Bulletin of Canadian Petroleum Geology 57, 129-140. https://doi.org/10.2113/gscpgbull.57.2.129.

Embry, A.F. 2011: Petroleum prospectivity of the Triassic-Jurassic succession of Sverdrup Basin, Canadian Arctic Archipelago. Geological Society of London, Memoirs 35, 545-558.

Embry, A. \& Johannessen, E. 1993: T-R sequence stratigraphy, facies analyses and reservoir distribution in the uppermost Triassic and Lower Jurassic succession, western Sverdrup Basin, Arctic Canada. In Vorren, T., Berg-Sager, E., Dahl-Stamnes, O.A., Holter, E., Johansen, B., Lie, E. \& Lund, T.B (eds.): Arctic Geology and Petroleum Potential, Norwegian Petroleum Society, Special Publications 2, pp. 121-146.

Faleide, J.I., Gudlaugsson, S.T. \& Jacquart, G. 1984: Evolution of the western Barents Sea. Marine and Petroleum Geology 1, 123-150. https://doi.org/10.1016/0264-8172(84)90082-5.

Faleide, J.I., Vågnes, E. \& Gudlaugsson, S.T. 1993: Late MesozoicCenozoic evolution of the south-western Barents Sea in a regional rift-shear tectonic setting. Marine and Petroleum Geology 10, 186214. https://doi.org/10.1016/0264-8172(93)90104-Z.

Faleide, J.I., Solheim, A., Fiedler, A., Hjelstuen, B.O., Andersen, E.S. \& Vanneste, K. 1996: Late Cenozoic evolution of the western Barents Sea-Svalbard continental margin. Global Planet Change 12, 53-74. https://doi.org/10.1016/0921-8181(95)00012-7.

Faleide, J.I., Tsikalas, F., Breivik, A.J., Mjelde, R., Ritzmann, O., Engen, Ø., Wilson, J. \& Eldholm, O. 2008: Structure and evolution of the continental margin off Norway and the Barents Sea. Episodes 31, 82-91.
Faleide, J.I., Pease, V., Curtis. M., Klitzke, P., Minakov, A., SheckWenderoth, M., Kostyuchenko, S. \& Zayonchek, A. 2017: Tectonic implications of the lithospheric structure across the Barents and Kara shelves. Geological Society of London, Special Publications 460, 285-314. https://doi.org/10.1144/SP460.18.

Fenies, H \& Faugères, JC. 1998: Facies and geometry of tidal channelfill deposits (Arcachon Lagoon, SW France). Marine Geology 150, 131-148. https://doi.org/10.1016/S0025-3227(98)00049-8.

Fenies. H. \& Tastet, J.P. 1998: Facies and architecture of an estuarine tidal bar (the Trompeloup bar, Gironde Estuary, SW France). Marine Geology 150, 149-169. https://doi.org/10.1016/S0025-3227(98)00059-0.

Fjeldskaar, W. \& Amantov, A. 2017: Effects of glaciations on sedimentary basins. Journal Geodynamics 218, 66-81.

Forman, S., Lubinski, D., Ingólfsson, Ó., Zeeberg, D., Snyder, J.A. \& Matishov, G.G. 2004: A review of postglacial emergence on Svalbard, Franz Josef Land and Novaya Zemlya, northern Eurasia. Quaternary Science Reviews 23, 1391-1434. https://doi.org/10.1016/j.quascirev.2003.12.007.

Gjelberg, J. \& Steel, R.J. 1995: Helvetiafjellet Formation (BarremianAptian) Spitsbergen: characteristics of a transgressive succession. In Steel, R.J., Felt, V.L., Johannessen, E.P. \& Mathieu, C. (eds.): Sequence Stratigraphy on the Northwest European Margin. Norwegian Petroleum Society, Special Publication 5, pp. 571-593. https://doi.org/10.1016/S0928-8937(06)80087-1.

Gjelberg, J., Dreyer, T., Høie, A., Tjelland, T. \& Lilleng, T. 1987: Late Triassic to Mid-Jurassic sandbody development on the Barents and Mid- Norwegian shelf. In Brooks, J. \& Glennie, K.W. (eds.): Petroleum Geology and the Nortwest Europe, Graham and Trotman, London, pp. 1105-1129.

Glørstad-Clark, E., Faleide, J.I., Lundschien, B.A. \& Nystuen, J.P. 2010: Triassic seismic sequence stratigraphy and paleogeography of the western Barents Sea area. Marine and Petroleum Geology 27, 14481475. https://doi.org/10.1016/j.marpetgeo.2010.02.008.

Glørstad-Clark, E., Birkeland, E.P, Nystuen, J.P, Faleide, J.I. \& Midtkandal, I. 2011: Triassic platform-margin deltas in the western Barents Sea. Marine and Petroleum Geology 28, 1294-1314. https://doi.org/10.1016/j.marpetgeo.2011.03.006.

Grantz, A., Hart, P.E. \& Childers, V.A. 2011: Geology and tectonic development of the amerasia and Canada Basins, Arctic Ocean. In Spencer, A.M., Gautier, D., Stoupakova, A., Embry, A. \& Sørensen, K. (eds.): Arctic Petroleum Geology, Geological Society London Memoir 35, pp. 771-799. https://doi.org/10.1144/M35.50.

Grogan, P., Østvedt-Ghazi, A.M., Larssen, G.B., Fotland, B., Nyberg, K., Dahlgren, S. \& Eidvin, T. 1999: Structural elements and petroleum geology of the Norwegian sector of the Barents Sea. In Fleet, A.J. \& Boldy, S.A.R. (eds): Petroleum Geology of Northwest Europe, Proceedings of the 5th Conference, Petroleum Geology Conference Series 5, pp. 247-259. https://doi.org/10.1144/0050247.

Grogan, P., Nyberg, K., Fotland, B., Myklebust, R., Dahlgren, S. \& Riis, F. 2000: Cretaceous Magmatism South and East of Svalbard: Evidence from Seismic Reflection and Magnetic. Polarforschung 68, 25-34.

Grundvåg, S.A. \& Olaussen, S. 2017: Sedimentology of the Lower Cretaceous at Kikutodden and Keilhaufjellet, southern Spitsbergen: implications for an onshore-offshore link. Polar Research 36, 1-20. https://doi.org/10.1080/17518369.2017.1302124.

Grundvåg, S.A., Marin, D., Kairanov, B., Śliwińska, K.K., NøhrHansen, H., Jelby, M. J., Escalona, A. \& Olaussen S. 2017: The Lower Cretaceous succession of the northwestern Barents Shelf: Onshore and offshore correlation. Marine and Petroleum Geology $86,834-857$. https://doi.org/10.1016/j.marpetgeo.2017.06.036.

Gudlaugsson S.T., Faleide J.I., Johansen S.E. \& Breivik, A. 1998: Late Palaeozoic structural development of the south-western Barents Sea. Marine and Petroleum Geology 15, 73-102. https://doi.org/10.1016/S0264-8172(97)00048-2. 
Harland, W.B. 1997: The geology of Svalbard. Geological Society Memoir 17, Geological Society of London, United Kingdom, pp. 525.

Helland-Hansen, W. \& Hampson, G. J. 2009: Trajectory analysis: Concepts and applications. Basin Research 21, 454-483. https://doi.org/10.1111/j.1365-2117.2009.00425.x.

Henriksen, E., Ryseth, A.E., Larssen, G.B., Heide, T., Rønning, K., Sollid, K. \& Stoupakova, A.V. 2011: Tectonostratigraphy of the greater Barents Sea: implications for petroleum systems. Geological Society of London, Memoirs 35, 163-195.

Hess, S., Nagy, J. \& Laursen, G.V. 2014: Benthic foraminifera from the Lower Jurassic transgressive mudstones of the south-western Barents Sea-a possible high latitude expression of the global Pliensbachian-Toarcian turnover? Polar Resesearch 33, 1-11. https://doi.org/10.3402/polar.v33.20206.

Horn, G. 1932: Some geological results of the Norwegian Expedition to Franz Josef Land, 1930. Norwegian Journal of Geology 11, 482-489.

Hurum, J.H., Milàn, J., Hammer, Ø., Midtkandal, I., Amundsen, H. \& Sæther, B. 2006: Tracking polar dinosaurs - new finds from the Lower Cretaceous of Svalbard. Norwegian Journal of Geology 86, 397-402.

Hurum, J.H., Druckenmiller, P.S, Hammer, Ø., Nakrem, H.A. \& Olaussen, S. 2016: The theropod that wasn't - an ornithopod tracksite from the Helvetiafjellet Formation (Lower Cretaceous) of Boltodden, Svalbard. In Kear, B.P., Lindgren, J., Hurum, J.H., Milàn, J. \& Vajda, V. (eds.): Mesozoic Biotas of Scandinavia and its Arctic Territories, Geological Society of London, Special Publications 434, pp. 189-206.

Høy, T. \& Lundschien, B.A. 2011: Triassic deltaic sequences in the northern Barents Sea. In Spencer, A., Embry, A., Gautier, D., Stoupakova, A. \& Sørensen, K. (eds): Arctic Petroleum Geology, Geological Society of London, Memoir 35, pp. 249-260.

Ingolfsson, O., Rognvaldsson, F., Bergsten, H., Hedenas, L., Lemdahl, G., Lirio, J.M. \& Sejrup, H.P. 1995: Late Quaternary glacial and environmental history of Kongsoya, Svalbard. Polar Research 14, 123-139. https://doi.org/10.3402/polar.v14i2.6659.

Jacquin, T., Dardeau, G., Durlet, C., de Graciansky, P.C. \& Hantzpergue, P. 1998: The North Sea Cycle. In de Graciansky, P.C., Hardenbol, J., Jacquin, T. \& Vail, P.R. (eds.): An Overview of 2nd-order Transgressive/Regressive Facies Cycles in Western Europe, Society for Sedimentary Geology, Special Publication 60, pp. 445-466.

Johannessen, E.P. \& Embry, A.F. 1989: Sequence correlation: Upper Triassic to Lower Jurassic succession, Canadian and Norwegian Arctic. In Collinson, J.D. (ed.): Correlation in Hydrocarbon Exploration, Norwegian Petroleum Society, Graham and Trotman, pp. 155-170.

Kairanov, B., Escalona, A., Mordasova, A., Śliwińska, K. \& Suslova, A. 2018: Lower Cretaceous tectonostratigraphic evolution of the northcentral Barents Sea. Journal of Geodynamics 118, 183-198. https://doi.org/10.1016/j.jog.2018.02.009.

Klausen, T.G., Ryseth, A.E., Helland-Hansen, W., Gawthorpe, R. \& Laursen, I. 2015: Regional development and sequence stratigraphy of the Middle to Late Triassic Snadd Formation, Norwegian Barents Sea. Marine and Petroleum Geology 62, 102-122. https://doi.org/10.1016/j.marpetgeo.2015.02.004.

Klausen, T.G., Müller, R., Slama, J. \& Helland-Hansen, W. 2016: Evidence for Late Triassic provenance areas and Early Jurassic sediment supply turnover in the Barents Sea Basin of northern Pangea. Lithosphere 9, 14-28. https://doi.org/10.1130/L556.1.

Klausen, T.G., Torland, J.A., Eide, C.H., Alaei, B., Olaussen, S. \& Chiarella D. 2017a: Clinoform development and topset evolution in a mud-rich delta - the Triassic Kobbe Formation, Norwegian Barents Sea. Sedimentology 65, 1132-1169. https://doi.org/10.1111/sed.12417.

Klausen, T.G., Müller, R., Jiř́, S., Olaussen, S., Rismyhr, B. \& HellandHansen, W. 2017b: Depositional history of a condensed shallow marine succession constrained by $\mathrm{U}-\mathrm{Pb}$ detrital zircon: the Lower to Middle Jurassic Stø Formation of the Barents Sea. Journal of the Geological Society of London 175, 130-145,
Koevoets, M.J., Abay, T.B., Hammer, Ø. \& Olaussen, S. 2016: High resolution organic carbon-isotope stratigraphy of the Middle Jurassic - Lower Cretaceous Agardhfjellet Formation of Central Spitsbergen, Svalbard. Palaeogeography, Palaeoclimatology, Palaeoecology 449, 266-274. https://doi.org/10.1016/j.palaeo.2016.02.029.

Koevoets, M.J., Hammer, Ø., Olaussen S., Senger, K. \& Smelror, M. 2019: Integrating subsurface and outcrop data of the Middle Jurassic to Lower Cretaceous Agardfjellet Formation in central Spitsbergen. Norwegian Journal of Geology. In press.

Krajewski, K.P. 1990: Phosphoritization in a starved shallow shelf environment: the Brentskardhaugen Bed (Toarcian-Bajocian) in Spitsbergen. Polish Polar Research 11,331-334.

Krajewski, K.P. 2004: Carbon and oxygen isotopic survey of diagenetic carbonate deposits in the Agardhfjellet Formation (Upper Jurassic), Spitsbergen: Preliminary results. Polish Polar Research 25, 27-43.

Lane, L.S. 1997: Canada Basin, Aerctic Oceas: Evidence against a rotational origin. Tectonics 16, 363-387. https://doi.org/10.1029/97TC00432.

Larssen, G. B., Dahlgren, S., Eliassen, P.E., Fjæringstad, V., Hanesand, T., Hansen, S., Helland-Hansen, W., Heintz, N., Høy, T., Johannessen, E.P., Nøttvedt, A., Olaussen, S., Riis, F., Rundberg, Y., Rømuld, A. \& Williams, R.W., 1995: Kong Karls Land Ekspedisjonen 1992. Sen trias til tidligkritt geologisk utvikling av Kong Karls Land, nordlige Barentshav. Unpublised internal report. Vol I: 216 pp, Vol II: 20 enclosures.

Larssen, G. B., Helland-Hansen, W., Johannessen, E.P., Nøttvedt, A., Olaussen, S. and Riis, F., 2008: Outcrops on Kong Karls Land, Arctic Norway: a journey to the Norian-Lower Cretaceous in the Northern Barents Sea. IGC33, Oslo 07.08.2008.

Lauritzen, O. \& Ohta, Y. 1984: Geological map of Svalbard, scale 1:500,000, Sheet4G, Nordaustlandet, Norsk Polarinstitutt Skrifter.

Lindstrøm, G. 1900: On Thecocyathus nathorsti n.sp., a Neocomian coral from King Charles Land. Ofvers. Kunglige. Vetenskaps Akademien Førhandlingar 1, 5-12.

Lock, B.E., Pickton, C.A.G., Smith, D.G., Batten, D.J. \& Harland, W.B. 1978: The geology of Edgeøya and Barentsøya, Svalbard. Norsk Polarinstitutt Skrifter 168, 1-64.

Lopatin, B.G., Pavlo, L.G., Orgo, V.V. \& Shkarubo, S. 2001: Tectonic Structure of Novaya Zemlya. Polarforschung 69, 131-135.

Lord, G.S., Solvi, K.H., Ask, M., Mørk, A., Hounslow, M.W. \& Paterson, N.W. 2014: The Hopen Member: A new lithostratigraphic unit on Hopen and equivalent to the Isfjorden Member of Spitsbergen. Norwegian Petroleum Directorate Bulletin 11, 81-96.

Lord G.S., Mørk, M.B.E., Mørk, A. \& Olaussen S. In press. Sedimentology and Petrography of the Svenskøya Formation on Hopen, Svalbard: An analogue to sandstone reservoirs in the Realgrunnen Subgroup. Polar Research.

Lundschien, B.A., Høy, T. \& Mørk, A. 2014: Triassic hydrocarbon potential in the Northern Barents Sea; integrating Svalbard and stratigraphic core data. Norwegian Petroleum Directorate Bulletin $11,3-20$.

Løfaldli, M. 1978: Early Cretaceous foraminifera from the Janusfjellet Formation in Kong Karls Land, eastern Svalbard. Norsk Polarinstitutt Årbok 1977, 345-350.

Løfaldli, M. \& Nagy, J. 1980: Foraminiferal stratigraphy of Jurassic deposits on Kongsøya, Svalbard. Norsk Polarinstitutt Skrifter 172, 63-95.

MacEachern, J.A., Pemberton, S.G., Bann, K.L. \& Gingras, M.K. 2007: Departures from the archetypal ichnofacies: effective recognition of environmental stress in the rock record. In MacEachern, J.A., Bann, K.L., Gingras, M.K. \& Pemberton, S.G. (eds.): Applied Ichnology, Society for Sedimentary Geology Short Course Notes 52, pp. 65-93.

MacEachern, J.A., Pemberton, S.G., Gingras, M.K. \& Bann, K.L. 2010: Ichnology and facies models. In James, N.P. \& Dalrymple, R.W. (eds.): Facies Models 4, Geological Association of Canada, St. John's, Geotext 6, pp. 19-58 
Maher, H.D. 2001: Manifestations of the Cretaceous High Arctic Large Igneous Province in Svalbard. The Journal of Geology 109, 91-104. https://doi.org/10.1086/317960.

Maher H.D., Hays, T., Shuster, R \& Mutrux, J. 2004: Petrography of the Lower Cretaceous sandstones of Spitsbergen. Polar Research 23, 147-165. https://doi.org/10.3402/polar.v23i2.6276.

Marín, D., Escalona, A., Grundvåg, S.A., Olaussen, S., Sandvik, S. \& Śliwińska, K.K. 2017a: Unraveling key controls on the rift-climax to post-rift fill of marine rift basins: insights from 3D seismic analysis of the Lower Cretaceous of the Hammerfest Basin, SW Barents Sea. Basin Research 30, 587-612. https://doi.org/10.1111/bre.12266.

Marín, D., Escalona, A., Sliwinska, K., Nøhr-Hansen, H., Mordasova, A., 2017b: Sequence stratigraphy and lateral variability of lower Cretaceous clinoforms in the SW Barents Sea. American Association of Petroleum Geologists Bulletin 101, 1846-1517.

Metelkin, D.V., Vernikovsky, V.A. \& Matushkin, N.Yu. 2015: Arctida between Rodinia and Pangea. Precambrian Research 259, 114-129. https://doi.org/10.1016/j.precamres.2014.09.013.

Midtkandal, I. \& Nystuen, J.P. 2009: Depositional architecture of a lowgradient ramp shelf in an epicontinental sea: the lower Cretaceous of Svalbard. Basin Research 21, 655-675. https://doi.org/10.1111/j.1365-2117.2009.00399.x.

Midtkandal, I., Nystuen, J.P., Nagy, J. \& Mørk, A. 2008: Lower Cretaceous lithostratigraphy across a regional subaerial unconformity in Spitsbergen: the Rurikfjellet and Helvetiafjellet formations. Norwegian Journal of Geology 88, 287-304.

Midtkandal, I., Svensen, H., Planke, S., Corfu, F., Polteau, S., Torsvik, T.H., Faleide, J.I., Grundvåg, S.A, Selnes, H. \& Olaussen, S. 2016: The Aptian oceanic anoxic event (OAE1a) in Svalbard and the age of the Barremian-Aptian boundary. Palaeogeography, Palaeoclimatology, Palaeoecology 463, 126-135. https://doi.org/10.1016/j.palaeo.2016.09.023.

Minakov, A., Faleide, J.I., Glebovsky, V.Yu. \& Mjelde, R. 2012: Structure and evolution of the northern Barents-Kara Sea continental margin from integrated analysis of potential fields, bathymetry and sparse seismic data. Geophysical Journal International 188, 79-102. https://doi.org/10.1111/j.1365-246X.2011.05258.x.

Mulder, T., Syvitski, J.P.M., Migeon, S., Faugères, J.C. \& Savoye, B. 2003: Marine hyperpycnal flows: Initiation, behaviour and related deposits. A review. Marine and Petroleum Geology 20, 861-882. https://doi.org/10.1016/j.marpetgeo.2003.01.003.

Müller, R., Klausen, T.G., Faleide, J.I., Olaussen, S. Eide, C.H. \& Suslova, A. In review. Linking regional unconformities in the Barents Sea to compression-induced forebulge uplift at the Triassic-Jurassic transition.

Mulrooney, M.J., Rismyhr, B., Yenwongfai, H.D., Leutscher, J., Olaussen, S. \& Braathen, A. 2018: Impacts of small-scale faults on continental to coastal plain deposition: Evidence from the Realgrunnen Subgroup in the Goliat field, southwest Barents Sea, Norway. Marine and Petroleum Geology 95, 276-302.

https://doi.org/10.1016/j.marpetgeo.2018.04.023.

Mørk, A. \& Smelror, M. 2001: Correlation and non-correlation of high order Circum-Arctic Mesozoic sequences. Polarforschung 69, 65-72.

Mørk, A., Knarud, R. \& Worsley, D. 1982: Depositional and diagenetic environments of the Triassic and Lower Jurassic succession of Svalbard. In Embry, A.F. \& Balkwill, H.R. (eds.): Arctic geology and geophysics, Proceedings of the Third International Symposium on Arctic Geology, Canadian Society of Petroleum Geologists, Calgary, pp. 371-398.

Mørk, A., Dallmann, W.K., Dypvik, H., Johannessen, E.P., Larssen, G.B., Nagy, J., Nøttvedt, A., Olaussen, S., Pčelina, T.M. \& Worsley, D. 1999: Mesozoic lithostratigraphy. In Dallmann, W.K. (ed.): Lithostratigraphic lexicon of Svalbard. Review and recommendations for nomenclature use: Upper Palaeozoic to Quaternary bedrock, Norsk Polarinstitutt, Tromsø, pp. 127-214.
Mørk, A., Lord, G.S., Solvi, K.H. \& Dallmann, W.K. 2013: Geological Map of Svalbard, scale 1:100,000, sheet G14G Hopen, Norsk Polarinstitutt Temakart 50.

Nagy, J. \& Basov, V.A. 1998: Revised foraminiferal taxa and biostratigraphy of Bathonian to Ryazanian deposits in Spitsbergen. Micropalaeontology 44, 217-255. https://doi.org/10.2307/1486047.

Nagy, J. \& Berge, S.H. 2008: Micropalaeontological evidence of brackish water conditions during deposition of the Knorringfjellet Formation, Late Triassic-Early Jurassic, Spitsbergen. Polar Research 27, 413-427. https://doi.org/10.1111/j.1751-8369.2007.00038.x.

Nagy, J., Reolid, M. \& Rodriguez-Tovar, F.J. 2009: Foraminiferal morphogroups in dysoxic shelf deposits from the Jurassic of Spitsbergen. Polar Research 28, 214-221. https://doi.org/10.1111/j.1751-8369.2009.00112.x.

Nagy, J., Hess, S., Dypvik, H. \& Bjærke, T. 2011: Marine shelf to paralic biofacies of Upper Triassic to Lower Jurassic deposits in Spitsbergen. Palaeogeography, Palaeoclimatology, Palaeoecology 300, 138-151. https://doi.org/10.1016/j.palaeo.2010.12.018.

Nejbert, K., Krajewski, K.P., Dubińska, E. \& Pécskay, Z. 2011: Dolerites of Svalbard, northwest Barents Sea Shelf: age, tectonic setting and significance for geotectonic interpretation of the High-Arctic Large Igneous Province. Polar Research 30 , 1-24. https://doi.org/10.3402/polar.v30i0.7306.

Nemec, W. 1992: Depositional controls on plant growth and peat accumulation in a braidplain delta environment. Helvetiafjellet Formation (Barremian-Aptian), Svalbard. Geological Society of America Special Papers 267, 209-226. https://doi.org/10.1130/SPE267-p209.

Nikishin, A.M., Ziegler, P.A., Abbott, D., Brunet, M.F \& Cloetingh, S. 2002: Permo-Triassic intraplate magmatism and rifting in Eurasia: implications for mantle plumes and mantle dynamics. Tectonophysics 351, 3-39. https://doi.org/10.1016/S0040-1951(02)00123-3.

Nøttvedt, A., Cecchi, M., Gjelberg, J.G., Kristensen, S.E., Lønøy, A., Rasmussen, A., Rasmussen, E., Skott, P.H. \& Van Veen, P.M. 1993: Svalbard-Barents Sea correlation: a short review. In Vorren, T.O., Bergsager, E., Lie, E. \& Lund, T.B. (eds.): Arctic Geology and Petroleum Potential, Norwegian Petroleum Society Special Publication 2, pp. 363-375. https://doi.org/10.1016/B978-0-444-88943-0.50027-7.

Olaussen, S., Dalland, A., Gloppen, T.G. \& Johannesen, E.P. 1984: Depositional environment and diagenesis of Jurassic reservoir sandstones in the eastern part of the Troms I area. In Spencer, A.M., Johnsen, S.O., Mørk, A., Nysæther, E., Songstad, P. \& Spinnangr, A. (eds.): Petroleum Geology of the North European Margin, Graham and Trotman, London, pp. 61-79.

https://doi.org/10.1007/978-94-009-5626-1_6.

Olaussen S. \& Rismyhr B. 2016. Large scale tectonics as controlling factor of the Upper Triassic to Middle Jurassic basin fills in Svalbard and the Barents Sea. Norwegian Petroleum Society Arctic exploration 2016. Tromsø 4pp

Pang, M. \& Nummedal, D. 1995: Flexural subsidence and basement tectonics of the Cretaceous Western Interior basin, United States. Geology 23, 173-176.

https://doi.org/10.1130/0091-7613(1995)023<0173:FSABTO>2.3.CO;2.

Parsons, J.D., Bush, J.W. \& Syvitski, J.P. 2001: Hyperpycnal plume formation from riverine outflows with small sediment concentrations. Sedimentology 48, 465-478.

https://doi.org/10.1046/j.1365-3091.2001.00384.x.

Paterson, N.W. \& Mangerud, G. 2015: Late Triassic (Carnian-Rhaetian) palynology of Hopen, Svalbard. Review of Palaeobotany and Palynology 220, 98-119.

https://doi.org/10.1016/j.revpalbo.2015.05.001. 
Paterson, N.W., Mangerud G., Cetean, C.G., Mørk, A., Lord G.S., Klausen T.G. \& Mørkved, P.T. 2016: A multidisciplinary biofacies characterisation of the Late Triassic (late Carnian-Rhaetian) Kapp Toscana Group on Hopen, Arctic Norway. Palaeogeography, Palaeoclimatology, Palaeoecology 464, 16-42. https://doi.org/10.1016/j.palaeo.2015.10.035.

Petrov, O.V., Sobolev, N.N., Koren, T., Vasiliev, V.E., Petrov, E.O., Larssen, G.B. \& Smelror, M. 2008a: Palaeozoic and Early Mesozoic evolution of the East Barents and Kara Seas sedimentary basins. Norwegian Journal Geology 88, 227-234.

Petrov, G.A., Ronkin, Yu.L., Maslov A.V., Svyazhina I.A., Rybalka A.V. \& Lepikhina O.P. 2008b: Timing of the onset of collision in the central and northern Urals. Doklady Earth Sciences 422, 1050-1055. https://doi.org/10.1134/S1028334X08070106.

Petrov, O., Morozov, A., Shokalsky, S., Kashubin, S., Artemieva, I.M., Sobolev, N., Petrov, E., Ernst, R., Sergeev, S. \& Smelror, M. 2016: Crustal structure and tectonic model of the Arctic region. EarthScience Reviews 154, 29-71. https://doi.org/10.1016/j.earscirev.2015.11.013.

Pickton, C.A.G., Harland, W.B., Hughes, N.F. \& Smith, D.G. 1979: Mesozoic stratigraphy of eastern Svalbard: a reply. Geological Magazine 116, 55-61. https://doi.org/10.1017/S0016756800042011.

Polteau, S., Planke, S., Faleide, J.I., Svensen, H. \& Myklebust, R. 2010: The Cretaceous high Arctic large igneous province. Geophysical Research Abstracts 12.

Polteau, S., Hendriks, B.W.H., Planke, S., Ganerød, M., Corfu, F., Faleide, J.I., Midtkandal, I., Svensen, H.S. \& Myklebust, R., 2015: The early cretaceous Barents Sea sill complex: distribution, 40Ar/39Ar geochronology, and implications for carbon gas formation. Palaeogeography, Palaeoclimatology, Palaeoecology 441, 83-96. https://doi.org/10.1016/j.palaeo.2015.07.007.

Rawson, P.F. 1982: New Arctocephalitinae (Ammonoidea) from the Middle Jurassic of Kong Karls Land. Geological Magazine 119, 95-100. https://doi.org/10.1017/S0016756800025693.

Reineck, H.E. \& Singh, I.B. 1980: Depositional Sedimentary Environments, second edition. New York, Springer-Verlag, 430 pp. https://doi.org/10.1007/978-3-642-81498-3.

Riis, F., Lundschien, B.A., Høy, T., Mørk, A. \& Mørk, M.B.E. 2008: Evolution of the Triassic shelf in the northern Barents Sea region. Polar Research 27, 318-338. https://doi.org/10.1111/j.1751-8369.2008.00086.x.

Rismyhr, B., Bjærke, T., Olaussen, S., Mulrooney, M.J. \& Senger, K. 2019: Facies, palynostratigraphy and sequence stratigraphy of the Wilhelmøya Sugroup (Upper Triassic-Middle Jurassic) in western central Spitsbergen, Svalbard. Norwegian Journal of Geology. In press.

Ritzmann, O. \& Jokat, W. 2003: Crustal structure of northwestern Svalbard and the adjacent Yermak Plateau: evidence for Oligocene detachment tectonics and non-volcanic breakup. Geophysical Journal International 152, 139-159.

https://doi.org/10.1046/j.1365-246X.2003.01836.x.

Ritzmann O. \& Faleide J.I. 2009: The crust and mantle lithosphere in the Barents Sea/Kara Sea region. Tectonophysics 470, 89-104. https://doi.org/10.1016/j.tecto.2008.06.018.

Ryseth, A. 2014: Sedimentation at the Jurassic-Triassic boundary, south-west Barents Sea. In Martinius, A.W., Ravnås, R., Howell, J.A., Steel, R.J. \& Wonham, J.P. (eds.): From Depositional Systems to Sedimentary Successions on the Norwegian Continental Margin, International Association Sedimentology Special Publication 46, pp. 187-214. https://doi.org/10.1002/9781118920435.ch9.

Rønnevik, H. \& Jacobsen, H.P. 1984; Structural highs and basins in the western Barents Sea. In Spencer, A.M. (ed.): Petroleum Geology of the North European Margin, Proceedings of the North European Margin Symposium (NEMS 83'), Graham \& Trotman, Norwegian Petroleum Directorate, pp. 436.

https://doi.org/10.1007/978-94-009-5626-1_3.

Salvigsen, O. 1981: Radiocarbon dated raised beaches in Kong Karls Land, Svalbard and their consequences for the glacial history of the Barents Sea. Geografiska Annaler 63, 280-291.
Scott, R., Howard, J., Guo, L., Schekoldin, R. \& Pease, V. 2010: Offset and curvature of the Novaya Zemlya fold-and-thrust belt, Arctic Russia. In Vining B.A. \& Pickering S.C. (eds.): Petroleum Geology, From Mature Basins to New Frontiers - Proceedings of the 7th Petroleum Conferences, Geological Society of London, pp. 645-657.

Seldal, J. 2005: Lower Cretaceous: the next target for oil exploration in the barents sea? In Doré, A.G. \& Vining, B.A. (eds.): Petroleum Geology, North-West Europe and Global Perspectives Proceedings of the 6th Petroleum Geology Conference, Geological Society of London 6, pp. 231-240. https://doi.org/10.1144/0060231.

Senger, K., Roy, S., Braathen, A., Buckley, S.J., Bælum, K., Gernigon, L., Mjelde, R., Noormets, R., Ogata, K., Olaussen, S., Planke, S., Ruud, B.O. \& Tveranger, J. 2013: Geometries of doleritic intrusions in central Spitsbergen, Svalbard: an integrated study of an onshore-offshore magmatic province with implications on $\mathrm{CO}_{2}$ sequestration. Norwegian Journal of Geology 93, 143-166.

Senger, K., Planke, S., Polteau, S., Ogata, K. \& Svensen, H. 2014a: Sill emplacement and contact metamorphism in a siliciclastoic reservoir on Svalbard, Arctic Norway. Norwegian Journal of Geology 94, 155-169.

Senger, K., Tveranger, J., Ogata, K., Braathen, A., Planke, S. 2014b: Late Mesozoic magmatism in Svalbard: a review. Earth-Science Reviews 139, 123-144. https://doi.org/10.1016/j.earscirev.2014.09.002.

Serck, C.S., Faleide, J.I., Braathen, A., Kjølhammer, B. \& Escolona, A. 2017: Jurassic to Early Cretaceous basin configuration(s) in the Fingerdjupet Subbasin, SW Barents Sea. Marine and Petroleum Geology 86, 874-891. https://doi.org/10.1016/j.marpetgeo.2017.06.044.

Sigmond, E. 1992: Bedrock map of Norway and adjacent ocean areas, scale 1:3,000,000, Geological Survey of Norway.

Sheldon, N.D. \& Tabor, N.J. 2009: Quantitative paleoenvironmental and paleoclimatic reconstruction using paleosols. Earth-Science Reviews 95, 1-52. https://doi.org/10.1016/j.earscirev.2009.03.004.

Skiold, L.J., van Veen, P.M., Kristensen, S.E. \& Rasmussen, A.R. 1998: Triassic sequence stratigraphy of the southwestern Barents Sea. In de Graciansky, P.C., Hardenbol, J., Jacquin, T. \& Vail, P.J. (eds.): Mesozoic and Cenozoic Sequence Stratigraphy of European Basins. Society for Sedimentary Geology, Society for Sedimentary Geology Special Publication 60, Tulsa, pp. 651-666. https://doi.org/10.2110/pec.98.02.0651.

Smelror, M. 1986: Jurassic and Lower Cretaceous palynomorph assemblages from Cape Flora, Franz Josef Land, Arctic, USSR. Norwegian Journal of Geology 66, 107-119.

Smelror, M. 1988: Bathonian to early Oxfordian dinoflagellate cysts and acritarchs from Kong Karls Land, Svalbard. Review of Palaeobotany and Palynology 56, 275-303. https://doi.org/10.1016/0034-6667(88)90061-9.

Smelror, M. 1994: Jurassic stratigraphy of the western Barents Sea Region: A review. Geobios 17, 441-451. https://doi.org/10.1016/S0016-6995(94)80165-7.

Smelror, M. 2008. Dinosaurs on Svalbard. Det Kongelige Norske Videnskabers Selskab Årbok 2007, 73-77.

Smelror, M. \& Larssen, G.B. 2016: Are there Upper Cretaceous sedimentary rocks preserved on Sørkapp Land, Svalbard? Norwegian Journal of Geology 96, 1-12.

Smelror, M., Mørk, A., Monteil, E., Rutledge, D. \& Leereveld, H. 1998: The Klippfisk Formation-a new lithostratigraphic unit of Lower Cretaceous platform carbonates on the Western Barents Shelf. Polar Research 17, 181-202. https://doi.org/10.1111/j.1751-8369.1998.tb00271.x.

Smelror, M., Petrov, O.V., Larssen, G.B. \& Werner, S. 2009: Geological History of the Barents Sea. Geological Survey of Norway, Trondheim, $134 \mathrm{pp}$.

Smelror, M., Larssen, G.B. Olaussen, S., Rømuld, A. \& Williams, R. 2018: Late Triassic to Early Cretaceous palynostratigraphy of Kong Karls Land, Svalbard, Arctic Norway. Norwegian Journal of Geology 98 
Smith, D.G., Harland, W.B. \& Hughes, N.F. 1975: Geology of Hopen, Svalbard. Geological Magazine 112, 1-112.

https://doi.org/10.1017/S0016756800045544.

Smith, D.G., Harland, W.B., Hughes, N.F. \& Pickton, C.A.G. 1976: The geology of Kong Karls Land, Svalbard. Geological Magazine 113, 193-232. https://doi.org/10.1017/S001675680004320X.

Spencer, A.M., Briskeby, P.I., Christensen, L.D., Foyn, R., Kjolleberg, M., Kvadsheim, E., Knight, I., Rye-Larsen, M. \& Williams, J. 2008: Petroleum geoscience in Norden-exploration, production and organization. Episodes 31, 115-124.

Spencer, A.M., Embry, A.F., Gautier, D.L., Stoupakova, A.V. \& Sørensen, K. 2011: An overview of the petroleum geology of the Arctic. In Spencer, A.M., Embry, A.F., Gautier, D.L., Stoupakova, A.V. \& Sørensen, K. (eds): Arctic Petroleum Geology, Geological Society of London, Memoirs 35, 1-15.

Steel, R.J. \& Worsley, D. 1984: Svalbard's post-Caledonian strata - an atlas of sedimentation patterns and palaeogeographic evolution. In Spencer, A.M. (ed.): Petroleum Geology of the North European Margin, Norwegian Petroleum Society, Graham and Trotman, London, pp. 109-135

Stoupakova, A.V., Henriksen, E., Burlin, Y.K., Larsen, G.B., Milne, J.K., Kiryukhina, T.A., Golynchik, P.O., Bordunov, S.I., Ogarkova, M.P. \& Suslova, A.A. 2011: The geological evolution and hydrocarbon potential of the Barents and Kara shelves. In Spencer, A.M., Embry, A.F., Gautier, D.L., Stoupakova, A.V. \& Sørensen, K. (eds): Arctic Petroleum Geology, Geological Society of London, Memoirs 35, pp. 325-344. https://doi.org/10.1144/M35.21.

Surlyk, F. 2003: The Jurassic of East Greenland: a sedimentary record of thermal subsidence, onset and culmination of rifting. In Ineson, J.R. \& Surlyk, F. (eds): The Jurassic of Denmark and Greenland, Geological Survey of Denmark and Greenland Bulletin 1, pp. 659-722.

Swift, D., Figueiredo, A., Freeland, G. \& Oertel, G. 1983: Hummocky cross-stratification and megaripples: a geological double standard? Journal of Sedimentary Petrology 53, 1295-1317.

Verdenius, J.G. 1978: Valanginian calcareous nannofossil association from Kong Karls Land, eastern Svalbard. Norsk Polarinstitutt Årbok 1977, 350-351.

Vigran, J.O., Mangerud, G., Mørk, A., Worsley, D. \& Hochuli, P.A. 2014: Palynology and geology of the Triassic succession of Svalbard and the Barents Sea. Geological Survey of Norway Special Publication 14, $1-270$.

Visser, M.J. 1980: Neap-spring cycles refl ected in Holocene subtidal large-scale bedform deposits: preliminary note. Geology 8, 543-546. https://doi.org/10.1130/0091-7613(1980)8<543:NCRIHS>2.0.CO;2.

Wignall, P.B. \& Bond, D.P.G. 2008: The end-Triassic and Early Jurassic mass extinction records in the British Isles. Proceedings of the Geologists' Association 119, 73-84. https://doi.org/10.1016/S0016-7878(08)80259-3.

Willis, B.J., Bhattacharya, J.P., Gabel, S.L. \& White, C.D. 1999: Architecture of a tide-influence river delta in the Frontier Formation of central Wyoming. Sedimentology 46, 667-688. https://doi.org/10.1046/j.1365-3091.1999.00239.x.

Walker, K.R., Shanmugam, G. \& Ruppel, S.C. 1983: A model for carbonate to terrigenous clastic sequences. Geological Society of America Bulletin 94, 700-712.

https://doi.org/10.1130/0016-7606(1983)94<700:AMFCTT>2.0.CO;2.

Worsley, D. 1973: The Wilhelmoya Formation - a new lithostratigraphical unit from the Mesozoic of eastern Svalbard. Norsk Polarinstitutt Årbok 1971, 7-16.

Worsley, D. 2008: The post-Caledonian development of Svalbard and the western Barents Sea. Polar Research 27, 298-317. https://doi.org/10.1111/j.1751-8369.2008.00085.x.

Worsley, D. \& Heintz, N. 1977: The stratigraphical significance of a marine vertebrate fauna of Rhaetian age, Kong Karls Land. Norsk Polarinstitutt Årbok 1976, 69-81.
Yang, Y.C., Gingras, M.K., Pemberton, S.G., Dalrymple R.W. 2008: Wave-generated tidal bundles as an indicator of wave-dominated tidal flats. Geology 36, 39-42. https://doi.org/10.1130/G24178A.1.

Zakharov, V.A., Shurygin, B.N., Il'ina, V.I. \& Nikitenko, B.L. 2006: Pliensbachian-Toarcian biotic turnover in north Siberia and the Arctic region. Stratigraphy and Geological Correlation 14, 399-417. https://doi.org/10.1134/S0869593806040046. 
